VILNIUS GEDIMINAS TECHNICAL UNIVERSITY

Mark SENIUT

\title{
DEVELOPMENT OF THE INTELLIGENT TUTORING SYSTEM FOR BUILT ENVIRONMENT
}

DOCTORAL DISSERTATION

TECHNOLOGICAL SCIENCES,

INFORMATICS ENGINEERING (07T)

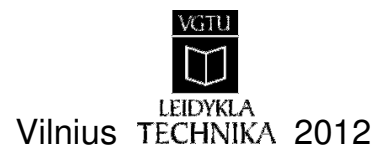


Doctoral dissertation was prepared at Vilnius Gediminas Technical University in 2008-2012.

\section{Scientific Supervisor}

Prof Dr Habil Edmundas Kazimieras ZAVADSKAS (Vilnius Gediminas Technical University, Technological Sciences, Informatics Engineering - 07T).

VGTU leidyklos TECHNIKA 2107-M mokslo literatūros knyga http://leidykla.vgtu.lt

ISBN 978-609-457-425-2

(C) VGTU leidykla TECHNIKA, 2012

(C) Mark Seniut, 2012

markseniut@gmail.com 
VILNIAUS GEDIMINO TECHNIKOS UNIVERSITETAS

Mark SENIUT

\section{INTELEKTINĖS MOKYMO SISTEMOS, SKIRTOS STATINIAMS IR JŲ APLINKAI, KÜRIMAS}

DAKTARO DISERTACIJA

TECHNOLOGIJOS MOKSLAI,

INFORMATIKOS INŽINERIJA (07T)

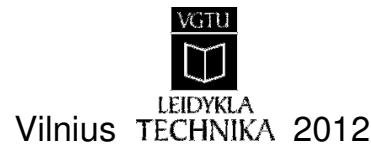


Disertacija rengta 2008-2012 metais Vilniaus Gedimino technikos universitete.

\section{Mokslinis vadovas}

prof. habil. dr. Edmundas Kazimieras ZAVADSKAS (Vilniaus Gedimino technikos universitetas, technologijos mokslai, informatikos inžinerija - 07T). 


\section{Abstract}

The dissertation examines the problem of students' training and testing. To solve the problem, new model, algorithms and system have been developed and adapted. The developed system enables organizing of individual and group training and self-control process. Integrated intelligent search subsystem helps to develop the study plan for the themes of interest. The system continuously monitors the user and can respond to his failure.

The developed built environment computer learning subsystem performs practical calculations to assess the built environment projects. The main problem solved by development of the subsystem is reduction of time needed for users to create their own systems. Knowledge database created during the system development can be a good source of knowledge for new or similar projects evaluations. Calculation results can be saved for further research or shared with other users of the system.

The dissertation consists of Introduction, 4 Chapters, Conclusions, References, and List of Author's Publications.

The introduction reveals the investigated problem, importance of the thesis and the object of research and describes the purpose and tasks of the dissertation, research methodology, scientific novelty, the practical significance of results examined in the dissertation and defended statements. The introduction ends in presenting the author's publications on the subject of the defended dissertation, offering the material of made presentations in conferences and defining the structure of the dissertation.

Chapter 1 revises scientific literature. The world experience in development of intelligent tutoring systems is analyzed. Also definitions of intelligent tutoring systems and the built environment are provided.

Chapter 2 overviews the multi objective assessment methods and discusses their integration into the overall system.

Chapter 3 presents the model of intelligent tutoring system for built environment. All parts off developed system are reviewed including methods, submodels, algorithms and databases.

Chapter 4 presents three real life case studies that show practical application results of the created system.

12 articles focusing on the subject of the discussed dissertation are published: 7 articles - in the Thomson ISI Web of Science register and 5 articles in the proceedings in Thomson ISI data base. Patent "Electronic information retrieval system and method" on behalf of VGTU was acquired. Patent No: LT 5673. 


\section{Reziumè}

Disertacijoje nagrinejjama studentų mokymo ir testavimo problema. Problemai spręsti buvo sukurti ir pritaikyti nauji modeliai, algoritmai ir sistema. Sukurta sistema leidžia organizuoti individualų ir grupini mokymo ir savikontrolès procesą. Integruota intelektinė paieškos posistemè leidžia sudaryti dominančios tematikos mokymosi planą. Sistema nuolat stebi vartotoją ir gali reaguoti i jo mokymosi nesèkmes.

Sukurta kompiuterinio mokymo posistemè, skirta statiniams ir jų aplinkai, atlieka praktinį statinių ir jų aplinkos projektų vertinimą. Pagrindinè išspręsta problema kuriant posistemę yra laiko sąnaudų mažinimas, kurių reikètų kuriant

atskiras sistemas. Žinių bazè, kuri buvo sudaryta kuriant sistemą gali tapti pagrindu naujiems ar panašiems projektams vertinti. Skaičiavimo rezultatai gali būti išsaugoti tolesniems tyrimams atlikti arba jais galima dalintis su kitais sistemos vartotojais.

Disertaciją sudaro ịvadas, keturi skyriai, rezultatų apibendrinimas, naudotos literatūros sąrašas ir autoriaus publikacijų disertacijos tema sąrašas.

Ivade aptariama tiriamoji problema, darbo aktualumas, aprašomas tyrimu objektas, formuluojamas darbo tikslas bei uždaviniai, aprašoma tyrimų metodi$\mathrm{ka}$, darbo mokslinis naujumas, darbo rezultatų praktinè reikšmė, ginamieji teiginiai. Ivado pabaigoje pristatomos disertacijos tema autoriaus paskelbtos publikacijos bei pranešimai konferencijose ir disertacijos struktūra.

Pirmame disertacijos skyriuje atliekama literatūros apžvalga. Nagrinėjama pasauline patirtis kuriant intelektines mokymo sistemas. Taip pat pateikiami intelektinès mokymo sistemos bei statinių ir jų aplinkos apibrèžimai.

Antrame skyriuje apžvelgiami daugiatiksliai vertinimo metodai, jų adaptavimo galimybès kuriamai intelektinei mokymo sistemai, skirtai statiniams ir jų aplinkai.

Trečiame skyriuje pristatomas intelektinès mokymo sistemos, skirtos statiniams ir jų aplinkai, modelis. Išsamiai nagrinejjami sistemos elementai - metodai, submodeliai, algoritmai ir duomenų bazès.

Ketvirtame skyriuje atliekama trijų atvejų analizè, parodanti praktinius sukurtos sistemos taikymo rezultatus.

Disertacijos tema paskelbta 12 mokslinių straipsnių: 7 - mokslo leidiniuose, įtrauktuose i Thomson ISI Web of Science sąrašą; 5 - konferencijų medžiagose, referuotose Thomson ISI duomenų bazeje. Taip pat VGTU vardu buvo gautas patentas „Elektroninès informacijos paieškos būdas ir sistema“. Patento Nr.: LT 5673. 
Notations

\section{Symbols}

$a_{j}-$ the $j^{\text {th }}$ alternative;

$d_{i j}$ - the normalized weighted alternative value;

$m$ - the number of attributes;

$n$ - the number of alternatives;

$N_{j}$ - the utility degree of the $j^{\text {th }}$ alternative (COPRAS method);

$q_{i}$ - the significance (weight) of the $i^{\text {th }}$ criterion;

$Q_{j}$ - the efficiency index of the $j^{\text {th }}$ alternative (COPRAS method);

$S$ - the total square deviation;

$S_{+j}$ - the sum of maximizing attributes (COPRAS method);

$S_{-j}-$ the sum of minimizing attributes (COPRAS method);

$S_{-\min }-$ the minimal sum of minimizing attributes (COPRAS method);

$x_{i j}$ - the attribute value of the $j^{\text {th }}$ alternative. 


\section{Abbreviations}

AHP - Analytic Hierarchy Process;

ARAS - Additional Ratio Assessment;

COPRAS - A Method of Multiple Criteria Complex Proportional Evaluation;

DSS - Decision Support System;

ITSBE - Intelligent Tutoring System for Built Environment;

ITMOAS - Intelligent Tutoring and Multi Objective Assessment System;

KDSS-CPM - Knowledge Based Decision Support System for Construction

Projects Management;

MOA - Multi Objective Assessment;

MOAS - Multi Objective Assessment Subsystem;

SAW - Simple Additive Weighting;

TOPSIS - Technique for Order Preference by Similarity to an Ideal Solution. 


\section{Contents}

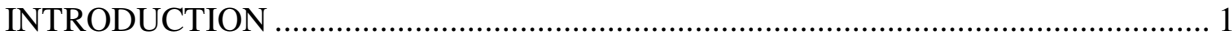

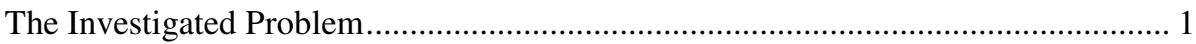

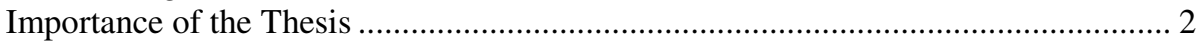

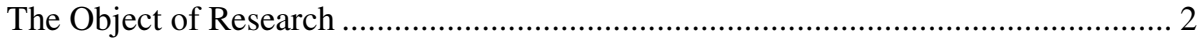

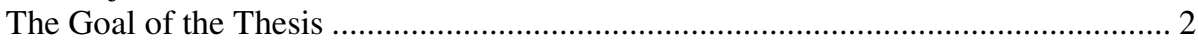

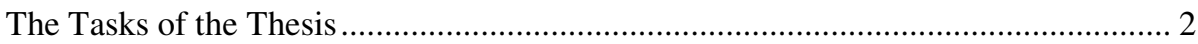

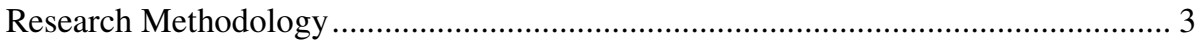

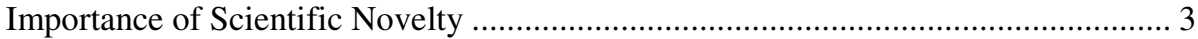

Practical Significance of Achieved Results ................................................................ 3

The Defended Statements.................................................................................... 3

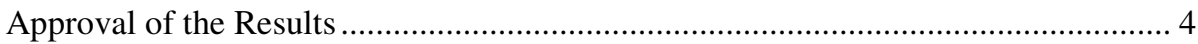

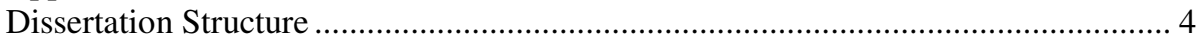

1. REVIEW OF INTELLIGENT TUTORING SYSTEMS FOR BUILT

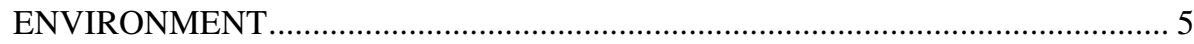

1.1. Introduction to Intelligent Tutoring Systems ................................................... 5

1.2. Intelligent Tutoring System: the Scope and Definition ........................................ 6

1.3. Built Environment: the Scope and Definition ................................................. 8

1.4. Review of Decision Support Systems........................................................... 14

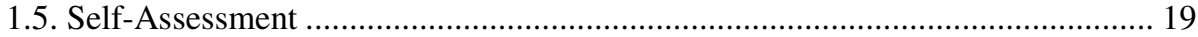

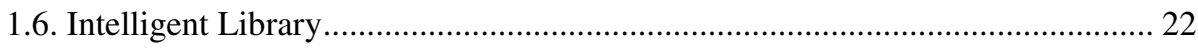

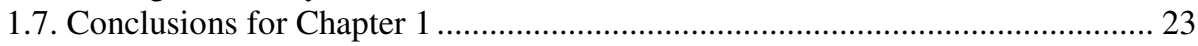


2. MULTI OBJECTIVE ASSESSMENT METHODS FOR INTELLIGENT

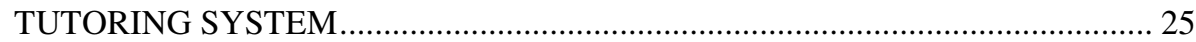

2.1. Review of Multi Objective Assessment Methods.............................................. 25

2.2. A Method of Multiple Criteria Complex Proportional Evaluation Adopted for the Intelligent Tutoring System for Built Environment ........................................ 28

2.3. The Method of Multiple Criteria Multivariant Design Adopted for the Intelligent Tutoring System for Built Environment .......................................................... 32

2.4. A Method of Defining the Utility and Market Value of a Property Adopted for the Intelligent Tutoring System for Built Environment ..................................... 38

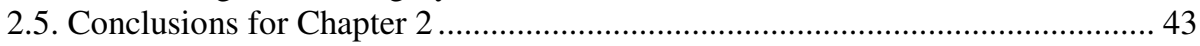

3. INTELLIGENT TUTORING SYSTEM FOR BUILT ENVIRONMENT ................. 45

3.1. Composition of Intelligent Tutoring System for Built Environment ................... 45

3.1.1. Expert Knowledge Subsystem Submodel ................................................. 47

3.1.2. Student Subsystem Submodel................................................................ 53

3.1.3. Tutoring Subsystem Submodel ............................................................... 59

3.1.4. Built Environment Computer Learning Subsystem Submodel .................. 64

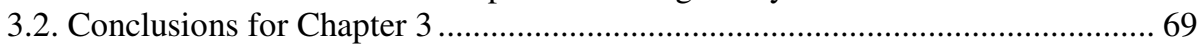

4. PRACTICAL IMPLEMENTATION OF INTELLIGENT TUTORING SYSTEM

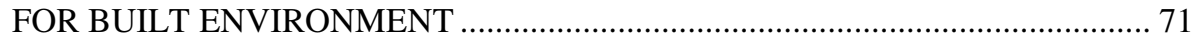

4.1. Case Study of Students' Learning Process by Using Intelligent Library and

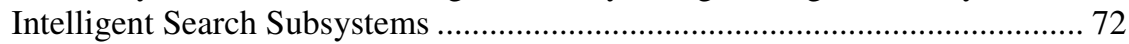

4.2. Case Study of Students' Self-Tests and Examination Process by Using Intelligent

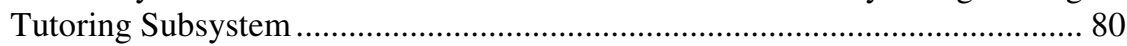

4.3. Case Study of Evaluation of Built Environment Projects' Alternatives ............. 87

4.4. Conclusions for Chapter 4 ................................................................................. 99

GENERAL CONCLUSIONS ........................................................................... 101

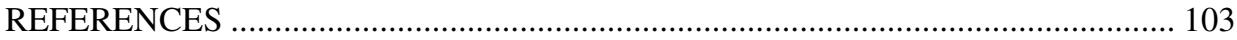

THE LIST OF SCIENTIFIC AUTHOR'S PUBLICATIONS ON THE SUBJECT OF

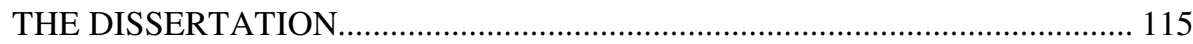




\section{Turinys}

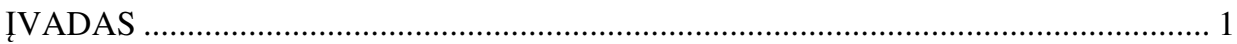

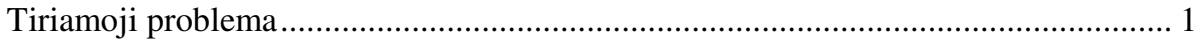

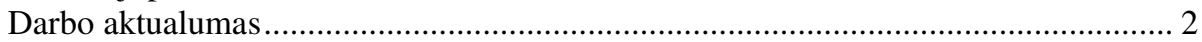

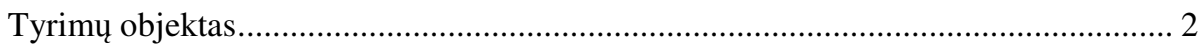

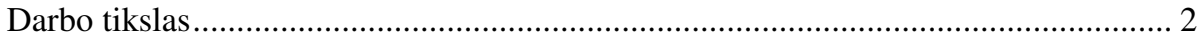

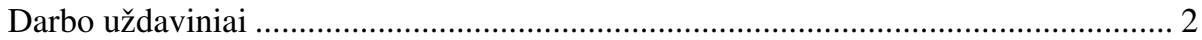

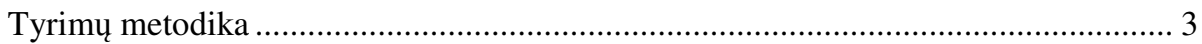

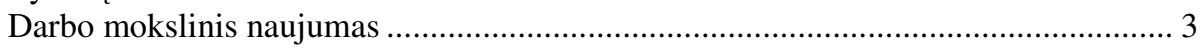

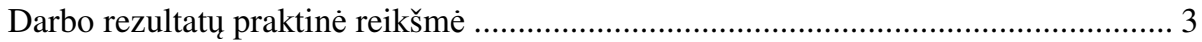

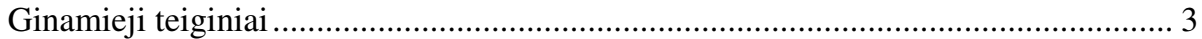

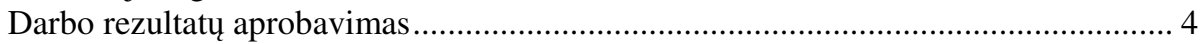

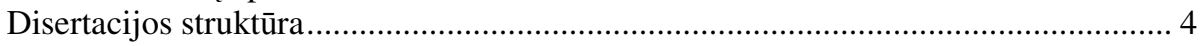

1. INTELEKTINIŲ MOKYMO SISTEMŲ, STATINIŲ IR JŲ APLINKOS SRITYJE,

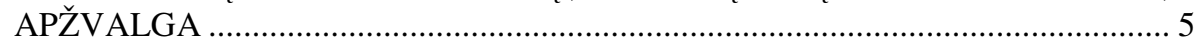

1.1. İvadas ị intelektines mokymo sistemas................................................................ 5

1.2. Intelektinès mokymo sistemos samprata ir apibrèžimas....................................... 6

1.3. Statinių ir jų aplinkos samprata ir apibrèžimas.................................................. 8

1.4. Sprendimų paramos sistemų apžvalga ............................................................ 14

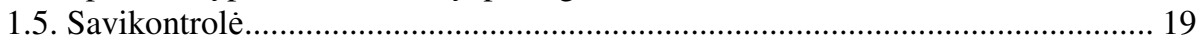

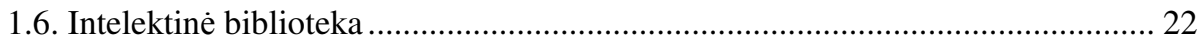

1.7. Pirmojo skyriaus išvados ....................................................................... 23 


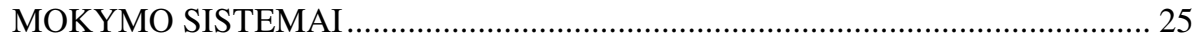

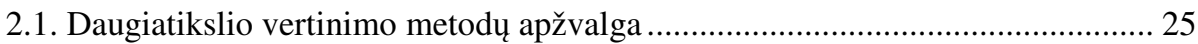

2.2. Daugiakriterinio kompleksinio proporcinio vertinimo metodas, pritaikytas intelektinei mokymo sistemai, skirtai statiniams ir jų aplinkai........................ 28

2.3. Daugiavariantinio projektavimo metodas, pritaikytas intelektinei mokymo sistemai skirtai, statiniams ir jų aplinkai ........................................................ 32

2.4. Naudingumo laipsnio ir nekilnojamojo turto rinkos vertès nustatymo metodas, pritaikytas intelektinei mokymo sistemai, skirtai statiniams ir jų aplinkai ....... 38

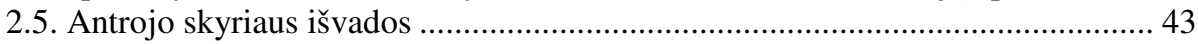

3. INTELEKTINE MOKYMO SISTEMA, SKIRTA STATINIAMS IR JŲ

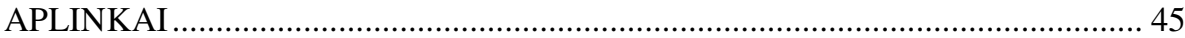

3.1. Intelektinès mokymo sistemos, skirtos statiniams ir jų aplinkai, sandara .......... 45

3.1.1. Ekspertinès žinių posistemès submodelis ................................................ 47

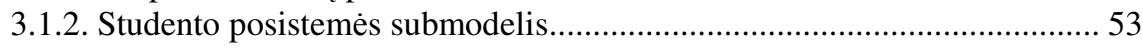

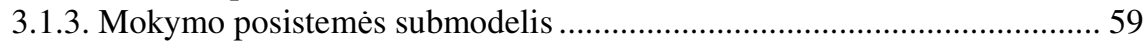

3.1.4. Statinių ir jų aplinkos kompiuterinio mokymo posistemès submodelis.... 64

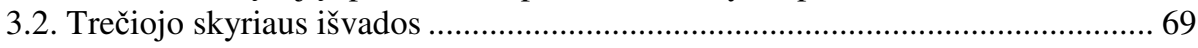

4. INTELEKTINĖS MOKYMO SISTEMOS, SKIRTOS STATINIAMS IR JŲ

APLINKAI, PRAKTINIS TAIKYMAS

4.1. Studentų mokymo proceso, taikant intelektinès bibliotekos ir intelektinès

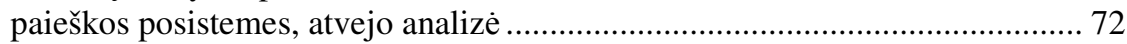

4.2. Studentų savikontrolès testų ir egzaminavimo proceso, taikant intelektinio

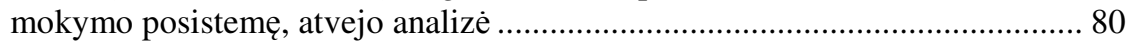

4.3. Statinių ịvertinant jų aplinką projektų alternatyvų vertinimo atvejo analizé ...... 87

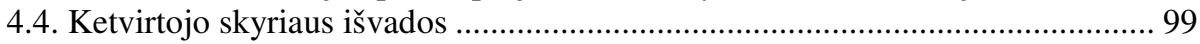

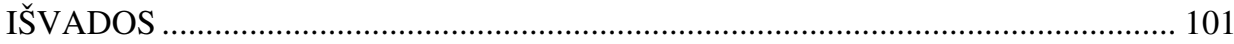

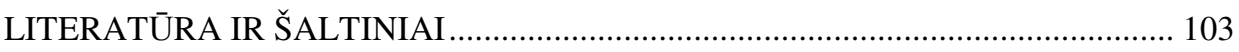

AUTORIAUS PUBLIKACIJŲ DISERTACIJOS TEMA SĄRAŠAS ......................... 115 


\section{Introduction}

\section{The Investigated Problem}

The investigation problem is to determinate the possibility to use up to date intelligent tutoring model in real life student's learning process and to adopt it for the field of built environment. Currently there are many systems that ensure the training process; indeed they don't integrate all the elements to ensure a complete learning process from the initial assessment of knowledge to practical applications. Traditionally, student seeking to gain knowledge in the field of the built environment has to monitor his own academic performance and only during intermediate assessment he is able to evaluate his knowledge. In order to solve this problem, the new system is needed to be developed, able not only to present course materials but also to assess the student's initial level of knowledge and learning efficiency. Practical knowledge application is the essential condition for consolidation of knowledge, for that reason system is needed allowing the management of the built environment projects' evaluations through the best world experience templates. Currently it is a slow and tedious process of using the Excel type programs.

Nowadays personalized training and testing problem is also important. In order to improve the quality of tutoring, the next generation of the systems should take into account a number of personalized parameters (curiosity, stress 
and preferred learning difficulty levels) that are appropriate for assessment and can be adapted in order to increase absorption of knowledge.

\section{Importance of the Thesis}

Recently the knowledge and information flows reached unprecedented heights so far and this situation demands new methods to be developed to allow arranging priority of tutoring better. Lifelong learning concept provides continuous updating of the existing knowledge and ability to get the new one. The next generation tutoring systems should not only be able to provide study material, but also take into account individual student's needs. Special attention is given to the field of build environment and for this purpose specialized expert knowledge base and computer learning system is developed.

\section{The Object of Research}

The main object of research is intelligent tutoring process adapted for the field of built environment.

\section{The Goal of the Thesis}

The main goal of the thesis is to develop the Intelligent Tutoring System for Built Environment model and system.

\section{The Tasks of the Thesis}

In order to reach the goal, the following tasks must be solved:

1. To review research studies of scientists from various countries in the field of the intelligent tutoring systems with special emphasis on the field of built environment.

2. To develop methods for adaptive and personalized learning and testing process.

3. To develop personalized information gathering method and subsystem.

4. To develop methods that allow to perform homeworks, course projects and final works in the field of built environment. 


\section{Research Methodology}

Following algorithms and methods were used during research process: comparative analysis of scientific literature, experimental method, multi objective assessment methods, comparative analysis, knowledge reuse and transformation, research generalization, logic and synthesis methods.

\section{Importance of Scientific Novelty}

Preparation of the thesis revealed the following new results:

1. A new Intelligent Tutoring System for Built Environment model and system was developed and practically applied.

2. Methods for adaptive and personalized learning and testing process were developed and practically applied.

3. Personalized information gathering method and subsystem was developed and practically applied.

4. Methods that allow to perform homeworks, course projects and final works in the field of built environment were developed and practically applied.

\section{Practical Significance of Achieved Results}

The created Intelligent Tutoring System for Built Environment (ITSBE) can be used in learning process. Created ITSBE can be reused in different fields where tutoring is needed. Part of created subsystems and algorithms were implemented in real life projects: IDES-EDU, BELL CURVE, LARGE, EURASIA.

\section{The defended statements}

1. Extended Intelligent Tutoring System model can be successfully used for learning process in the field of built environment.

2. Proposed Intelligent Learning System for Built Environment is able to cover all stages of learning process from primary knowledge assessment to practical knowledge application. 


\section{Approval of the Results}

The main statements of the dissertation were published in 12 scientific articles: 7 with Science Citation Index Expanded (accessed via Web of Science) (Kaklauskas et al. 2010a, 2011a, 2012, 2013; Kanapeckienè et al. 2010; Tupènaitè et al. 2010; Urbanavičienè et al. 2009) and 5 - in the proceedings in Thomson ISI database (Kaklauskas et al. 2007b, 2008c, 2009a, 2009b; Zavadskas et al. 2008c), 1 Lithuanian patent No: LT 5673 on behalf of VGTU was acquired.

\section{Dissertation Structure}

The dissertation consists of Introduction, 4 Chapters, Conclusions, References, List of Publications. The structure of the dissertation is presented in Figure 1.

The volume of the dissertation is 117 pages, 26 numbered formulas are used, 73 figures and 22 tables. 140 literature sources have been used while writing the dissertation.

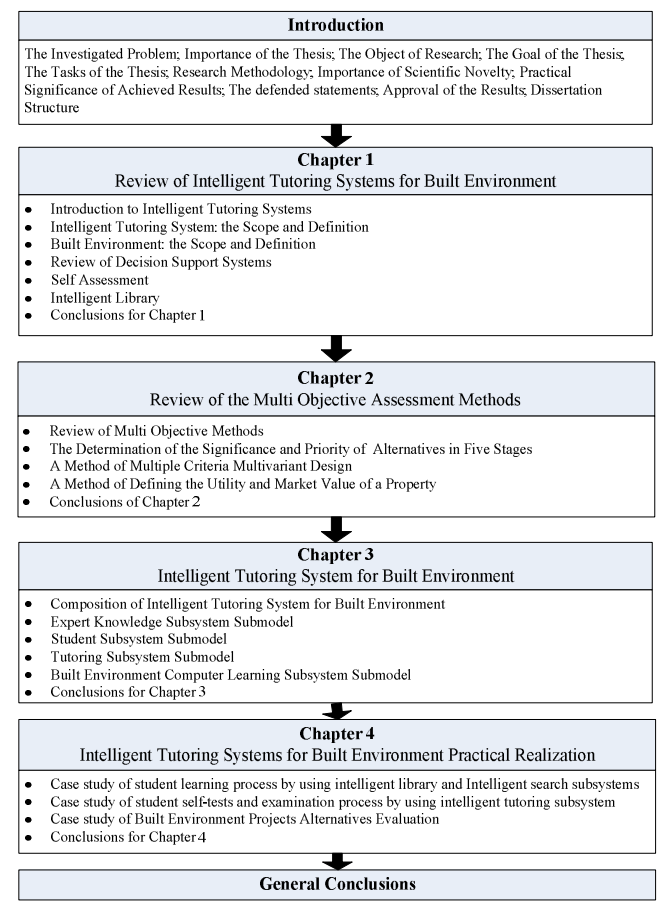

Fig. 1. The structure of the doctoral thesis 


\section{1}

\section{Review of Intelligent Tutoring Systems for Built Environment}

In this chapter the scope and definitions of the intelligent tutoring system and the built environment are presented. Up to date models and systems in this field are described.

\subsection{Introduction to Intelligent Tutoring Systems}

In our days it is hardly to find place where computer based learning system cannot be found. A lot of scientists are working on new methods and algorithms for new Intelligent Tutoring Systems (further - ITSs). Tutoring systems use personal computers and mobile devices to give additional opportunities for online education, giving students not only teaching place freedom, but additionally leading them through all day in this way providing additional information for system.

Intelligent Tutoring Systems extend traditional content-delivery computerised learning systems by adding intelligence to improve the effectiveness of a learner's experience (Brusilovsky and Peylo 2003). This normally involves personalised tutoring by using factors such as learner's knowledge, emotion or 
learning style to alter the sequence and style of learning material. Students' emotions have been proven to influence cognitive processes, motivation and performance (Pekrun et al. 2007). Traditionally ITSs adapt to existing student's knowledge but more recently factors that affect learner have been incorporated, such as emotion (Ammar et al. 2010), personality (Leontidis and Halatsis 2009) and learning style (Popescu 2010).

An important form of student-tutor interaction is feedback (Gutierrez and Atkinson 2011). Negative feedback can be provided by the tutor in response to students mistakes. An effective use of negative feedback can help the student to correct a mistake and prevent him/her from repeating the same or a similar mistake again, effectively providing a learning opportunity to the student.

ITS enables students to practice their skills by carrying out tasks within highly interactive tutoring environments. Unlike other computer-based training technologies, ITSs assess each learner's actions within these interactive environments and develop a model of their knowledge, skills, and expertise. Based on collected learners' data system provides explanations, hints, examples, and practice problems as needed.

\subsection{Intelligent Tutoring System: the Scope and Definition}

The popularity of intelligent tutoring systems is increasing since they were discovered in the sixth decade of the twentieth century as it shows the increasing amount of scientific publications in globally recognized journals and scientific conferences (Tong and Angelides 2000; Hatzilygeroudis and Prentzas 2004; Litman and Forbes-Riley 2006; Stankov et al. 2008; Mao and Li 2010; Günel and Aşliyan 2010; Escudero and Fuentes 2010; D'Mello et al. 2012; Ben Ammar et al. 2010; Sarrafzadeh et al. 2008; Siemer and Angelides 1998; Anderson 2012; Jeremić et al. 2012).

Supporters of artificial intelligence as Allen Newell (Newell 1956), John McCarthy (McCarthy 1959), Marvin Minsky (Minsky 1981) and Alan Turing (Kapetanios 2008) thought that new faster computers could think as humans and act independently or following the instructions (Urban-Lurain 2010). After the Second World War variety of military industry technologies were developed in order to win the Cold War. Systems having artificial intelligence could help. At the same time the problem how to educate and to prepare for work specialists in military education institutions was being solved (Urban-Lurain 2010). In this way computer assisted instructional systems appeared. These systems were dedicated to specialized knowledge areas and were able to observe the accuracy of answers and overall progress of student (Uhr 1969). 
The main problem in creating of tutoring systems was high time and equipment consumption. These systems didn't evaluate learning process by itself as well as knowledge absorption process (Suppes 1967; Uhr 1969).

Sleeman and Brown (1982) in their review of tutoring systems were first who used the term "Intelligent tutoring system". They classified the existing ITSs as being computer-based, problem-solving monitors, coaches, laboratory instructors, and consultants (Urban-Lurain 2010). When the recognized ITS model started to form, the domain of its elements appeared (Nwana 1990) (Fig. $1.1)$.

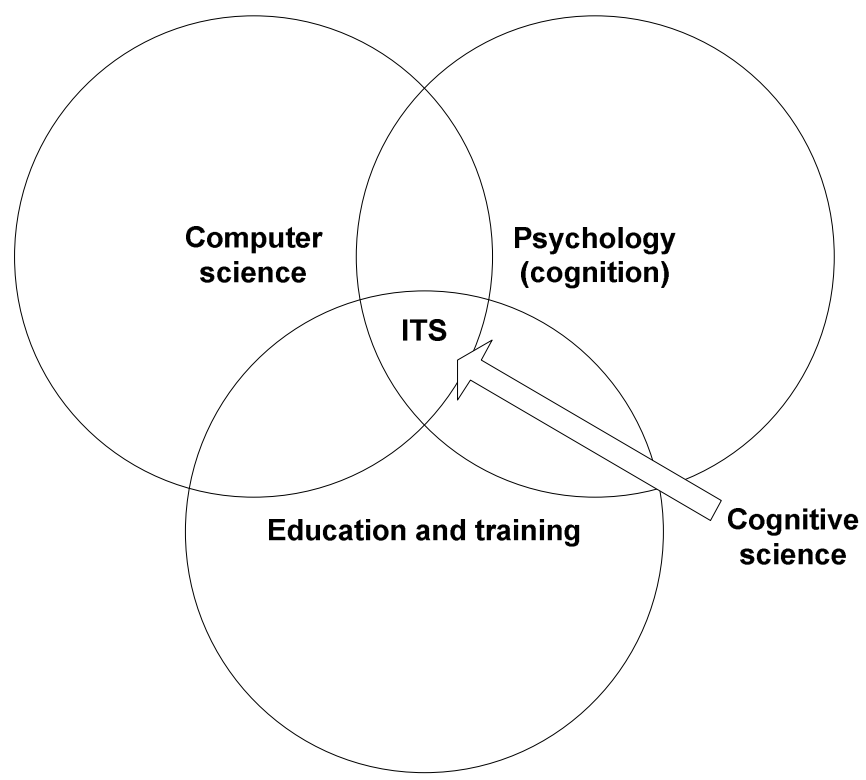

Fig. 1.1. Intelligent tutoring system domain (Nwana 1990)

The key to success was conjunction of three disciplines. Famous psychologists of this period as John Anderson joined this area in order apply their methods in ITS systems (Nwana 1990). Nwana (1990) in his review provided wholly designed ITS architecture which is the basis for many modern systems (see Fig. 1.2).

Association for the Advancement of Artificial Intelligence (AAAI) defined ITS as: "Intelligent tutoring system is educational software containing an artificial intelligence component. The software tracks students' work, tailoring feedback and hints along the way. 


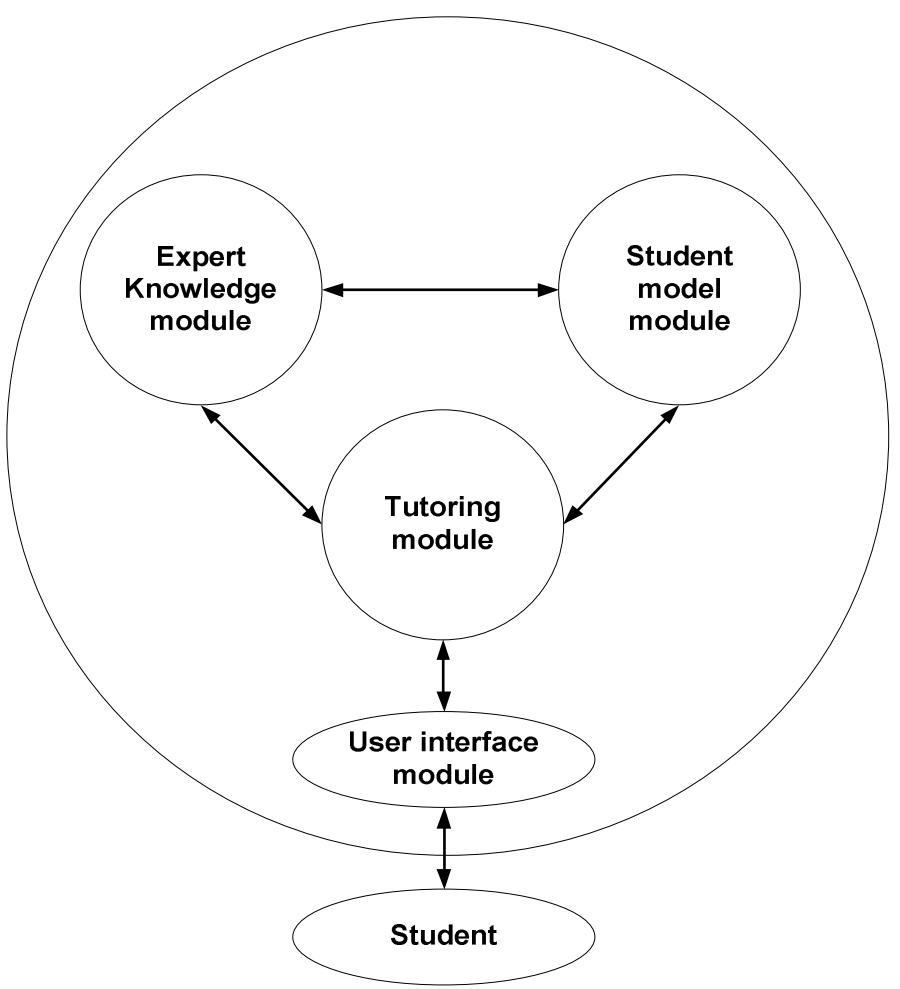

Fig. 1.2. General intelligent tutoring system architecture (Nwana 1990)

By collecting information on a particular student's performance, the software can make inferences about strengths and weaknesses, and can suggest additional work".

\subsection{Built Environment: the Scope and Definition}

Research shows that various scientists have achieved deep insights into different and very important areas of intelligent built environments: structures and materials (Barlow 1969), smart streets (Broderick 2006), smart locks (Collinson 1995), dust (Essex 2003), lighting (Guillemin 2001) and heating (Kummert et al. 2001), intelligent tutoring system (Kaklauskas et al. 2006e), clothing (Lam Po Tang and Stylios 2006), health (Kohnle and Wolf 2007), multimedia service systems (Park et al. 2005), materials (Schacht 2004), antenna (Staedter 2003), energy (Wood and Newborough 2007), evaluation of the intelligent building systems (Wong et al. 2008), modelling temperatures (Ríos-Moreno et al. 2007), multiple 
criteria lifespan energy efficiency assessments (Chen et al. 2006), intelligent mechanical systems (Nishioka et al. 2000), total sustainability in built environments (Kua and Lee 2002), renewable building energy systems (Omer 2008), comparative impact of passive design strategies and active features in hot climates (Ochoa and Capeluto 2008), evaluation of intelligent buildings based on the level of service system integrations (Arkin and Paciuk 1997), standard communication infrastructures (Bushby 1997), voice recognition technology, sensors, and user interface improvements.

There is a growing demand for various above-mentioned solutions of intelligent built environments and studies are being performed in this area. For example, Chen et al. (2006) present a multiple criteria decision-making model for lifespan energy efficiency assessments of intelligent buildings. Nishioka et al. (2000) describe the measurements and evaluation of indoor thermal environments in a large domed stadium. Omer (2008) analyses renewable building energy systems and passive human comfort solutions. Ochoa and Capeluto (2008) describe the comparative impact of passive design strategies and their active features in a hot climate. Kua and Lee (2002) propose a methodology for the promotion of total sustainability in a built environment. According to authors, barriers to the promotion and acceptance of intelligent buildings, and even practices, can generally be grouped as being caused by the lack of: financial resources and confidence to use new and "untested" technologies; professional capacity to incorporate and manage intelligent technologies; knowledge of developers and owners about the environmental impact of inefficient buildings; and information on opportunities granted by intelligent technologies. Authors believe that in order to overcome these barriers, different forms of information should be created and shared among the concerned parties, i.e. architects, building scientists, engineers, conservators, material and equipment suppliers, manufacturers, service and maintenance professionals, marketing professionals, advertising agencies, project developers, owners, and policy-makers.

Several scientists are involved in the modelling of different elements of an intelligent built environment. Ríos-Moreno et al. (2007) are modelling temperature in intelligent buildings by means of autoregressive models. Outside air temperature, global solar radiation flux, outside air relative humidity and air velocity were used as the input variables. Only a few researchers are trying to perform an integrated analysis of an intelligent built environment. For example, Wong et al. (2008) promote and enhance the understanding of key intelligent indicators, and set the foundation for a systematic framework which can be used for appraising the system intelligence of various intelligent building systems. The key intelligent indicators provide developers and building stakeholders with a consolidated inclusive tool for the system intelligence evaluation of the proposed components in design configurations. 
An overview of literature (completed by Wong et al. 2005) related to intelligent building research and indicates that previous research efforts dealt mainly with three research streams, including advanced/innovative technology, performance evaluation methodologies and investment evaluation analysis. According to Wong et al. (2005) there is a growing demand for tools to support intelligent decision-making for building investments. Wong et al. (2005) believe that despite the above-mentioned three research streams there is still a lack of a generally accepted tool for supporting intelligent decision-making for building investments.

It must be noted that researchers from various countries engaged in the analysis of intelligent built environment do not consider an intelligent built environment, the parties involved in its design and implementation, as well as the micro and macro environments that make a particular impact on the intelligent built environment.

The methods and models developed by many authors do not analyse the stakeholder groups (architects, building scientists, engineers, conservators, material and equipment suppliers, manufacturers, service, maintenance professionals, marketing professionals, advertising agencies, project developers, owners, policy-makers), the intelligent built environment and the influencing micro and macro factors (social, economic, technological, natural) as an integrated whole. All around the world, only separate elements of built environment were analysed and evaluated in one form or another (structures and materials (Barton 1997), smart streets (Broderick 2006), smart locks (Collinson 1995), lighting (Guillemin and Morel 2001) and heating (Kummert et al. 2001), intelligent tutoring system (Kaklauskas et al. 1998, 2006e), clothing (Lam Po Tang and Stylios 2006), health (Kohnle and Wolff 2007; Kleinberger et al. 2007), multimedia service systems (Park et al. 2005), energy (Wood and Newborough 2007; Nick and Becker 2007), infrastructures (Bushby 1997), etc.) considering perspectives of different stakeholders. Besides, the global practice has not yet seen scientists making attempts on electronic development of possible alternatives of intelligent built environment, their assessment is based on numerous criteria and selection of the most rational variants for certain stakeholders.

A complex analysis of the above-mentioned research objects was made with the help of new methods for completing a multiple criteria project analysis and was specially developed by Kaklauskas et al. (2010b) for this purpose.

The formalized Model for Complex Analysis of Intelligent Built Environment and Multiple Criteria Decision Support System of Intelligent Built Environment developed by Kaklauskas et al. (2010b) shows how changes in the project alternatives and the extent to which the goals of various stakeholders are satisfied cause respective changes in the value and utility degree of a project (see Fig. 1.3). 


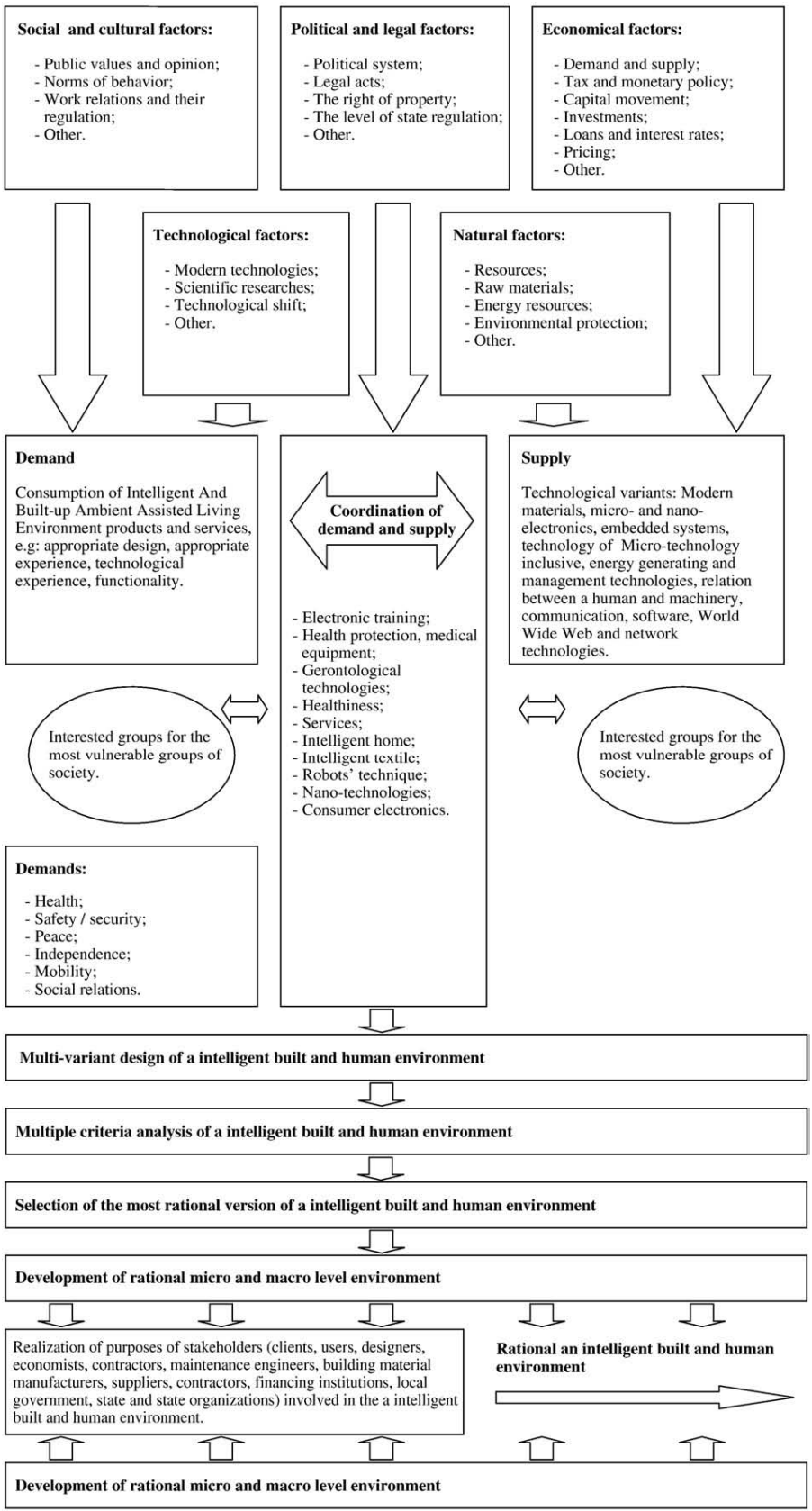

Fig. 1.3. Model for a complex analysis of intelligent built environment (Kaklauskas et al. 2010b) 
Considering the evolution of built environment definitions it can be concluded that the built environment is not constructed in empty place and relates to people in positive or even negative ways; on the other hand, built environment is directly affected by people (Tupenaite 2010). During the built environment life cycle - brief, designing, construction, maintenance, facility management, renovation, demolition and utilization - buildings are also affected by various micro, meso and macro level factors.

Tupènaitè (2010b) summarized the definitions of built environment (see Table 1.1).

Table 1.1. Definitions of built environment (Tupènaitè 2010)

\begin{tabular}{|l|l|}
\hline \multicolumn{1}{|c|}{ Author } & \multicolumn{1}{c|}{ Definition } \\
\hline Lawrence and Low (1990) & $\begin{array}{l}\text { Built environment - the result of a process of } \\
\text { social construction. }\end{array}$ \\
\hline $\begin{array}{l}\text { Crowe (1997), } \\
\text { Moffatt and Kohler (2008) }\end{array}$ & $\begin{array}{l}\text { Man made surroundings that provide the setting } \\
\text { for human activity, ranging from the large-scale } \\
\text { civic surroundings to the personal places. }\end{array}$ \\
\hline $\begin{array}{l}\text { Gaining... (2003) } \\
\text { Bartuska } \text { et al. (2007) }\end{array}$ & $\begin{array}{l}\text { Built environment relates to four interrelated } \\
\text { characteristics and seven interrelated compo- } \\
\text { nents: products, interiors, structures, landscapes, } \\
\text { cities, regions, and the Earth. }\end{array}$ \\
\hline Moffat and Kohler (2008) & $\begin{array}{l}\text { Built environment as social - ecological system. } \\
\text { The nested hierarchy grows from the building } \\
\text { footprint or parcel, through block, cluster, } \\
\text { neighbourhood, city and region. }\end{array}$ \\
\hline Glanz and Kegler (2007) & $\begin{array}{l}\text { The built environment consists of the neighbor- } \\
\text { hoods, roads, buildings, food sources, and recr- } \\
\text { eational facilities: the places in which human } \\
\text { live, work, are educated, eat and play. }\end{array}$ \\
\hline Sarkis et al. (2008) & $\begin{array}{l}\text { The built environment addresses all buildings, } \\
\text { housing, infrastructures, fixed equipment and } \\
\text { communities. It also includes the infrastructural } \\
\text { elements such as waste management, transpor- } \\
\text { tation and utility transmission systems put in } \\
\text { place to serve building space. }\end{array}$ \\
\hline Mallak et al. (2003) & $\begin{array}{l}\text { Human - made spaces where they live and work } \\
\text { in. }\end{array}$ \\
\hline $\begin{array}{l}\text { Kood (2006), } \\
\text { Kaklauskas and Zavadskas (2009) }\end{array}$ & $\begin{array}{l}\text { Environment in which buildings relate to } \\
\text { people, and vice versa. }\end{array}$ \\
\hline
\end{tabular}


Tupènaitė (2010) also proposed Conceptual Model for the Integrated Analysis of a Built and Human Environment Renovation (see Fig. 1.4).

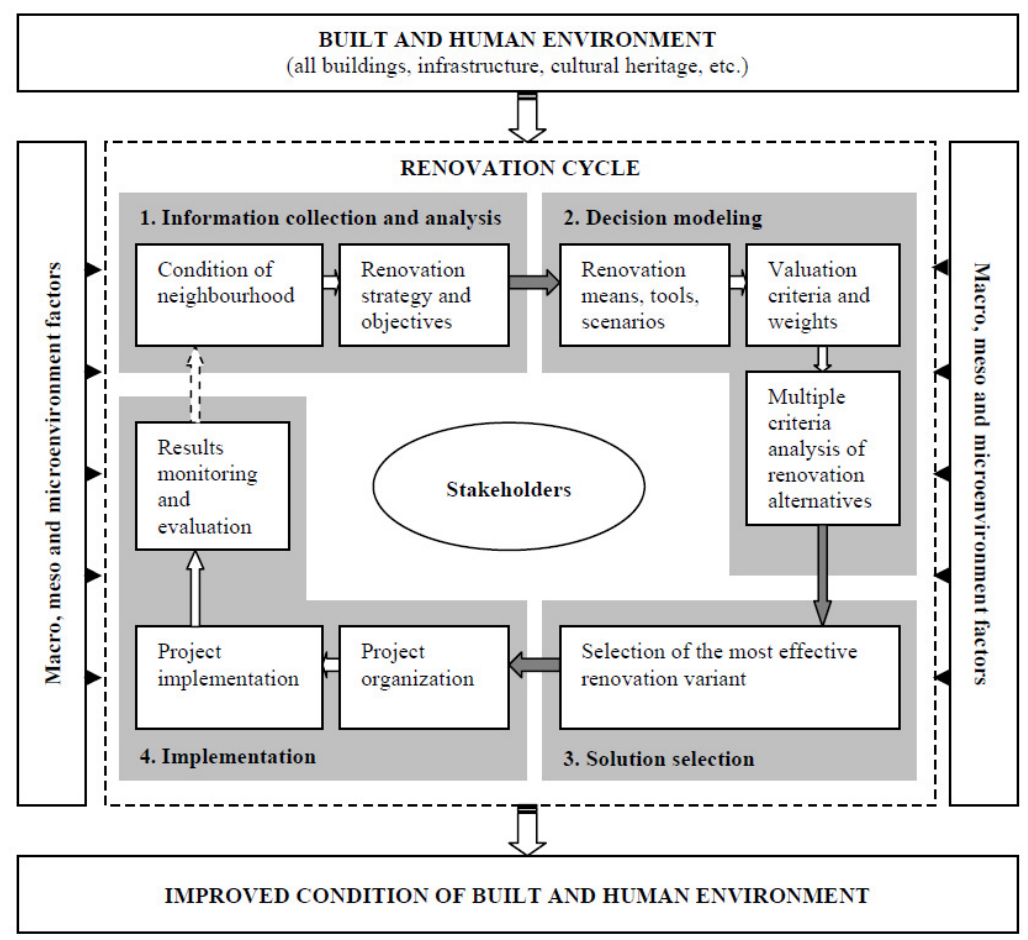

Fig. 1.4. Conceptual model for the integrated analysis of a built and human environment renovation (Tupenaite et al. 2011)

The main purpose of this model is to improve the condition of the built and human environment through efficient decision-making in renovation supported by multi objective assessment methods, considering all macro, meso and micro environment factors as well as stakeholders' needs.

The model consists of the following elements:

- macro environment factors affecting built and human environment renovation;

- meso environment factors affecting built and human environment renovation;

- micro environment factors affecting built and human environment renovation;

- stakeholders participating in the renovation process; 
- renovation cycle, consisting of four phases: information collection and analysis, decision modelling, solution selection and implementation.

\subsection{Review of Decision Support Systems}

In recent decades, the scenario of construction projects has become more complicated, dynamic and interactive. Project managers are constantly required to speed up reflective decision-makings on time. Knowledge, therefore, is noted to be one of the most important resources contributing to managerial decisionmaking and enhancing the competitive advantage of organisations carrying out such projects (Baniasa et al. 2011; Dolšak and Novak 2011; Carrillo 2004; Nonaka and Takeuchi 1995; Ruiz et al. 2012, Saa et al. 2012, Kanapeckienè et al. 2011).

The construction industry is a workplace that is dominated by heuristics. Construction companies and their personnel prefer to carry out their project management tasks on the basis of their past experiences rather than on a textbook approach or established analytical approaches (Maqsood et al. 2006). Indeed the costs of attracting, recruiting and retaining talented employees are expensive. This is further complicated by the fact that, in coming years, the construction industry is expected to lose a large portion of its skilled and knowledgeable workforce. Conversely, there is no single strategy in place to handle the construction management problems that arise. One of the most effective and powerful tools for strengthening industrial and organisational competition is through systematic identification, as per the best practice of knowledge utilisation and distribution (Bahra 2001; Kamara et al. 2002).

Knowledge has been described as information which has been used and integrated with a person's knowledge-based experience and behavioural patterns (DeTienne and Jensen 2001). Individuals have different knowledge-based capacities and experiences, and these lead to different approaches for problem-solving and decision-making. Knowledge and experience are significant when choosing a construction project manager (Ogunlana et al. 2002). Therefore project managers must be capable of knowing how to use, manage and utilise such knowledge.

A traditional practice in project management is to analyse alternatives based on economic, legal/regulatory, technical, technological, organisational and managerial approaches. Social, cultural, ethical, psychological and educational aspects of project management are less important. In order to make an integrated analysis of a project management life cycle, such a cycle must be analysed in an integrated manner using the system of criteria (Fig. 1.5). 


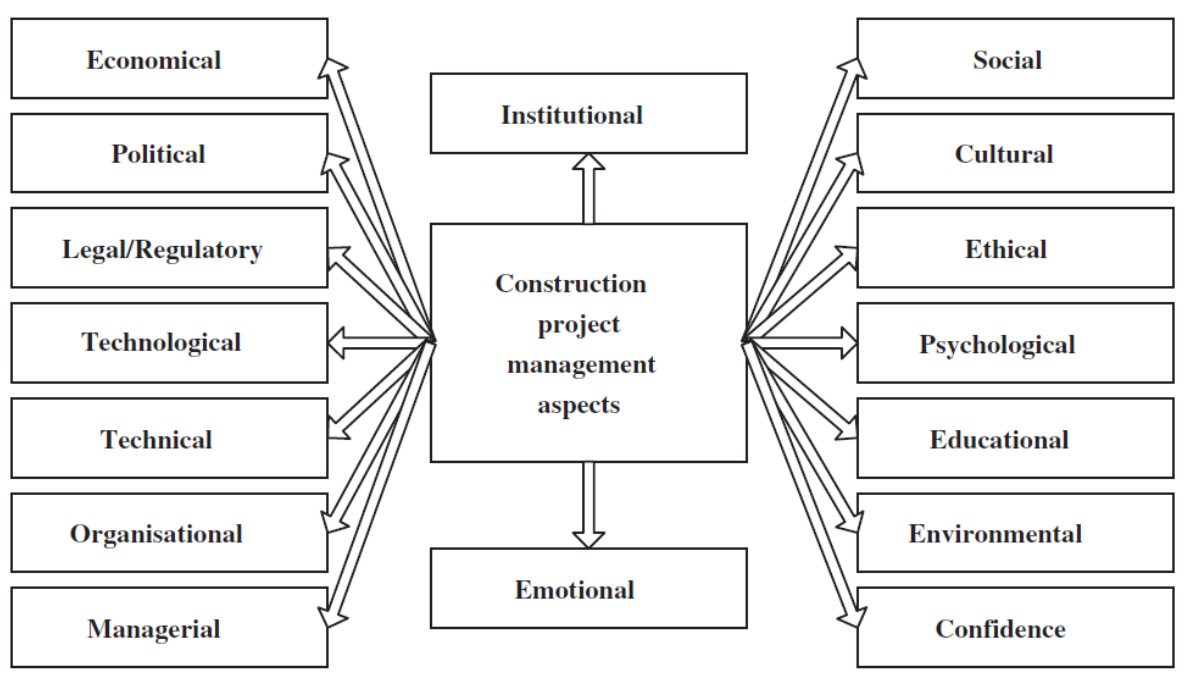

Fig. 1.5. Construction project management aspects (Kanapeckienè et al. 2010)

The analysis of works and published articles by various scientists shows the tendency to select a single, narrow knowledge management area (e.g., personnel management, management of a single project phase and such). Only a few scientists attempted an integrated analysis of knowledge management in construction. Thus there is a need to have an integrated analysis of knowledge management in the construction sector that takes into account the entire life cycle and not only emphases explicit but also tacit knowledge as well as considers all stakeholder groups and the satisfaction of their needs.

The integrated knowledge management model developed by Kanapeckienè et al. (2010) is shown in Fig. 1.6.

The effectiveness of the integrated knowledge management model which is under development depends on the combined effect of macro-level variable factors such as the level of economic, political and cultural development of a country; governmental policies (regional support programmes, control of competition, preferential loans, tax exemptions, projects commissioned by the government); legal and normative documents; the tax system; the loan granting procedure; interest rates; insurance systems; the social policy; inflation; the market; unemployment level; workforce skills; salary scales; labour laws; environment protection; customs and traditions; availability of local resources and others.

The national economic environment has a direct influence on construction. It depends on the policies by national authorities on taxes and money, capital 
movement, the investment environment, loan granting and interest rates. Demand, supply, competition, pricing and other economic factors determine the economic environment as well. The main economic indicators which define economic development are the cyclical nature of development, inflation and unemployment. These affect changes in other indicators (GDP variation, consumer income, amount of savings, prices of goods, possibilities to get loans).

The social and cultural environment includes institutions and other factors which help to shape and perceive the main social values, views and behavioural standards. A human personality matures in a certain society which determines his/her main values and beliefs.

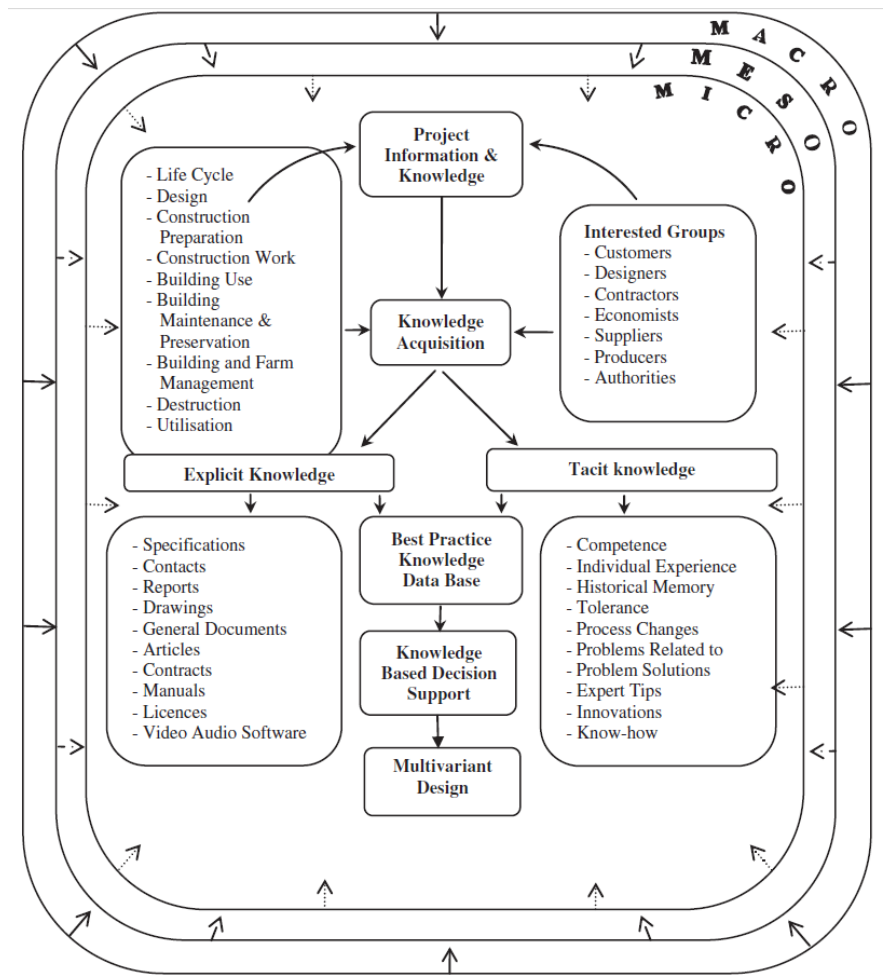

Fig. 1.6. Integrated knowledge management model for construction projects (Kanapeckienè et al. 2010)

The political and legal environment has a direct influence on the construction market. The political and legal environment consists of the political system, legal acts and ownership rights. The political and legal environment is affected by national and public agencies and organisations, as well as by other 
stakeholder groups. Business is especially sensitive to the degree of bureaucracy in the system. The complex process related to issuing building permits may be taken as an example.

The technological environment relates to new technology opening paths for new markets and new opportunities. The technological environment changes rapidly. Companies which fail to foresee a technological change in advance and keep up with it are forced out of the market. Life cycles of technologies are shrinking.

The natural environment and energy saving involve a certain natural environment in which the construction and real estate sector functions thereby affecting it and being affected by it. The natural environment supplies this sector with raw materials and resources. The Lithuanian industry of construction materials and products consumes most of the electricity and other types of energy (except for the energy industry).

Low-energy technology use in construction not only will reduce emissions of pollutants which cause the greenhouse effect but also the overall building life cycle costs. Transportation and management of debris demands additional expenses on the part of construction organisations and the state.

Meso-economic analysis is the systematic analysis of the construction and real estate sector in which both private and state organisations operate.

Basing on the discussed model, the Knowledge based Decision Support System for Construction Projects Management (KDSS-CPM) was developed (see Fig. 1.7).

\begin{tabular}{|c|c|}
\hline \multicolumn{2}{|c|}{ Decision maker } \\
\hline \multicolumn{2}{|c|}{5} \\
\hline \multicolumn{2}{|c|}{ User interface } \\
\hline 5 & 5 \\
\hline Database Managment Subsystem & Model-base Management Subsystem \\
\hline 5 & 5 \\
\hline Databases: & Model-bases: \\
\hline $\begin{array}{l}\text { - initial data tables; } \\
\text { - tablesassessing construction project solutions; } \\
\text { - tablesof a multivariant design. }\end{array}$ & $\begin{array}{l}\text { - a model for developing the alternative variants } \\
\text { of a construction project; } \\
\text { - a model for determining the initial weights of the } \\
\text { criteria (with the use of expert methods); } \\
\text { - a model for criteria weight establishment; } \\
\text { a model for the multivariant design of a } \\
\text { construction project; } \\
\text { a model for multiple criteria analysis and setting } \\
\text { priorities; } \\
\text { - a model for determining project utility degree; } \\
\text { a model for providing recommendations. }\end{array}$ \\
\hline
\end{tabular}

Fig. 1.7 Components of the knowledge based decision support system for construction projects management (Kanapeckienè et al. 2010) 
The KDSS-CPM database management system allows users to analyse the scenarios of construction processes by taking into account the system of criteria.

The analysis of database structures according to the type of problem solved reveals their various utilities. There are three basic types of database structures: hierarchical, network and relational. The KDSS-CPM system has a relational database structure when information is stored in the form of tables. These tables contain quantitative and conceptual information. Each table is given a name and is saved in the computer's external memory as a separate file. Logically linked parts of a table comprise a relational model. The following tables form the KDSS-CPM database:

- initial data tables;

- tables assessing construction project solutions;

- tables of a multi-variant design.

A module base allows the KDSS-CPM's user to select the most suitable construction alternatives by comparing the measures that promote the greatest value to all interested bodies and organisations.

Since the efficiency of a construction project variant is often determined by taking into account organisational, management, technological, economic, technical, legal, social and other factors, a model-base of a KDSS-CPM should include models enabling a decision maker to perform a comprehensive analysis of the variants available and make a proper choice. The following models of model-base are aimed to perform this function:

- a model for developing the alternative variants of a construction project;

- a model for determining the initial weights of the criteria (with the use of expert methods);

- a model for criteria weight establishment;

- a model for the multi-variant design of a construction project;

- a model for multiple criteria analysis and setting priorities;

- a model for determining project utility degree;

- a model for providing recommendations.

As example, two models (a model for multiple criteria analysis and setting priorities and a model for determining project utility degree) are described further. A model for multiple criteria analysis and setting priorities performs the multiple criteria analysis of construction project alternatives and sets project priorities based on the weighted criteria and tacit and explicit knowledge. The model for determining the project utility degree sets the utility degree for each analysed project. The Complex Proportional Assessment method (COPRAS) (Zavadskas and Kaklauskas 1999; Kaklauskas 1999) is used for these purposes. 


\subsection{Self-Assessment}

Various methodologies (Big Five Factors and Five Factor Model, intelligence quotient tests, self-assessment) are employed to predict a student's academic motivation, achievement and academic attainments. However, in the opinions of academics and practitioners alike, more than merely a student's personal attributes affects that student's advancement. Rutter and Maughan (2002) hold the opinion that the quality of a school makes a significant difference on a student's progress. A concise analysis of each of these methodologies follows.

A number of academics in the world (Komarraju et al. 2009; Noftle and Robins 2007) analyzed the role of the Big Five Factors (Openness, Conscientiousness, Extraversion, Agreeableness and Neuroticism) for predicting the academic motivation, achievement and academic attainment of students.

Noftle and Robins (2007) examined the relationships between the Big Five personality traits and academic attainments, specifically SAT scores and gradepoint averages (GPA). Openness was the strongest predictor of SAT verbal scores, and Conscientiousness was the strongest predictor of GPAs both at the high school and college levels. These relationships replicated across four independent samples and across four different personality inventories. Further analyses showed that Conscientiousness predicted college GPA, even after controlling for secondary school GPA and SAT scores and that increased academic effort and higher levels of perceived academic ability intervened both concurrently and longitudinally in the relationship between Conscientiousness and college GPA (Noftle and Robins 2007).

Komarraju et al. (2009) analysed the role of the Big Five personality traits for predicting academic motivation and achievements among college students. College undergraduates (308 students) completed the Five Factor Inventory and the Academic Motivations Scale and reported their college grade point average (GPA). A correlation analysis reveals an interesting pattern of significant relationships. Further four personality traits (Conscientiousness, Openness, Neuroticism and Agreeableness) explain 14\% of the variances in GPA, and an intrinsic motivation for accomplishment explained 5\% of the variances in GPA. Finally Conscientiousness emerges as a partial mediator of the relationship between intrinsic motivation to accomplish and GPA. These results are interpreted in the context of what educators can do to encourage and nurture student motivation and achievement (Komarraju et al. 2009).

Although IQ scores are good predictors of academic achievement in elementary and secondary school, the correspondence between IQ and academic performance is less consistent at higher levels of education, and many have questioned the ability of IQ tests to predict success later in life. The tests don't measure many of the qualities necessary for achievement in the world of work, 
such as persistence, self-confidence, motivation, and interpersonal skills, or the ability to set priorities and to allocate one's time and effort efficiently. In addition, the creativity and intuition responsible for great achievements in both science and the arts are not reflected by IQ tests. As education progresses, other factors (motivation, opportunity, organisation, background, intelligence, teaching) come into play, such that the limits are determined by the strength of the weakest link in the chain.

Self-assessment in an educational setting involves students making judgments about their own work. Students can make assessment decisions regarding their own essays, reports, projects, presentations, performances, dissertations and even exams. Self-assessment can be extremely valuable in helping students critique their own work and form judgments about its strengths and weaknesses. For obvious reasons, self-assessment is usually employed as part of a formative assessment rather than a summative process which requires certification by others. Academics and practitioners (Austin et al. 2008; Ballantine et al. 2007; Sundström 2008; Sung et al. 2009; Zimmerman and Kitsantas 2007) performed tests on self-assessment in an educational setting with groups of various ages (teenagers, college students, adults and such) in various areas (schools, universities, workplaces).

Many academics are seeking to diversify assessment tasks, broaden the range of skills assessed and provide students with more timely and informative feedback on their progress. Others wish to meet student expectations for more flexible delivery and to generate efficiencies in assessment that can ease academic staff workloads. As more students seek flexibility in their courses, it seems inevitable that there will be growing expectations for flexible assessment as well.

Numerous studies have been conducted worldwide which analyse the reliability of self-assessment. There are many controversial opinions on this issue. For example, in the opinion of Matsuno (2009), a number of researchers have reported high correlations between student- and teacher-assessments, while other studies have shown low correlations between them. Despite meta-analyses of self-assessment in higher education deeming that students will be able to selfassess accurately, the reported correlations between self and tutor evaluations within medical PBL programs are uniformly low (Papinczak et al. 2007). A great many researchers (AlFallay 2004; Braak 2004; Fitzgerald et al. 2003; Marsh et al. 1979; Mynttinen et al. 2009; Sung et al. 2005; Xiao and Lucking 2008) reached reliable results proving that the reliability of self-assessment is sufficient. Several examples of such research are further presented.

Xiao and Lucking (2008) examined the validity and reliability of student generated assessment scores. Two hundred and thirty two, predominantly undergraduate students were selected by convenience sampling during the fall seme- 
ster of 2007. The findings indicate that the validity and reliability of student generated rating scores were extremely high.

AlFallay (2004) investigates the role of some selected psychological and personality traits of learners of English as a foreign language for accuracy in their self- and peer-assessments. AlFallay (2004) obtained high reliability indices similar to those reported in the literature. The study also shows that long periods of practice and sufficient feedback have a positive effect on the accuracy of assessments. Finally the study demonstrates that students with low selfesteem are the most accurate in assessing their performance, whereas learners with instrumental motivation are the least accurate.

Although studies have examined the abilities of medical students to selfassess their performance, there are few longitudinal studies that document the stability of self-assessment accuracy over time (Fitzgerald et al. 2003).

Ballantine et al. (2007) examined the reliability of self-assessment as an indicator of students' knowledge across a variety of disciplines. As per the opinions of Ballantine et al. (2007), an agreement between self-evaluation and alternative measures of assessment has been reported in a number of studies.

Sung et al. (2005) describe the web-based self- and peer-assessments system. They show that significant consistency is found between the results of student self- and peer-assessments and the results of teacher assessments.

Marsh et al. (1979) analysed a comparison of faculty self-evaluations and the evaluations by their students. Considerable student - faculty agreement was found when 83 college courses were evaluated. Separate factor analyses indicated similar dimensions in both student and faculty evaluations. Validity coefficients were significant for all evaluation factors. Mean differences between student and faculty ratings were low, and the two groups agreed on the behaviours most descriptive of the faculty (Marsh et al. 1979).

Mynttinen et al. (2009) examined overconfidence among novice drivers by comparing their self-assessed driver competence with the assessments made by driving examiners. A Finnish $(n=2739)$ and a Dutch sample $(n=239)$ of driver's license candidates assessed their driver competence in six areas and then took the driving test. In contrast to previous studies where drivers assessed their skills in comparison to an average driver, a smaller proportion overestimated and a larger proportion made realistic self-assessments of their driver competence in the present study, where self-assessments were compared with examiner assessments. Between $40 \%$ and $50 \%$ of the candidates in both samples made realistic assessments, and 30-40\% overestimated their competence.

Ballantine et al. (2007) evaluate the reliability of self-assessment as a measure of computer competence. The scores achieved by students in self-assessed computer competence tests are compared with scores achieved in objective tests to evaluate the reliability of self-assessed computer competence. The results re- 
veal a statistically significant over-estimation of computer competence among the surveyed students.

Braak (2004) analysed the self-perceived computer competence of university students. Questionnaires were administered to two samples of first-year university students in psychology and education. The results indicated a high correlation between the two scales of computer competence.

The System developed by the author of this thesis is also based on the same presumption that, by assigning questions to students in accordance with some certain methodology (entirely unrelated with the contents of the exam) and then processing them in accordance with a certain algorithm, it is possible to determine a student's level of knowledge rather accurately. In other words, internally a student senses the rating that his/her knowledge is worth. The existing experience, intuition and analysis of the learning process give students a rather accurate indication of what mark they can expect to get during the exam.

\subsection{Intelligent Library}

Information contained in servers and user computers is constantly enlarging. As the capacity of stored information enlarges, it becomes more and more difficult to identify required materials. In other words, a problem with retrieval effectiveness is encountered.

Most advanced e-libraries select, organize, retrieve, and transmit tacit and explicit knowledge. Different reports contain explicit criticisms of the libraries' focus on their specific collections and recommendations to focus more on the user's needs. There is a need to overpass key limitations in the development of traditional libraries, i.e. libraries which have been developed for particular content and a specific group of learners. Thus, it is expected future libraries to become a practical knowledge storehouse, offering intelligent opportunities for users (Kaklauskas et al. 2007b).

Search engine rankings have been adopted in most advanced intelligent libraries (Alexandrov et al. 2003; Gutwin et al. 1999; Hsinchun et al. 1998; Kaklauskas et al. 2006c; Ruch et al. 2007; Trnkoczy et al. 2006; Wang 2003) and tutoring systems (Armani et al. 2010; Brusilovsky 2000; Day et al. 2005; Lucence 2010; Pouliquen et al. 2005). As part of the on-going Illinois Digital Library Initiative project, research proposes an intelligent personal spider (agent) approach to Internet searching, which is grounded on automatic textual analysis, general-purpose searches and genetic algorithms (Hsinchun et al. 1998). Pouliquen et al. (2005) use parsing techniques to extract information from texts, and provide a proper semantic indexation that is used by a medical-specific search engine. Day et al. (2005) use the Jakarta Lucene full-text indexer to index full- 
texts of textbooks. Jakarta Lucene is a high-performance, fully-featured text search engine library written entirely in Java. Its technology is suitable for nearly all applications that require full-text searches. ITA (Intelligent Tutoring Agent) (Pouliquen et al. 2005) index chapters, sections, and subsections of textbooks. Highlighters are used to highlight the index context. Finally, the ITA provides reading recommendations for students via a chapter similarity function. However, intelligent libraries (Alexandrov et al. 2003; Gutwin et al. 1999; Hsinchun et al. 1998; Kaklauskas et al. 2006c; Ruch et al. 2007; Trnkoczy et al. 2006; Wang 2003) and intelligent tutoring systems (Armani et al. 2010; Brusilovsky and Peylo 2000; Day et al. 2005; Lucence 2010; Pouliquen et al. 2005) with search engine rankings cannot select chapters (sections, paragraphs) of specific texts, which are the most relevant to a student, cannot integrate the chapters (sections, paragraphs) of specific texts into learner specific alternatives of teaching material and cannot select the most rational alternative, i.e. cannot develop alternatives of training materials, perform multiple criteria analysis and automatically select the most effective variant. However, the proposed Intelligent Library Subsystem and Tutoring System can perform the afore-mentioned functions. To the best of author's knowledge, the above function has not been implemented before. The proposed approach helps students to obtain suitably tailored material for any e-learning course.

The known retrieval methods and systems are not enough flexible in search (Kaklauskas et al. 2007b). Selected out electronic information is not enough informative and concentrated, because do not perform breaking down the text material from the library of documents into composite parts (chapters/sections/paragraphs) and not perform their analyses according to the initial query for selecting number of most appropriate for the user composite parts which further are combined into different optional combinations by adding each to other from different documents for creating set of many different alternative text variants and after multiple criteria analyses selecting out the best said alternative text variants.

\subsection{Conclusions for Chapter 1}

1. Definition of intelligent tutoring system and built environment was specified.

2. History of Intelligent Tutoring Systems was reviewed and main ITS components were specified.

3. Best up to date practice systems and models were analysed to improve the model proposed by author. 
4. Self-assessment in an educational setting involves students making judgments about their own work. Students can make assessment decisions regarding their own essays, reports, projects, presentations, performances, dissertations and even exams. Self-assessment can be extremely valuable in helping students critically review their own work and form judgments about its strengths and weaknesses.

5. No real life system for "Built environment" studies process was found. Models used for solving one specified problem can be found in many authors' publications, but there are no real life systems for specific field, that can be used for the whole learning process, not only for single calculations.

6. Existing ITSs do not perform:

- Personalized search (when billions learning alternatives are created and the best is selected);

- Adaptive and personalized learning and teaching (according to the student's curiosity, stress and preferred learning difficulty levels);

- Billions of alternatives analysis while performing homeworks, course projects and final works. 


\section{2}

\section{Multi Objective Assessment Methods for Intelligent Tutoring System}

In this chapter main multi objective assessment methods are reviewed and compared. Best suitable methods for Intelligent Tutoring System for Built Environment are more deeply described.

On the thematic of this chapter 4 publications (Kanapeckienè et al. 2010; Tupènaitè et al. 2010; Urbanavičienè et al. 2009; Kaklauskas et al. 2007b) were published.

\subsection{Review of Multi Objective Assessment Methods}

There are many multi objective assessment methods that can be used for development of the multi objective assessment systems (MOAS). For example, COPRAS, EVAMIX, TOPSIS, VIKOR, AHP methods can be found implemented in different decision support systems (Chatterjee et al. 2011; Tupenaitè 2010b; Simanavičienè 2010; Kaklauskas et al. 2007a; Zavadskas et al. 2008a; Dasa et al. 2011; Maitya et al. 2012; Chinese et al. 2011; Podvezko 2011; Užšilaityte and Martinaitis 2010; Bindu Madhuri et al. 2010; Datta et al. 2009; Ginevičius and Podvezko 2008; Karbassi et al. 2008). Zavadskas and Turskis (2011) successfully grouped multiple criteria decision making methods in one scheme (see Fig. 2.1). 


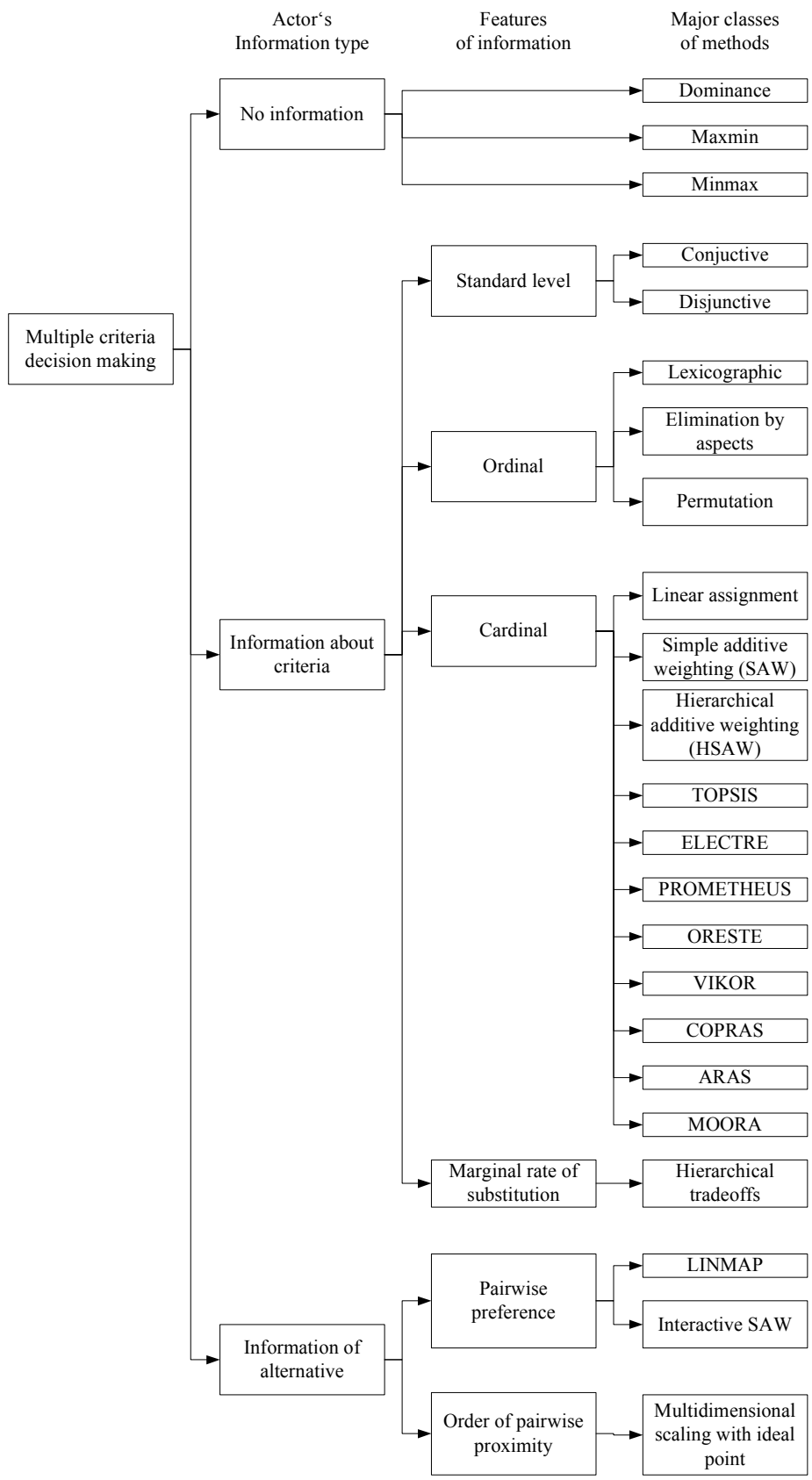

Fig. 2.1. Grouping of multiple criteria decision making methods (Zavadskas and Turskis 2011) 
The problem of selecting correct method for author's calculations can be solved by comparing them and selecting the optimal one. Chatterjee et al. (2011) have compared these methods (see Table 2.1).

Table 2.1. Performance of some multi objective assessment methods (Chatterjee et al. 2011)

\begin{tabular}{|l|l|l|l|l|l|}
\hline Method & COPRAS & EVAMIX & TOPSIS & VIKOR & AHP \\
\hline $\begin{array}{l}\text { Calculation } \\
\text { time }\end{array}$ & Less & Moderate & High & Less & $\begin{array}{l}\text { Very } \\
\text { high }\end{array}$ \\
\hline Simplicity & Very simple & $\begin{array}{l}\text { Moderately } \\
\text { critical }\end{array}$ & $\begin{array}{l}\text { Moderately } \\
\text { critical }\end{array}$ & Simple & $\begin{array}{l}\text { Very } \\
\text { critical }\end{array}$ \\
\hline Transparency & Very good & Reasonable & Good & Reasonable & Low \\
\hline $\begin{array}{l}\text { Possibility of } \\
\text { graphical } \\
\text { interpretation }\end{array}$ & Very high & Low & Low & Low & Good \\
\hline $\begin{array}{l}\text { Information } \\
\text { type }\end{array}$ & Quantitative & Mixed & Quantitative & Quantitative & Mixed \\
\hline
\end{tabular}

The comparison of presented methods allows coming to conclusion that COPRAS method has noticeable advantages among the other methods.

Calculation time is very short, the same as VIKOR. COPRAS method can be easily implemented to any program source code. Understanding and result checking is very common. Calculation results can be easily visualized and interpreted. For this purpose COPRAS method was selected for development of the Intelligent Tutoring System for Built Environment.

This method can be successfully applied in Intelligent Tutoring System for Built Environment for:

- $\quad$ selection of personalized study materials for student;

- selection of tasks or tests;

- information search;

- built environment projects evaluation.

The main stages of the COPRAS method's implementation into Intelligent Tutoring System are further discussed in detail. 


\subsection{A Method of Multiple Criteria Complex Proportional Evaluation Adopted for the Intelligent Tutoring System for Built Environment}

A Method of Multiple Criteria Complex Proportional Evaluation (COPRAS) was developed by Zavadskas and Kaklauskas in 1996. It assumes direct and proportional dependence of significance and priority by versions investigated on a system of criteria adequately describing the alternatives and on the values and weights of the criteria. A system of criteria is determined, and experts calculate the values and initial weights of criteria. All this information can be adjusted by interested parties (customers, users, etc.) considering their goal pursuits and existing capabilities. Hence the results of the assessment of alternatives fully reflect the initial data that was jointly submitted by experts and interested parties.

This method can be successfully applied in Intelligent Tutoring System for Built Environment for selection of personalized study materials for student. In order to achieve this, system should generate criteria system and parameters of material alternatives as well as individual parameters chosen by student. This solution is suitable for both selection of materials and provision of recommendations.

Method is also suitable for selection of tasks or tests. ITSBE is able to make recommendations by preparing individual system of criteria and performing of calculations. In this way system reacts to changes of student's individual settings and learning process.

It is hard to imagine modern learning without search of information resources whose number is constantly increasing. Frequently there are situations when selection from similar content information resources' alternatives is needed. Based on the method discussed above, ITSBE analyses possible information search results and helps to choose the best alternative. In order to make a search it is it is possible to formulate system of criteria from standard search criteria, student study field criteria and personal settings.

In cases of built environment projects' evaluation, method helps to form individual systems of criteria in order to evaluate project alternatives. Initially created system of criteria with particular modifications could be used for evaluation of new different projects as a template.

In order to integrate such terms as tests, teaching material, search result and built environment project alternatives, term "generalized alternative" further will be used.

The determination of the significance and priority of generalized alternatives is carried out in 5 stages. 
Stage 1 . The weighted, normalised decision-making matrix is formed. The purpose of this stage is to receive dimensionless weighted values from the comparative indexes. When the dimensionless values of the indexes are known, all criteria, originally having different dimensions, can be compared. The following formula is used for this purpose:

$$
d_{i j}=\frac{x_{i j} \cdot q_{i}}{\sum_{j=1}^{n} x_{i j}} ; i=\overline{1, m} ; j=\overline{1, n},
$$

where: $d_{i j}$ - the dimensionless weighted index value; $x_{i j}$ - the value of the $i^{\text {th }}$ criterion in the $j^{\text {th }}$ alternative of a solution; $m$ - the number of criteria; $n-$ the number of the generalized alternatives compared; $q_{i}$ - weight of the $i^{\text {th }}$ criterion.

Table 2.2. Sorted decision-making matrix for a multiple criteria analysis

\begin{tabular}{|c|c|c|c|c|c|c|c|c|c|}
\hline \multicolumn{10}{|c|}{ Quantitative project information } \\
\hline \multirow{2}{*}{$\begin{array}{l}\text { Analysed crite- } \\
\text { ria }\end{array}$} & \multirow{2}{*}{$*$} & \multirow{2}{*}{ Weights } & \multirow{2}{*}{ Units } & \multicolumn{6}{|c|}{ Analysed projects } \\
\hline & & & & $a_{1}$ & $a_{2}$ & $\ldots$ & $a_{j}$ & $\ldots$ & $a_{n}$ \\
\hline \multirow{6}{*}{$\begin{array}{l}\text { Quantitative } \\
\text { criteria }\end{array}$} & $w_{1}$ & $q_{1}$ & $m_{1}$ & $x_{11}$ & $x_{12}$ & $\cdots$ & $x_{1 j}$ & $\cdots$ & $x_{1 n}$ \\
\hline & $w_{2}$ & $q_{2}$ & $m_{2}$ & $x_{21}$ & $x_{22}$ & $\ldots$ & $x_{2 j}$ & $\ldots$ & $x_{2 n}$ \\
\hline & $\ldots$ & $\ldots$ & $\ldots$ & $\ldots$ & $\ldots$ & $\ldots$ & $\ldots$ & $\ldots$ & $\ldots$ \\
\hline & $w_{i}$ & $q_{i}$ & $m_{i}$ & $x_{i 1}$ & $x_{i 2}$ & $\cdots$ & $x_{i j}$ & $\cdots$ & $x_{i n}$ \\
\hline & $\cdots$ & $\ldots$ & $\ldots$ & $\ldots$ & $\cdots$ & $\cdots$ & $\cdots$ & $\cdots$ & $\ldots$ \\
\hline & $w_{t}$ & $q_{t}$ & $m_{t}$ & $x_{t 1}$ & $x_{t 2}$ & $\ldots$ & $x_{t j}$ & $\ldots$ & $x_{t n}$ \\
\hline \multirow{6}{*}{$\begin{array}{l}\text { Qualitative } \\
\text { criteria }\end{array}$} & $w_{t+1}$ & $q_{t+1}$ & $m_{t+1}$ & $x_{t+11}$ & $x_{t+12}$ & $\ldots$ & $x_{t+1 j}$ & $\ldots$ & $x_{t+1 n}$ \\
\hline & $w_{t+2}$ & $q_{t+2}$ & $m_{t+2}$ & $x_{t+21}$ & $x_{t+22}$ & $\ldots$ & $x_{t+2 j}$ & $\ldots$ & $x_{t+2 n}$ \\
\hline & $\ldots$ & $\ldots$ & $\ldots$ & $\ldots$ & $\ldots$ & $\ldots$ & $\ldots$ & $\ldots$ & $\ldots$ \\
\hline & $w_{i}$ & $q_{i}$ & $m_{i}$ & $x_{i 1}$ & $x_{i 2}$ & $\cdots$ & $x_{i j}$ & $\ldots$ & $x_{i n}$ \\
\hline & $\ldots$ & $\ldots$ & $\ldots$ & $\ldots$ & $\ldots$ & $\ldots$ & $\ldots$ & $\ldots$ & $\ldots$ \\
\hline & $w_{m}$ & $q_{m}$ & $m_{m}$ & $x_{m 1}$ & $x_{m 2}$ & $\ldots$ & $x_{m j}$ & $\ldots$ & $x_{m n}$ \\
\hline
\end{tabular}

* - Sign $w_{i}(+/-)$ shows, respectively, the better/poorer value of the criterion of requirements

The sum of the dimensionless weighted index value $d_{i j}$ for each criterion $x_{i}$ is always equal to the weight $q_{i}$ of this criterion:

$$
q_{i}=\sum_{j=1}^{n} d_{i j} ; i=\overline{1, m} ; j=\overline{1, n} .
$$


In other words, the value of weight $q_{i}$ of the investigated criterion is proportionally distributed among all alternative versions $a_{j}$ according to their values $x_{i j}$.

An example of the decision-making matrix for a multiple criteria analysis of built environment project is presented in Table 2.2.

Stage 2. The sums of weighted, normalised indexes describing the $j^{\text {th }}$ version are calculated. The versions are described by minimising indexes $S_{-j}$ and maximising indexes $S_{+j}$. The lower value of minimised indexes is better and the greater value of maximised indexes is better. The sums are calculated according to the formula:

$$
S_{+j}=\sum_{i=1}^{m} d_{+i j} ; S_{-j}=\sum_{i=1}^{m} d_{-i j} ; i=\overline{1, m} ; j=\overline{1, n} .
$$

In this case, the values $S_{+j}$ (the greater this value, the more satisfied are the interested parties) and $S_{-j}$ (the lower this value, the better the goal attainment by the interested parties) express the degree of goals attained by the interested parties in each alternative project. In any case, the sums of "pluses" $S_{+j}$ and "minuses" $S_{-j}$ of all generalized alternatives are always, respectively, equal to all sums of the weights of maximised and minimised criteria:

$$
\begin{gathered}
S_{+}=\sum_{j=1}^{n} S_{+j}=\sum_{i=1}^{m} \sum_{j=1}^{n} d_{+i j} ; \\
S_{-}=\sum_{j=1}^{n} S_{-j}=\sum_{i=1}^{m} \sum_{j=1}^{n} d_{-i j} ; i=\overline{1, m} ; j=\overline{1, n} .
\end{gathered}
$$

Stage 3. The significance (efficiency) of the compared versions is determined by describing the characteristics of positive generalized alternatives ("pluses") and negative generalized alternatives ("minuses"). The relative significance $Q_{j}$ of each alternative $a_{j}$ is found according to the formula:

$$
Q_{j}=S_{+j}+\frac{S_{-\min } \cdot \sum_{j=1}^{n} S_{-j}}{S_{-j} \cdot \sum_{j=1}^{n} \frac{S_{-\min }}{S_{-j}}} ; j=\overline{1, n} .
$$

Stage 4. The priorities of the generalized alternatives are determined. The greater is the $Q_{j}$ the higher is the efficiency (priority) of the alternative (i.e., built environment project alternative).

The analysis of the method presented makes it possible to state that it may be easily applied for evaluating projects and selecting the most efficient of them while being fully aware of the physical meaning of the process. Moreover, it allows formulating a reduced criterion $Q_{j}$ which is directly proportional to the relative effect of the compared criteria values $x_{i j}$ and weights $q_{i}$ on the end result. 
Significance $Q_{j}$ of project $a_{j}$ indicates the degree of satisfaction of demands and goals pursued by the interested parties - the greater is the $Q_{j}$ the higher is the efficiency of the project (see Table 2.3).

Table 2.3. Results of the multiple criteria analysis

\begin{tabular}{|c|c|c|c|c|c|c|c|c|c|}
\hline \multicolumn{10}{|c|}{ Quantitative project information } \\
\hline \multirow{2}{*}{$\begin{array}{l}\text { Analysed } \\
\text { criteria }\end{array}$} & \multirow{2}{*}{$*$} & \multirow{2}{*}{ Weights } & \multirow{2}{*}{ Units } & \multicolumn{6}{|c|}{ Analysed generalized alternative } \\
\hline & & & & $a_{1}$ & $a_{2}$ & $\ldots$ & $a j$ & $\ldots$ & an \\
\hline$X_{1}$ & $w_{1}$ & $q_{1}$ & $m_{1}$ & $d_{11}$ & $d_{12}$ & $\ldots$ & $d_{1 j}$ & $\ldots$ & $d_{1 n}$ \\
\hline$X_{2}$ & $w_{2}$ & $q_{2}$ & $m_{2}$ & $d_{21}$ & $d_{22}$ & $\cdots$ & $d_{2 j}$ & $\ldots$ & $d_{2 n}$ \\
\hline$X_{3}$ & $w_{3}$ & $q_{3}$ & $m_{3}$ & $d_{31}$ & $d_{32}$ & $\ldots$ & $d_{3 j}$ & $\ldots$ & $d_{3 n}$ \\
\hline$\ldots$ & $\ldots$ & $\ldots$ & $\ldots$ & $\ldots$ & $\ldots$ & $\ldots$ & $\ldots$ & $\ldots$ & $\ldots$ \\
\hline$X_{i}$ & $w_{i}$ & $q_{i}$ & $m_{i}$ & $d_{i 1}$ & $d_{i 2}$ & $\ldots$ & $d_{i j}$ & $\ldots$ & $d_{i n}$ \\
\hline$\cdots$ & $\ldots$ & $\ldots$ & $\ldots$ & $\ldots$ & $\ldots$ & $\ldots$ & $\ldots$ & $\ldots$ & $\ldots$ \\
\hline$X_{m}$ & $w_{m}$ & $q_{m}$ & $m_{m}$ & $d_{m 1}$ & $d_{m 2}$ & $\ldots$ & $d_{m j}$ & .. & $d_{m n}$ \\
\hline \multicolumn{4}{|c|}{$\begin{array}{l}\text { Sum of maximising normalised rated indica- } \\
\text { tors (generalized alternative advantages) }\end{array}$} & $S_{+1}$ & $S_{+2}$ & $\ldots$ & $S_{+j}$ & $\ldots$ & $S_{+n}$ \\
\hline \multicolumn{4}{|c|}{$\begin{array}{l}\text { Sum of minimising normalised rated indica- } \\
\text { tors (generalized alternative disadvantages) }\end{array}$} & $S_{-1}$ & $\overline{S_{-2}}$ & $\ldots$ & $S_{-j}$ & $\ldots$ & $S_{-n}$ \\
\hline \multicolumn{4}{|c|}{ Significance of the generalized alternative } & $Q_{1}$ & $Q_{2}$ & $\ldots$ & $Q_{j}$ & $\ldots$ & $Q_{n}$ \\
\hline \multicolumn{4}{|c|}{ Priority of the generalized alternative } & $P_{1}$ & $P_{2}$ & $\ldots$ & $P_{j}$ & $\ldots$ & $P_{n}$ \\
\hline \multicolumn{4}{|c|}{ Generalized alternative utility degree } & $N_{1}$ & $N_{2}$ & $\ldots$ & $N_{j}$ & $\ldots$ & $N_{n}$ \\
\hline
\end{tabular}

* - Sign $w_{i}(+/-)$ shows, respectively, the better/poorer value of the criterion of requirements

Stage 5. The degree of project utility directly associates with its relevant quantitative and conceptual information. If one project is described as the best comfort, aesthetics and price indexes, while another is shown with better maintenance and facilities management characteristics, both will have obtained the same significance values as a result of the multi objective assessment; this means their utility degree is also the same. With an increase (decrease) in the significance of the project analysed, the project's degree of utility also increases (decreases). The degree of project utility is determined by comparing the project analysed with the most efficient project. In this case, all the utility degree values related to the project analysed will range from $0 \%$ to $100 \%$. This will facilitate a visual assessment of the project's efficiency.

The formula used for calculating alternative $a_{j}$ utility degree $N_{j}$ is the following:

$$
N_{j}=\frac{Q_{j}}{Q_{\max }} \cdot 100 \% \text {. }
$$

where: $N_{j}$ - the degree of $j^{\text {th }}$ project utility; $Q_{j}-$ the relative significance of $j^{\text {th }}$ project; $Q_{\max }$ - the most efficient relative significance from the existing projects. 
The above mentioned steps can be summarized in a scheme which describes all the processes (Fig. 2.2).

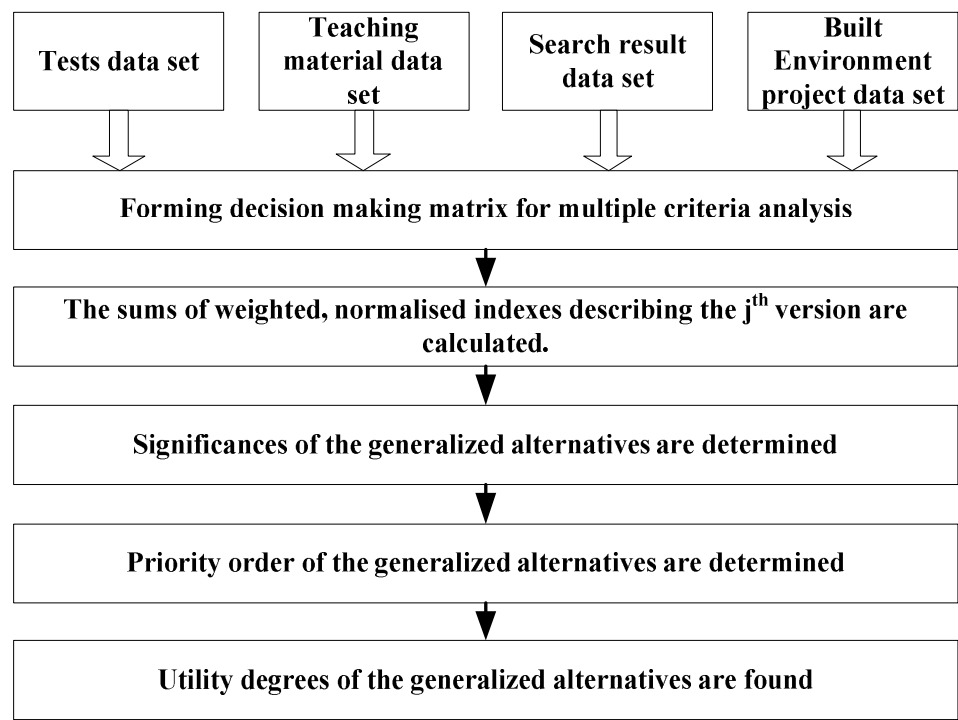

Fig. 2.2. Main stages of determination of the significance and priority of generalized alternatives (Created by author)

The presented scheme shows that on the basis of initial data it is possible to select the best test, teaching material, search result or the best built environment project alternative.

\subsection{The Method of Multiple Criteria Multivariant Design Adopted for the Intelligent Tutoring System for Built Environment}

A lot of data has to be processed and evaluated in carrying out, for example, multivariant design of a built environment project. The number of feasible project alternatives can be as large as 100,000. Each of the alternatives may be described from various perspectives, e.g., by conceptual and quantitative information. The problem arises how to perform computer-aided design of the alternative variants based on this enormous amount of information. To solve this problem a Method of Multiple Criteria Multivariant Design was adopted for Intelligent Tutoring System for Built Environment. 
The developed method can be applied not only for evaluation of built environment projects but also for various tasks solutions in the Intelligent Tutoring System for Built Environment.

In order to create individual study plan for student multivariant design can be used. If there is enough information collected in the system, it is able, on the basis of this method, to generate possible variants and present the best alternative of study plan.

The method is also very useful for making tests and their evaluation. Because of easily formulated system of criteria it allows to take into account the general requirements as well as personal student criteria in making and selection of tests.

In the cases of information search usually more than one keyword is used. For this purpose it is important to use a method which allows both to evaluate search results and to weight the importance of keywords. The discussed method in Intelligent Tutoring System for Built Environment can solve this problem.

As previously, to integrate such terms as tests, teaching material, search result and built environment project alternatives, term "generalized alternative" further will be used.

On the basis on the discussed method multiple criteria multivariant design is carried out in 5 stages (Fig. 2.3). Initial step is data set.

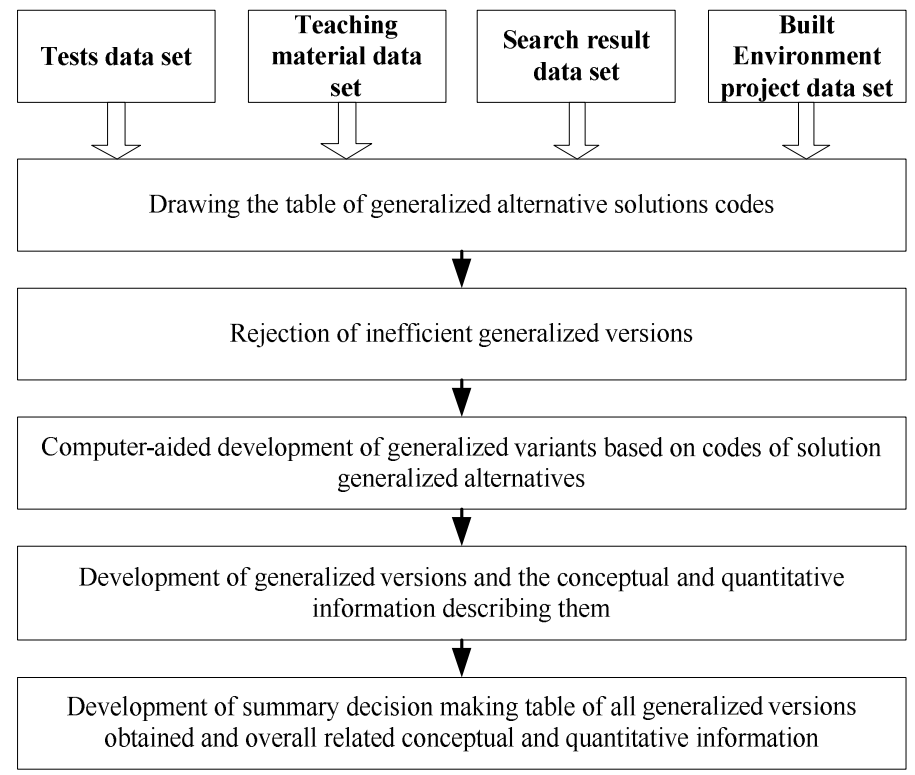

Fig. 2.3. Main stages of multiple criteria multivariant design (Created by author) 
In order to reduce the amount of information being used in computer-aided multivariant design the codes of the generalized alternative solutions are used. In this case, any $i^{\text {th }}$ solution of $j^{\text {th }}$ alternative is given $a_{i j}$ code providing thorough quantitative (system of criteria, units of measure, significances, values, as well as a minimizing or maximizing criterion) and conceptual (text, drawings, graphics, video tapes) information about the generalized alternative being considered (see Table 2.4). Thus, the use of codes of the generalized alternative solutions in computer-aided multivariant design reduces the volume of information to be processed providing better insight into a physical meaning of computations.

Codes, with conceptual and quantitative information provided, are used for describing all available generalized alternative solutions.

The total number of these codes makes the table of codes of generalized alternatives allowing getting the alternative versions in a more simple way (see Table 2.4). As can be seen from Table 2.4, it contains $c$ solutions of a built environment project (plots, buildings, parking, etc.) of the $n_{i}$ alternative versions codes. Any $i^{\text {th }}$ line of the code table represents the codes of $A_{i}$ solution $a_{i j}$ alternatives. If the information relating to the solutions in the code table of generalized alternatives is represented by codes, then the code contains quantitative and conceptual information. In this case, $n_{i}$ alternatives of any $i$ solution are being considered in developing the alternative versions of a built environment project.

Table 2.4. Codes of generalized alternative solutions with conceptual and quantitative information (as example for built environment project)

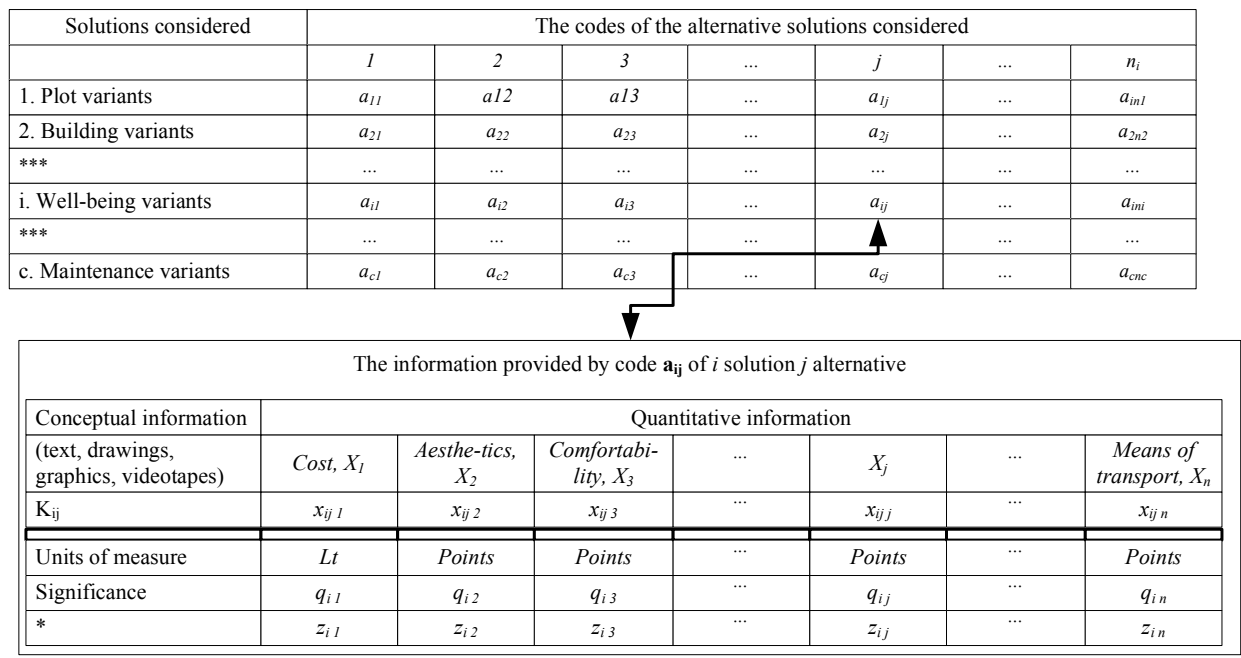

* - Signs $z_{i j}(+(-))$ mean, that corresponding higher (lower) value of the criterion 
Thus, the maximum number of the projects obtained may be computed as follows:

$$
k=\prod_{i=1}^{c} n_{i},
$$

where: $c$ is the number of solutions considered in determining a built environment project(as example); $n_{i}$ is the number of $i$ solution alternatives to be used in developing a built environment project (as example).

For example, if in determining possible built environment project alternative versions 10 alternatives are considered for any of 10 solutions, then, according to equation (2.7) maximum ten billion such variants will be obtained. It is evident that in this and similar cases it is hardly possible and reasonable to analyse all the versions from various perspectives. Therefore, it is advisable to reduce their number as follows. If a project of $c$ solutions having $n_{i}$ alternatives allows $k$ combinations (equation 2.7) then, by using multiple criteria analysis methods, $p$ most efficient versions should be chosen from every solution for further consideration (see Table 2.5). In this way, inefficient variants are being removed. The best solutions alternatives obtained are then grouped according to priority considerations. In Table $2.5 a_{i 1}$ is a code of the best variant of $i$ solution, while $a_{i p}$ is a code of its worst version.

Then, generalized variants are being developed based on the efficient $p$ alternatives of $c$ solutions chosen. At the beginning, this process should involve the codes of the generalized alternative solutions. The first generalized variant is obtained by analysing the best solution generalized variants according to the priority order (see Tables 2.4 and 2.5). The last generalized variant is based on solution versions from the bottom of priority table, while intermediate variants are obtained with account of the versions found in the middle of this table.

Table 2.5. Most efficient solution alternatives set according their priorities (as example for built environment project)

\begin{tabular}{|l|l|l|l|l|l|l|l|}
\hline Solutions considered & \multicolumn{6}{|l|}{ Priority of the best generalized alternative } \\
& solutions \\
\hline & 1 & 2 & 3 & $\ldots$ & $j$ & $\ldots$ & $p$ \\
\hline 1. Plot variants & $a_{11}$ & $a_{12}$ & $a_{13}$ & $\ldots$ & $a_{1 j}$ & $\ldots$ & $a_{1 p}$ \\
\hline 2. Building variants & $a_{21}$ & $a_{22}$ & $a_{23}$ & $\ldots$ & $a_{2 j}$ & $\ldots$ & $a_{2 p}$ \\
\hline$\ldots$ & $\ldots$ & $\ldots$ & $\ldots$ & $\ldots$ & $\ldots$ & $\ldots$ & $\ldots$ \\
\hline$i$. Well-being variants & $a_{i 1}$ & $a_{i 2}$ & $a_{i 3}$ & $\ldots$ & $a_{i j}$ & $\ldots$ & $a_{i p}$ \\
\hline$\ldots$ & $\ldots$ & $\ldots$ & $\ldots$ & $\ldots$ & $\ldots$ & $\ldots$ & $\ldots$ \\
\hline$c$. Maintenance variants & $a_{c 1}$ & $a_{c 2}$ & $a_{c 3}$ & $\ldots$ & $a_{c j}$ & $\ldots$ & $a_{c p}$ \\
\hline
\end{tabular}


For example, the first built environment project version is based on $a_{11}$ plot, $a_{21}$ building, $a_{i 1}$ well-being, $a_{c 1}$ maintenance, etc. variants. The last building life cycle version takes into account $a_{1 p}$ plot, $a_{2 p}$ building, $a_{i p}$ well-being, $a_{c p}$ maintenance, etc. variants. In this case, combinations are obtained by using $p$ alternatives from any $c$ solutions. Therefore, the maximum number of the projects obtained may be determined from the following expression:

$$
K=\prod_{i=1}^{c} p
$$

where $c$ is the number of solutions used in determining a building life cycle; $p$ is the number of the best generalized variants of every solution used in developing a built environment project (as an example).

In Table 2.6 the development of generalized alternatives, based on codes of solution alternatives is presented.

Table 2.6. Computer-aided development of generalized variants based on codes of solution alternatives (as example for built environment project)

\begin{tabular}{|l|l|l|l|l|l|l|l|l|l|l|l|l|}
\hline Solutions considered & \multicolumn{9}{|c|}{ Development of generalized variants based on codes of solution } \\
& alternatives \\
\hline & 1 & 2 & 3 & $\ldots$ & $p$ & $p+1$ & $p+2$ & $p+3$ & $\ldots$ & $2 p$ & $\ldots$ & $K$ \\
\hline 1. Plot variants & $a_{11}$ & $a_{11}$ & $a_{11}$ & $\ldots$ & $a_{11}$ & $a_{11}$ & $a_{11}$ & $a_{11}$ & $\ldots$ & $a_{11}$ & $\ldots$ & $a_{1 p}$ \\
\hline 2. Building variants & $a_{21}$ & $a_{21}$ & $a_{21}$ & $\ldots$ & $a_{21}$ & $a_{21}$ & $a_{21}$ & $a_{21}$ & $\ldots$ & $a_{21}$ & $\ldots$ & $a_{2 p}$ \\
\hline$\ldots$ & $\ldots$ & $\ldots$ & $\ldots$ & $\ldots$ & $\ldots$ & $\ldots$ & $\ldots$ & $\ldots$ & $\ldots$ & $\ldots$ & $\ldots$ & $\ldots$ \\
\hline$i$. Well-being variants & $a_{i 1}$ & $a_{i 1}$ & $a_{i 1}$ & $\ldots$ & $a_{i 1}$ & $a_{i 1}$ & $a_{i 1}$ & $a_{i 1}$ & $\ldots$ & $a_{i 1}$ & $\ldots$ & $a_{i p}$ \\
\hline$\ldots$ & $\ldots$ & $\ldots$ & $\ldots$ & $\ldots$ & $\ldots$ & $\ldots$ & $\ldots$ & $\ldots$ & $\ldots$ & $\ldots$ & $\ldots$ & $\ldots$ \\
\hline$c-1$ & $a_{c-11}$ & $a_{c-11}$ & $a_{c-11}$ & $\ldots$ & $a_{c-11}$ & $a_{c-12}$ & $a_{c-12}$ & $a_{c-12}$ & $\ldots$ & $a_{c-12}$ & $\ldots$ & $a_{c-1} p$ \\
\hline$c$. Maintenance variants & $a_{c 1}$ & $a_{c 2}$ & $a_{c 3}$ & $\ldots$ & $a_{c p}$ & $a_{c 1}$ & $a_{c 2}$ & $a_{c 3}$ & $\ldots$ & $a_{c p}$ & $\ldots$ & $a_{c p}$ \\
\hline
\end{tabular}

Table 2.7 presents conceptual and quantitative information about the generalized variants instead of the codes. When a particular built environment project is being considered the values relating to various solutions but based on the same criterion are recalculated into a single reduced value.

The reduction of the same criterion (e.g. cost, comfortability) values of various solutions (plot, building, well-being, maintenance) to a single one it is necessary to appraise significances of these solutions. For example, noise level within and outside the building is not of the same significance to its inhabitants. 
Table 2.7. Development of generalized variants and related conceptual and quantitative information (as example for built environment project)

\begin{tabular}{|c|c|c|c|c|c|c|c|c|}
\hline \multirow{3}{*}{$\begin{array}{c}\text { Solutions used in } \\
\text { developing generalized variants }\end{array}$} & \multicolumn{8}{|c|}{ Information related to generalized versions } \\
\hline & \multirow{2}{*}{$\begin{array}{c}\text { Concep- } \\
\text { tual }\end{array}$} & \multicolumn{7}{|c|}{ Quantitative } \\
\hline & & $\begin{array}{l}\text { Cost, } \boldsymbol{X}_{1} \\
(\mathrm{Lt})\end{array}$ & $\begin{array}{l}\text { Aesthetics, } \\
\boldsymbol{X}_{\mathbf{2}} \text { (Points) }\end{array}$ & $\begin{array}{l}\text { Comforta- } \\
\text { bility, } \quad \boldsymbol{X}_{\mathbf{3}} \\
\text { (Points) }\end{array}$ & $\ldots$ & $\boldsymbol{X}_{j}$ & $\cdots$ & \begin{tabular}{|l} 
Means of \\
transport, \\
$\boldsymbol{X}_{\boldsymbol{n}}$ \\
(Points)
\end{tabular} \\
\hline & \multicolumn{8}{|c|}{ Information related to life cycle of 1-st building } \\
\hline 1. Plot, $a_{11}$ & $K_{11}$ & $x_{111}$ & $x_{112}$ & $x_{113}$ & $\ldots$ & $x_{11 j}$ & $\ldots$ & $x_{11 n}$ \\
\hline 2. Building, $\boldsymbol{a}_{21}$ & $K_{21}$ & $x_{211}$ & $x_{212}$ & $x_{213}$ & $\ldots$ & $x_{21 j}$ & $\ldots$ & $x_{21 n}$ \\
\hline$\ldots$ & & $\ldots$ & $\ldots$ & $\ldots$ & $\ldots$ & $\ldots$ & $\ldots$ & $\ldots$ \\
\hline i. Well-being, $\boldsymbol{a}_{i 1}$ & $K_{i 1}$ & $x_{i 11}$ & $x_{i 12}$ & $x_{i 13}$ & $\ldots$ & $x_{i 1 j}$ & $\ldots$ & $x_{i 1 n}$ \\
\hline$\ldots$ & & $\ldots$ & $\ldots$ & $\ldots$ & $\ldots$ & $\ldots$ & $\ldots$ & $\ldots$ \\
\hline \multirow[t]{2}{*}{ c. Maintenance, $\boldsymbol{A}_{\boldsymbol{c} \mathbf{1}}$} & $K_{c 1}$ & $x_{c 11}$ & $x_{c 12}$ & $x_{c 13}$ & $\ldots$ & $x_{c 1 j}$ & $\ldots$ & $x_{c 1 n}$ \\
\hline & \multicolumn{8}{|c|}{ Information related to life cycle of 2 -nd building } \\
\hline 1. Plot, $a_{11}$ & $K_{11}$ & $x_{111}$ & $x_{112}$ & $x_{113}$ & $\ldots$ & $x_{11 j}$ & $\ldots$ & $x_{11 n}$ \\
\hline 2. Building, $\boldsymbol{a}_{21}$ & $K_{21}$ & $x_{211}$ & $x_{212}$ & $x_{213}$ & $\ldots$ & $x_{21 j}$ & $\ldots$ & $x_{21 n}$ \\
\hline$\ldots$ & & $\ldots$ & $\ldots$ & $\ldots$ & $\ldots$ & $\ldots$ & $\ldots$ & $\ldots$ \\
\hline i. Well-being, $\boldsymbol{a}_{\mathrm{i} 1}$ & $K_{i 1}$ & $x_{i 11}$ & $x_{i 12}$ & $x_{i 13}$ & $\ldots$ & $x_{i 1 j}$ & $\ldots$ & $x_{i 1 n}$ \\
\hline$\ldots$ & & $\ldots$ & $\ldots$ & $\ldots$ & $\ldots$ & $\ldots$ & $\ldots$ & $\ldots$ \\
\hline c. Maintenance, $\boldsymbol{a}_{c 2}$ & $K_{c 2}$ & $x_{c 21}$ & $x_{c 22}$ & $x_{c 23}$ & $\ldots$ & $x_{c 2 j}$ & $\ldots$ & $x_{c 2 n}$ \\
\hline \multirow[t]{2}{*}{$\ldots$} & $\ldots$ & $\ldots$ & $\ldots$ & $\ldots$ &. & $\ldots$ & . & $\ldots$ \\
\hline & \multicolumn{8}{|c|}{ Information related to life cycle of p-th building } \\
\hline 1. Plot, $a_{11}$ & $K_{11}$ & $x_{111}$ & $x_{112}$ & $x_{113}$ & $\ldots$ & $x_{11 j}$ & $\ldots$ & $x_{11 n}$ \\
\hline 2. Building, $\boldsymbol{a}_{21}$ & $K_{21}$ & $x_{211}$ & $x_{212}$ & $x_{213}$ & $\ldots$ & $x_{21 j}$ & $\ldots$ & $x_{21 n}$ \\
\hline$\ldots$ & & $\ldots$ & $\ldots$ & $\ldots$ & $\ldots$ & $\ldots$ & $\ldots$ & $\ldots$ \\
\hline i. Well-being, $\boldsymbol{a}_{\boldsymbol{i} \mathbf{1}}$ & $K_{i 1}$ & $x_{i 11}$ & $x_{i 12}$ & $x_{i 13}$ & $\ldots$ & $\boldsymbol{x}_{i 1 j}$ & $\ldots$ & $x_{i 1 n}$ \\
\hline$\ldots$ & & $\ldots$ & $\ldots$ & $\ldots$ & $\ldots$ & $\ldots$ & $\ldots$ & $\ldots$ \\
\hline c. Maintenance, $\boldsymbol{a}_{c p}$ & $\boldsymbol{K}_{c p}$ & $x_{c p 1}$ & $x_{c p 2}$ & $x_{c p 3}$ & $\ldots$ & $\boldsymbol{x}_{c p j}$ & $\ldots$ & $x_{c p n}$ \\
\hline \multirow[t]{2}{*}{$\ldots$} & $\ldots$ & $\ldots$ & $\ldots$ & $\ldots$ &. & $\ldots$ &. & $\ldots$ \\
\hline & \multicolumn{8}{|c|}{ Information related to life cycle of the last $(\mathrm{K})$ building } \\
\hline 1. Plot, $a_{1 p}$ & $K_{1 p}$ & $x_{1 p 1}$ & $x_{1 p 2}$ & $x_{1 p 3}$ & $\ldots$ & $x_{1 p j}$ & $\ldots$ & $x_{1 p n}$ \\
\hline 2. Building, $\boldsymbol{a}_{2 p}$ & $K_{2 p}$ & $x_{2 p 1}$ & $x_{2 p 2}$ & $x_{2 p 3}$ & $\ldots$ & $x_{2 p j}$ & $\ldots$ & $x_{2 p n}$ \\
\hline$\ldots$ & & $\ldots$ & $\ldots$ & $\ldots$ & $\ldots$ & $\ldots$ & $\ldots$ & $\ldots$ \\
\hline i. Well-being, $\boldsymbol{a}_{i p}$ & $\boldsymbol{K}_{i p}$ & $x_{i p 1}$ & $x_{i p 2}$ & $x_{i p 3}$ & $\ldots$ & $\boldsymbol{x}_{i p j}$ & $\ldots$ & $x_{i p n}$ \\
\hline$\ldots$ & & $\ldots$ & $\ldots$ & $\ldots$ & $\ldots$ & $\ldots$ & $\ldots$ & $\ldots$ \\
\hline c. Maintenance, $\boldsymbol{a}_{c p}$ & $\boldsymbol{K}_{c p}$ & $x_{c p 1}$ & $x_{c p 2}$ & $x_{c p 3}$ & $\ldots$ & $\boldsymbol{x}_{c p j}$ & $\ldots$ & $x_{c p n}$ \\
\hline
\end{tabular}

The same applies to paying the money (it depends on whether - this should be done at the present moment or in some years). The above significances of the solutions are determined by using expert, financial analysis and other methods.

The significances should be made compatible in two directions: horizontally (among criteria) and vertically (among solutions). In this way, Table 2.7 may be transformed into a summary decision making table (see Table 2.8) containing all generalized versions and overall related information. 
Table 2.8. Summary decision making table of all generalized versions obtained and overall related conceptual and quantitative information (as example for built environment project)

\begin{tabular}{|c|c|c|c|c|c|c|c|c|}
\hline \multirow{3}{*}{$\begin{array}{l}\text { Built environment } \\
\text { project } \\
\text { (BEP) } \\
\text { versions obtained }\end{array}$} & \multicolumn{8}{|c|}{ Information related to built environment project versions } \\
\hline & \multirow{2}{*}{$\begin{array}{l}\text { Concep- } \\
\text { tual }\end{array}$} & \multicolumn{7}{|c|}{ Quantitative } \\
\hline & & $\begin{array}{l}\text { Cost, } \\
\boldsymbol{X}_{\mathbf{1}}\end{array}$ & $\begin{array}{l}\text { Aesthetics, } \\
\boldsymbol{X}_{\mathbf{2}}\end{array}$ & $\begin{array}{l}\text { Comfortability, } \\
\boldsymbol{X}_{\mathbf{3}}\end{array}$ & $\ldots$ & $X_{j}$ & $\ldots$ & $\begin{array}{l}\text { Means of } \\
\text { transport, } \boldsymbol{X}_{\boldsymbol{n}}\end{array}$ \\
\hline $1 \mathrm{BEP}$ version & $K_{1}$ & $x_{11}$ & $x_{12}$ & $x_{13}$ & $\ldots$ & $x_{1 j}$ & $\ldots$ & $x_{1 n}$ \\
\hline $2 \mathrm{BEP}$ version & $K_{2}$ & $x_{21}$ & $x_{22}$ & $x_{23}$ & $\ldots$ & $x_{2 j}$ & $\ldots$ & $x_{2 n}$ \\
\hline $3 \mathrm{BEP}$ version & $K_{3}$ & $x_{31}$ & $x_{32}$ & $x_{33}$ & $\ldots$ & $x_{3 j}$ & $\ldots$ & $x_{3 n}$ \\
\hline$\ldots$ & & $\ldots$ & $\ldots$ & $\ldots$ & $\ldots$ & $\cdots$ & $\ldots$ & $\ldots$ \\
\hline$i$ BEP version & $K_{i}$ & $x_{i 1}$ & $x_{i 2}$ & $x_{i 3}$ & $\ldots$ & $x_{i j}$ & $\ldots$ & $x_{\text {in }}$ \\
\hline$\ldots$ & & $\ldots$ & $\ldots$ & $\ldots$ & $\ldots$ & $\ldots$ & $\ldots$ & $\ldots$ \\
\hline$K$ BEP version & $K_{K}$ & $x_{K 1}$ & $x_{K 2}$ & $x_{K 3}$ & $\cdots$ & $x_{K j}$ & $\ldots$ & $x_{K n}$ \\
\hline \multicolumn{2}{|c|}{ Significances of criteria } & $q_{1}$ & $q_{2}$ & $q_{3}$ & $\cdots$ & $q_{j}$ & $\ldots$ & $q_{n}$ \\
\hline \multicolumn{2}{|c|}{ Measuring units of criteria } & $L t$ & Points & Points & $\ldots$ & $\ldots$ & $\ldots$ & Points \\
\hline
\end{tabular}

Example discussed above is dedicated to evaluation of the built environment project. The same scenario can be used for other purposes, such as for evaluation of information search results. In this case adequate criteria should be used.

\subsection{A Method of Defining the Utility and Market Value of a Property Adopted for the Intelligent Tutoring System for Built Environment}

As it was discussed in Chapter 2.2.1, significance $Q_{j}$ obtained by using COPRAS method of property $a_{j}$ indicates satisfaction degree of demands and goals pursued by the interested parties - the greater is the $Q_{j}$ the higher is the efficiency of the property (Zavadskas et al. 1994). The utility degree $N_{j}$ (equation 2.6) is determined by comparing the property analysed with the most efficient property. In this case, all the utility degree values related to the property analyzed will be ranged from $0 \%$ to $100 \%$. This will facilitate visual assessment of property efficiency (Zavadskas and Kaklauskas 1996a). 
This method in the Intelligent Tutoring System for Built Environment is applied only for evaluation of built environment projects.

The degrees of utility of the property considered as well as the market value of a property being evaluated are determined in seven following stages.

Stage 1 . The utility degree $N_{j}$ is calculated according to equation (2.6). The degree of utility $N_{j}$ of property $a_{j}$ indicates the level of satisfying the needs of the parties interested in the property. The more goals are achieved and the more important they are, the higher is the degree of the property utility. Since clients are mostly interested in how much more efficient particular property are than the others (which ones can better satisfy their needs), then it is more advisable to use the concept of property utility rather than significance when choosing the most efficient solution (Zavadskas and Kaklauskas 1996a).

A degree of property utility reflects the extent to which the goals pursued by the interested parties are attained. Therefore, it may be used as a basis for determining property market value. The more objectives are attained and the more significant they are the higher will be property degree of utility and its market value.

Thus, having determined in such a way the ratio of degree of utility and market value of property, one can see what complex effect can be obtained by investing money into anyone of the property. There is a complete clarity where it pays better to invest the money and what is the efficiency degree of the investment.

Stage 2 . The efficiency degree $E_{j i}$ of money invested into property $a_{j}$ is calculated. It shows by how many per cent it is better (worse) to invest money into property $a_{j}$ compared with property $a_{i}$. $E_{j i}$ is obtained by comparing the degrees of utility of the property considered:

$$
E_{j i}=N_{j}-N_{i}
$$

The received results are presented as a matrix clearly showing utility differences of the property (see Table 2.9) (Zavadskas and Kaklauskas 1996a).

Stage 3 . The average deviation $k_{j}$ of the utility degree $N_{j}$ of the property $a_{j}$ from the same index of other property $(n-1)$ is being calculated:

$$
k_{j}=\sum_{i=1}^{n} E_{j i}:(n-1) .
$$


Table 2.9. Calculation of average deviations of the property utility degrees (Zavadskas and Kaklauskas 1996a)

\begin{tabular}{|c|c|c|c|c|c|c|}
\hline \multirow[t]{2}{*}{$\begin{array}{l}\text { Property } \\
\text { considered }\end{array}$} & \multicolumn{5}{|c|}{$\begin{array}{l}\text { Utility degree deviation of a proper- } \\
\text { ty analysed compared to other prop- } \\
\text { erty, } \%\end{array}$} & \multirow{2}{*}{$\begin{array}{l}\text { Average deviation } k_{j} \text { of utility degree } N_{j} \\
\text { of property } a_{j} \text { compared to other }(n-1) \\
\text { property, } \%\end{array}$} \\
\hline & $a_{1}$ & $a_{2}$ & $a_{3}$ & $a_{i}$ & $a_{n}$ & \\
\hline $\mathrm{a}_{1}$ & 0 & $E_{12}$ & $E_{13}$ & $\ldots$ & $E_{1 n}$ & $k_{1}$ \\
\hline $\mathrm{a}_{2}$ & $E_{21}$ & 0 & $E_{23}$ & $\ldots$ & $E_{2 n}$ & $k_{2}$ \\
\hline $\mathrm{a}_{3}$ & $E_{31}$ & $E_{32}$ & 0 & $\ldots$ & $E_{3 n}$ & $k_{3}$ \\
\hline$\ldots$ & $\ldots$ & $\ldots$ & $\ldots$ & $\ldots$ & $\ldots$ & $\ldots$ \\
\hline $\mathrm{a}_{j}$ & $E_{j 1}$ & $E_{j 2}$ & $E_{j 3}$ & $\ldots$ & $E_{j n}$ & $k_{j}$ \\
\hline$\ldots$ & $\ldots$ & $\ldots$ & $\ldots$ & $\ldots$ & $\ldots$ & $\ldots$ \\
\hline $\mathrm{a}_{n}$ & $E_{n 1}$ & $E_{n 2}$ & $E_{n 3}$ & $\ldots$ & 0 & $k_{n}$ \\
\hline
\end{tabular}

Stage 4. The development of a grouped decision making matrix for property multiple criteria analysis. The market value of a property being evaluated is calculated according to a block-diagram presented in Fig. 2.4.

At the beginning, a grouped decision making matrix for property multiple criteria analysis is developed (see Table 2.10), the first criterion of which is based on the actual purchasing/selling prices of the property compared and the value of a property being evaluated. The initial value of a property being evaluated is obtained from the following equation:

$$
x_{11}=\sum_{j=2}^{n} x_{1 j}:(n-1) .
$$

In this matrix, a property $a_{1}$ to be evaluated should be assigned the market value $\left(x_{11}-R\right)$. Other comparison standard property $\left(a_{2}-a_{n}\right)$ were sold, their purchasing/selling prices $\left(x_{12}-x_{1 n}\right)$ known. All the values and significances of the criteria relating to other property are also known (see Table 2.10 ).

The problem may be stated as follows: what market value $x_{11}-R$ of evaluated property $a_{1}$ will make it equally competitive on the market with comparison standard property $\left(a_{2}-a_{n}\right)$ ? This may be determined if a complex analysis of the benefits and drawbacks of the property is made. 


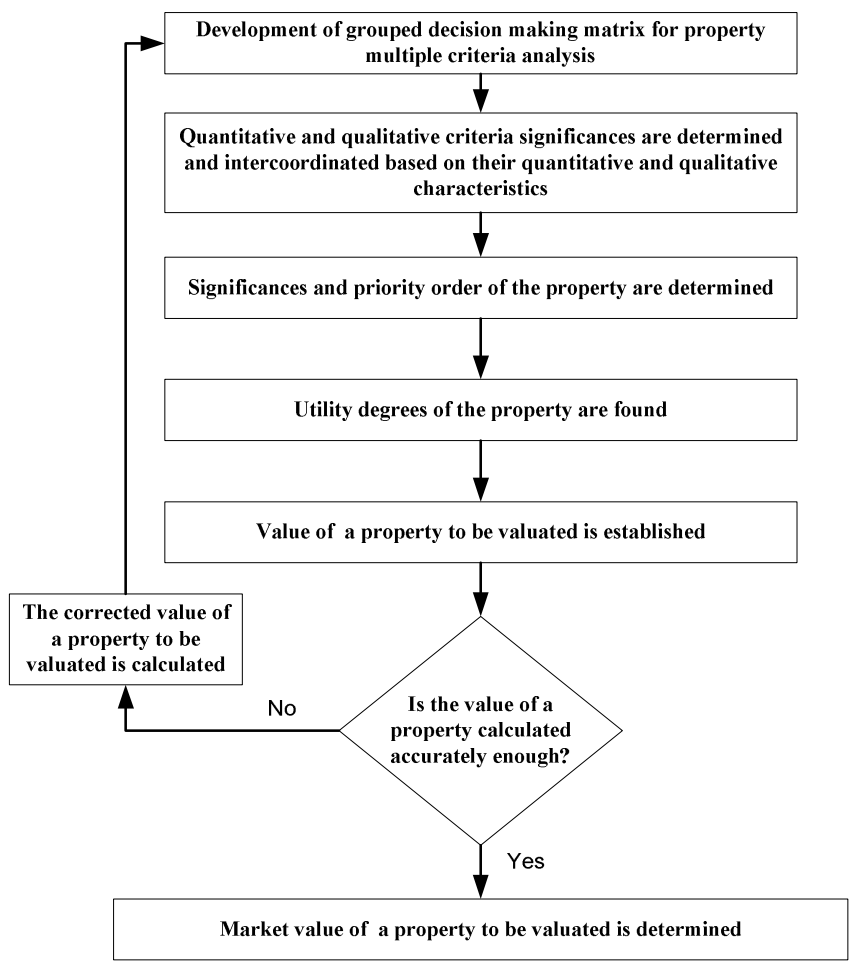

Fig. 2.4. Block-diagram of property market value estimation (Created by author)

Using a grouped decision making matrix (see Table 2.10) and the equations 2.1-2.11 the calculations are made.

Stage 5 . The corrected value $x_{11}-p$ of a property to be evaluated $a_{1}$ is calculated:

$$
x_{11-p}=x_{11} *\left(1+k_{1}: 100\right) .
$$

Stage 6. It is determined whether the corrected value $x_{11}-R$ of a property being evaluated $a_{1}$ had been calculated accurately enough:

$$
\left|k_{1}\right|<s
$$

where $s$ is the accuracy (\%), to be achieved in calculating the market value $x_{11}-p$ of a property $a_{1}$. For example, given $s=0.5 \%$, the number of approximations in calculation will be lower than at $s=0.1 \%$. 
Table 2.10. A grouped decision making matrix for property multiple criteria analysis

\begin{tabular}{|l|l|l|l|l|l|l|l|l|l|}
\hline $\begin{array}{l}\text { Criteria describing the compared } \\
\text { property }\end{array}$ & $*$ & $\begin{array}{l}\text { Signi- } \\
\text { ficance }\end{array}$ & $\begin{array}{l}\text { Measu- } \\
\text { ring } \\
\text { units }\end{array}$ & \multicolumn{5}{|l|}{$\begin{array}{l}\text { Property to be evaluated and com- } \\
\text { parison standard property }\end{array}$} \\
\cline { 4 - 11 } & & & & $a_{1}$ & $a_{2}$ & $\ldots$ & $a_{j}$ & $\ldots$ & $a_{n}$ \\
\hline $\begin{array}{l}\text { 1. Price of a property } a_{1} \text { being } \\
\text { evaluated and actual purchas- } \\
\text { ing/selling prices of comparison } \\
\text { standard property }\left(a_{2}-a_{n}\right)\end{array}$ & $z_{1}$ & $q_{1}$ & $m_{1}$ & $x_{11}$ & $x_{12}$ & $\ldots$ & $x_{1 j}$ & $\ldots$ & $x_{1 n}$ \\
\hline \multirow{5}{*}{$\begin{array}{l}\text { Quantitative } \\
\text { criteria }\end{array}$} & $z_{2}$ & $q_{2}$ & $m_{2}$ & $x_{21}$ & $x_{22}$ & $\ldots$ & $x_{2 j}$ & $\ldots$ & $x_{2 n}$ \\
\hline \multirow{5}{*}{$\begin{array}{l}\text { Qualitative } \\
\text { criteria }\end{array}$} & $\ldots$ & $\ldots$ & $\ldots$ & $\ldots$ & $\ldots$ & $\ldots$ & $\ldots$ & $\ldots$ & $\ldots$ \\
\hline$z_{i}$ & $q_{i}$ & $m_{i}$ & $x_{i 1}$ & $x_{i 2}$ & $\ldots$ & $x_{i j}$ & $\ldots$ & $x_{i n}$ \\
\hline & $\ldots$ & $\ldots$ & $\ldots$ & $\ldots$ & $\ldots$ & $\ldots$ & $\ldots$ & $\ldots$ & $\ldots$ \\
\hline$z_{t}$ & $q_{t}$ & $m_{t}$ & $x_{t 1}$ & $x_{t 2}$ & $\ldots$ & $x_{t j}$ & $\ldots$ & $x_{t n}$ \\
\hline$z_{t+1}$ & $q_{t+1}$ & $m_{t+1}$ & $x_{t+1}$ & $x_{t+12}$ & $\ldots$ & $x_{t+1 j}$ & $\ldots$ & $x_{t+1 n}$ \\
\hline$z_{t+2}$ & $q_{t+2}$ & $m_{t+2}$ & $x_{t+2}$ & $x_{t+2}$ & $\ldots$ & $x_{t+2 j}$ & $\ldots$ & $x_{t+2 n}$ \\
\hline & $\ldots$ & $\ldots$ & $\ldots$ & $\ldots$ & $\ldots$ & $\ldots$ & $\ldots$ & $\ldots$ & $\ldots$ \\
\hline$z_{i}$ & $q_{i}$ & $m_{i}$ & $x_{i 1}$ & $x_{i 2}$ & $\ldots$ & $x_{i j}$ & $\ldots$ & $x_{i n}$ \\
\hline & $\ldots$ & $\ldots$ & $\ldots$ & $\ldots$ & $\ldots$ & $\ldots$ & $\ldots$ & $\ldots$ & $\ldots$ \\
\hline$z_{m}$ & $q_{m}$ & $m_{m}$ & $x_{m 1}$ & $x_{m 2}$ & $\ldots$ & $x_{m j}$ & $\ldots$ & $x_{m n}$ \\
\hline
\end{tabular}

* - The sign $\mathrm{z}_{\mathrm{i}}(+(-))$ indicates that a greater (less) criterion value corresponds to a greater significance for a client

Stage 7. The market value $x_{11}-R$ of a property $a_{1}$ to be evaluated is determined. If inequality 2.13 is satisfied the market value of a property $a_{1}$ may be found as follows:

$$
x_{11-R}=x_{11-p} .
$$

If inequality 2.13 is not satisfied this means that the value of a property being evaluated had not been calculated accurately enough and the approximation cycle should be repeated. In this case, the corrected value $x_{11}=x_{11}-p$ of a property being evaluated is substituted into a grouped decision making matrix of property multiple criteria analysis and the calculations according to the equations 2.1-2.14 should be repeated until the equation 2.13 is satisfied.

Solving the problem of determining the market value $x_{11}-R$ of a property $a_{1}$ being evaluated, which would make it equally competitive on the market compared with the property $\left(a_{2}-a_{n}\right)$ already sold, a particular method of defining the utility degree and market value of a property was suggested. This was based on a complex analysis of all the benefits and drawbacks of the property considered. 
According to this method the property utility degree and the market value of a property being estimated are directly proportional to the system of the criteria adequately describing them and the values and significances of these criteria.

\subsection{Conclusions for Chapter 2}

1. Different multi objective assessment methods were compared and COPRAS method was selected to integrate to components of the Intelligent Tutoring System for Built Environment components.

2. Proposed methods allow to perform:

- Personalized search (when billions learning alternatives can be created and the best is selected);

- Adaptive and personalized learning and teaching (according to the student's curiosity, stress and preferred learning difficulty levels);

- Analysis of billions of alternatives when homeworks, course projects and final works are prepared.

3. Because of easily formulated system of criteria proposed methods allow to take into account the general requirements as well as personal student's criteria. 



\section{Intelligent Tutoring System for Built Environment}

In this chapter general model of Intelligent Tutoring System for Built Environment (ITSBE) is presented. All subsystems integrated in ITSBE are described.

On the thematic of this chapter 5 publications (Kaklauskas et al. 2007b, 2009a, 2010a, 2012, 2013) were published and one patent was obtained (Krutinis et al. 2010).

\subsection{Composition of Intelligent Tutoring System for Built Environment}

The proposed Intelligent Tutoring System for Built Environment integrates 5 submodels:

- User Interface Subsystem Submodel - contains a description of the system user interface. Considering user role in the system, submodel adapts user interface depending on user's needs;

- Expert Knowledge Subsystem Submodel - contains a description of the knowledge and behaviours of the expert; 
- Student Subsystem Submodel - contains descriptions of student knowledge and behaviours, including his or her misconceptions and knowledge gaps;

- Tutoring Subsystem Submodel - contains descriptions of behaviours during testing process;

- Built Environment Computer Learning Subsystem Submodel - contains descriptions of experts' knowledge implementation.

Fig. 3.1 shows the conceptual model of Intelligent Tutoring System for Built Environment (ITSBE) proposed by author.

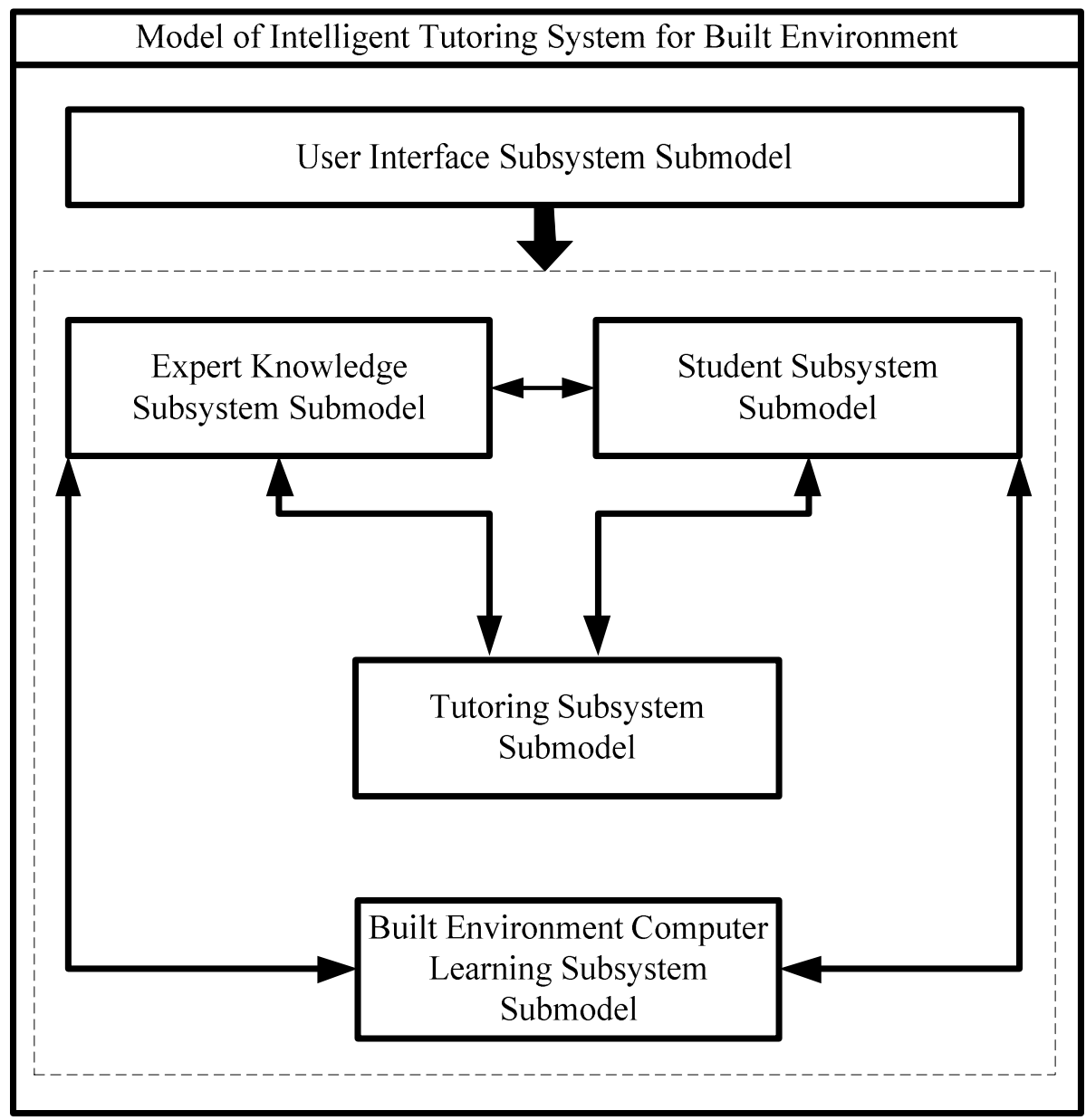

Fig. 3.1. Model of intelligent tutoring system for built environment (Created by author) 
A mismatch between a student's behaviour or knowledge and the expert's presumed behaviour or knowledge is signalled to the ITSBE system, which subsequently takes corrective action. For example, during the testing, system will change the difficulty of questions to lower after 3 mistakes in a row.

\subsubsection{Expert Knowledge Subsystem Submodel}

Fig. 3.2 presents composite parts of expert knowledge subsystem.

\begin{tabular}{|c|c|c|}
\hline \multicolumn{3}{|c|}{ Expert } \\
\hline \multicolumn{3}{|c|}{5} \\
\hline \multicolumn{3}{|c|}{ User Interface } \\
\hline 5 & $\sqrt{5}$ & 5 \\
\hline $\begin{array}{c}\text { Database Managment } \\
\text { Subsystem }\end{array}$ & Equipment Subsystem & Model-base Management System \\
\hline 5 & 5 & 5 \\
\hline Databases: & \begin{tabular}{|l|} 
Consist of: \\
\end{tabular} & - Learning materials alternatives \\
\hline $\begin{array}{l}\text { - Knowledge database; } \\
\text { - Tests database; } \\
\text { - Exams database; } \\
\text { - Historical data statistics } \\
\text { database; }\end{array}$ & $\begin{array}{l}\text { - Data input } \\
\text { equipment; }\end{array}$ & $\begin{array}{l}\text { - Examination alternatives } \\
\text { developing submodel; } \\
\text { - Self-assessment Adjustment } \\
\text { submodel; } \\
\text { - Recommendation providing } \\
\text { submodel. }\end{array}$ \\
\hline
\end{tabular}

Fig. 3.2. Composite parts of expert knowledge subsystem (Created by author)

Subsystem includes four databases: Knowledge database, Tests database, Exams database and Historical data statistics database.

The Knowledge database contains teaching material, teaching material priority information, difficulty level of material, importance level of material and connection information within topics. All primary parameters must be given by field experts. Each part have 4 parameters: learning difficulty in the scope of a topic, learning difficulty in the scope of a module, significance in the scope of a topic, significance in the scope of a module. Using this parameters intelligent tutor is able to moderate teaching and self-testing processes.

In Fig. 3.3 main tables that contain teaching content are shown. All teaching materials must be assigned to one of the subtopics. Each entry has its own prioritization; it helps to manage content appearance for users. In case of deletion, record goes to archive; it will not appear for users but will be available for historical data analysis. 


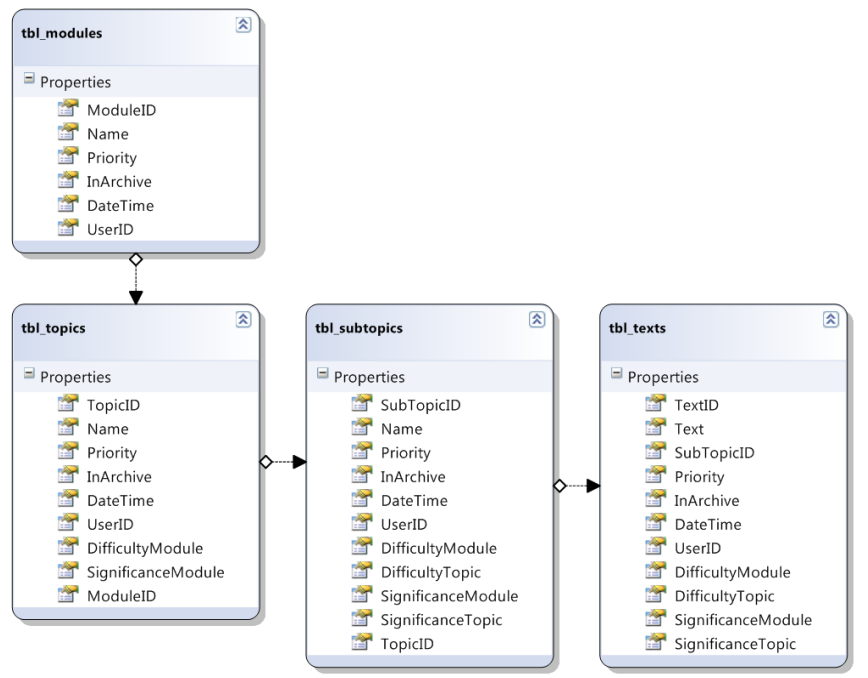

Fig. 3.3. Part of the knowledge database scheme (Created by author)

The Tests database contains following information: questions according to modules and topics, question difficulty in the scope of a module, question difficulty in the scope of a topic, possible answers to questions, correct answers in connection to the explanation material and evaluation of the correctness of possible answer versions.

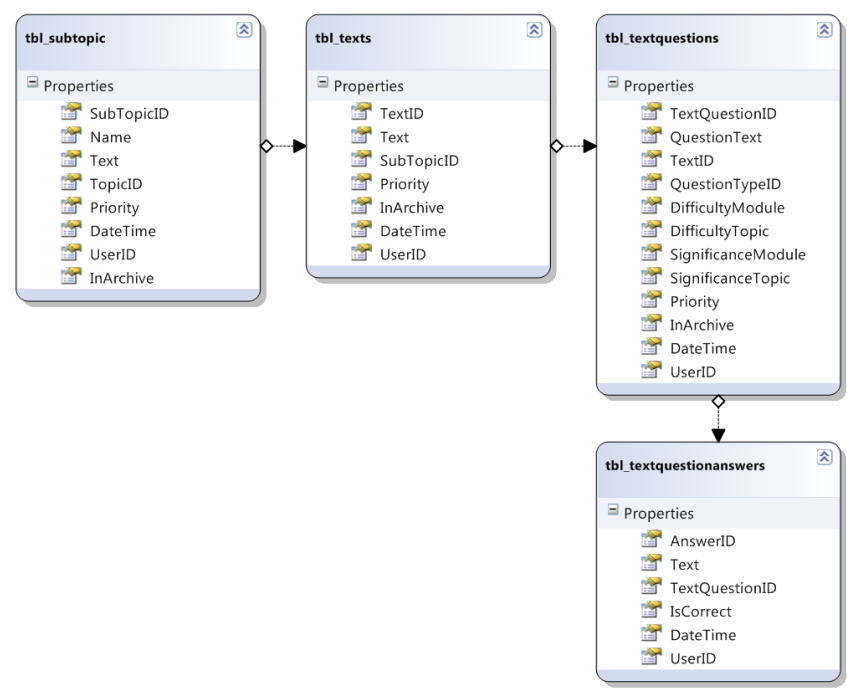

Fig. 3.4. Part of the tests database scheme (Created by author) 
Tests database scheme can be found in Fig. 3.4. Connection of questions to teaching material allows the system to propose what to learn in case of failure. Tests can include video and audio material. Depending on test type tests can have one or more correct answers.

The Exams database (see Fig. 3.5) contains information about exams questions' collections, questions answers, questions difficulty levels, evaluation of the correctness of possible answer versions and correct answers explanations.

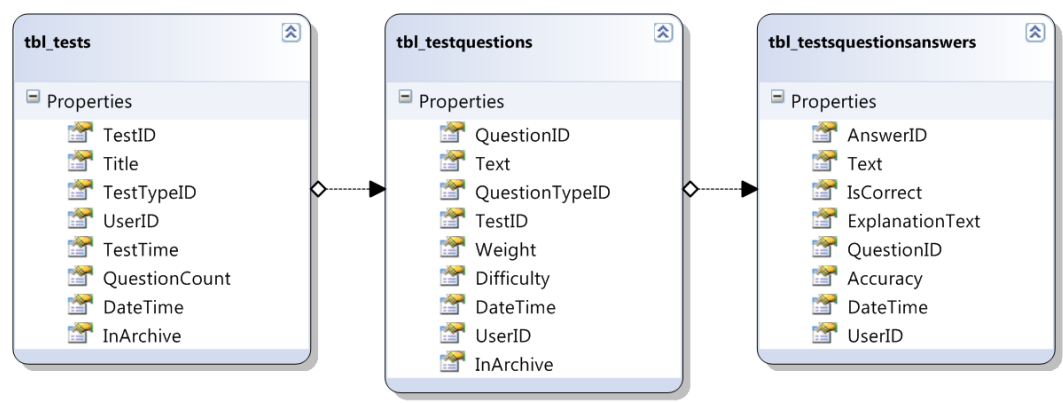

Fig. 3.5. Part of the exams database scheme (Created by author)

Questions have they own weight and difficulty. Weight can be changed for every exam. Difficulty is set by expert tutor, but in future can be recalculated by using statistical information.

Historical data statistics database (see Fig. 3.6.) contains behaviour information collected during tests and exams. Personalized and general data about time intervals, questions difficulty levels, mistakes and correct answers are collected for future use in tutoring process.

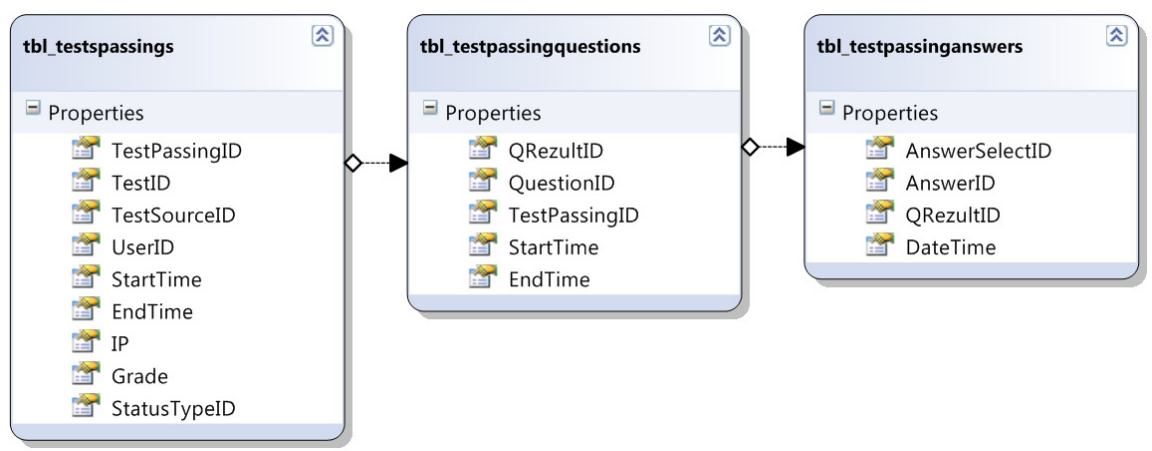

Fig. 3.6. Part of the historical data statistic database scheme (Created by author) 
Database contains not only exam mark and user information, but additionally information of answer changes is collected.

The Model-base consists of four submodels: Learning materials' alternatives developing submodel, Examination alternatives developing submodel, Self-assessment adjustment submodel, Submodel of providing recommendations.

Learning materials' alternatives developing submodel generates learning plans. Submodel is based on accumulated information from self-assessment and historical trends determining submodels. General learning plan can be changed considering student's preferences and trends information gathered during learning, testing and exams processes. It gives possibility for student to get personalized learning material and tests questions.

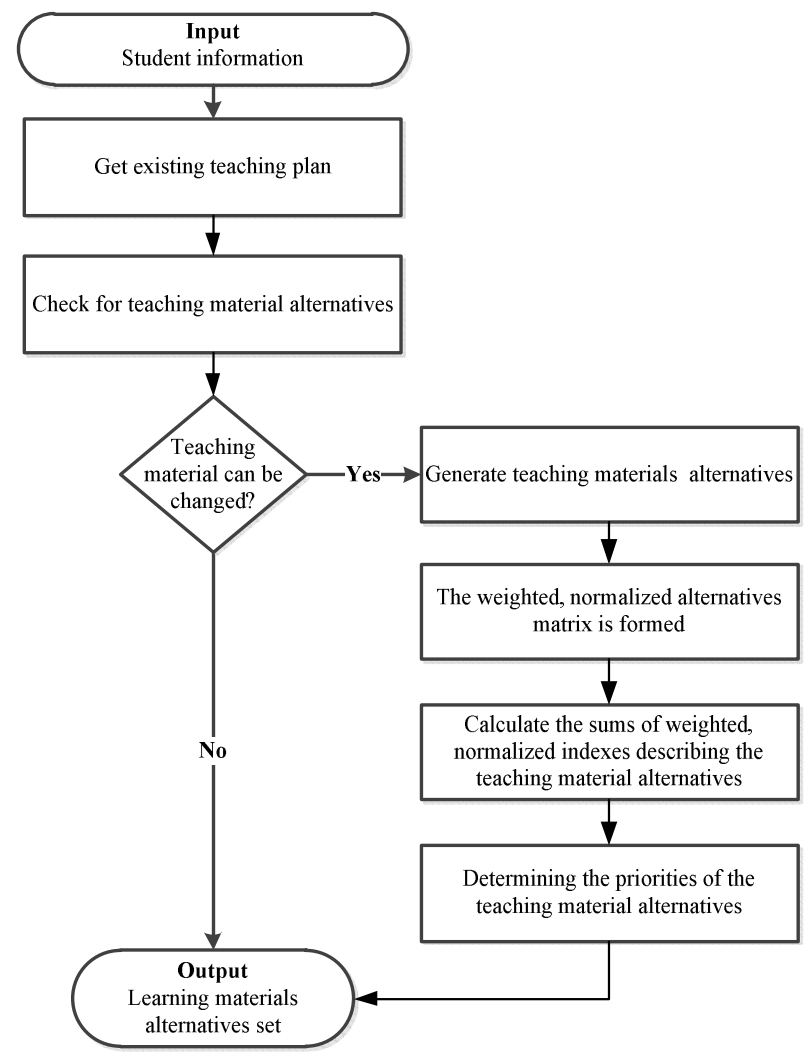

Fig. 3.7. Learning materials alternatives developing submodel (Created by author) 
Learning materials' alternatives developing submodel (see Fig. 3.7) uses student information for development of learning materials' alternatives. In case where no alternatives are for given material, model is returning to default learning material set. If it is possible to generate alternatives of learning material sets, subsystem proposes for student to choose one of them. At first place it will be the best set according to the personal information that was given and possible teaching materials' alternatives from knowledge base.

Examination alternatives developing submodel generates exams questionnaires and self controlling tests for subjects. Considering expert requirements for exam such as questions count, questions difficulty level and subjects from where questions must be taken, alternatives of exams questionnaires can be developed. Tests alternatives for subjects or for the whole submodels are developed considering personal parameters of the user. In order to correct mistakes, a Submodel of providing recommendations is used.

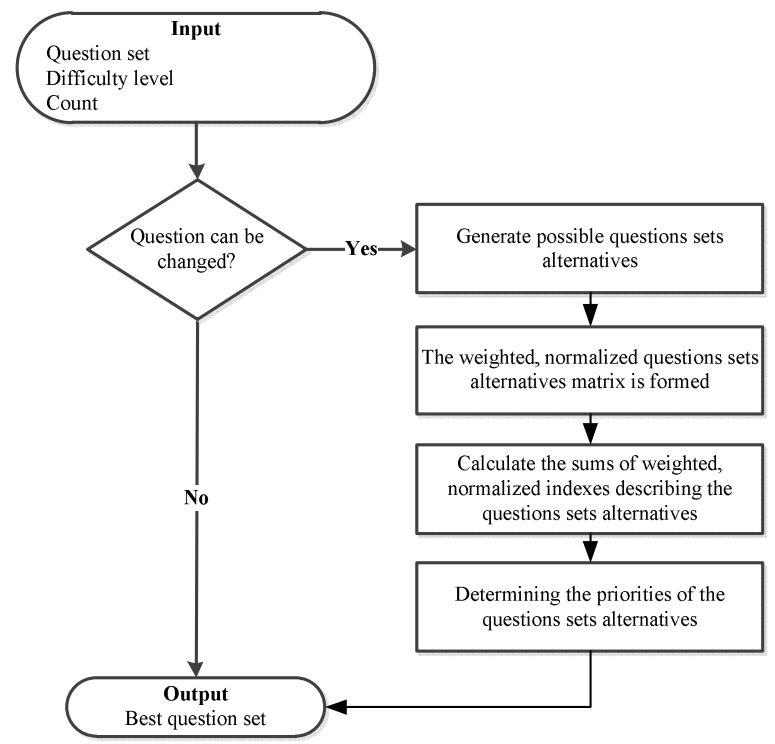

Fig. 3.8. Examination alternatives developing submodel (Created by author)

Personalised examination questions set can be generated in case when it is possible. During knowledge testing student will get best set of questions according to difficulty level. Questions are taken from topics that student is learning or from specified exam questions set, that was prepared by a tutor.

Self-assessment adjustment submodel is used, if it is possible, for controlling testing process considering personal preferences of student. Depending on 
received information on preferred difficulty level, preferred subjects and passed exams requirements for tests are developed (see Fig. 3.9).

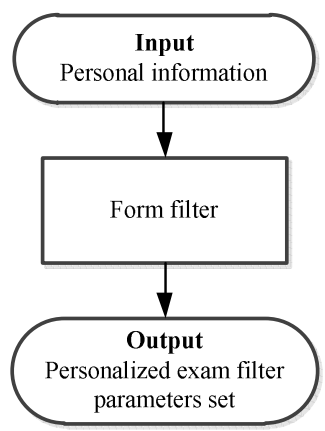

Fig. 3.9. Self-assessment adjustment submodel (Created by author)

For dealing with knowledge base personalized filter can be created. After passing specific topics or exams, system is able to create personalized filter for student that will help in future to deal with teaching materials and tests.

Submodel of providing recommendations explains why one or another answer is incorrect and offers to use certain additional literature to clarify the incorrectly answered questions. Additionally model can show areas of improvement to the tutor of a module (see Fig. 3.10).

Failed questions can be reviewed by the system and tutor to specify why students cannot deal with them. There can be few reasons that can mater. For example, question was added by mistake to wrong teaching material; question difficulty was to low and must be increased; teaching material and additional links must be edited and updated to give more clearance for the students.

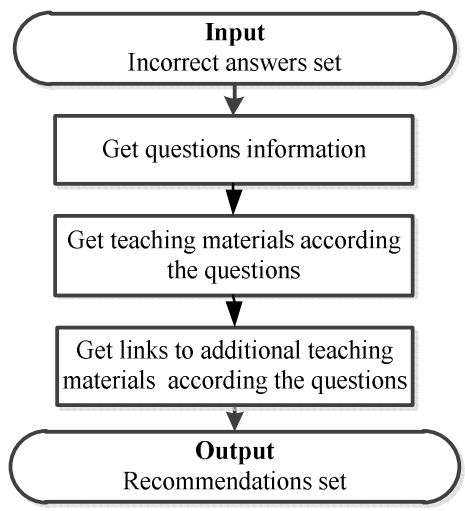

Fig. 3.10. Submodel of providing recommendations (Created by author) 


\subsubsection{Student Subsystem Submodel}

The main parts of Student Subsystem Submodel are presented in Fig. 3.11.

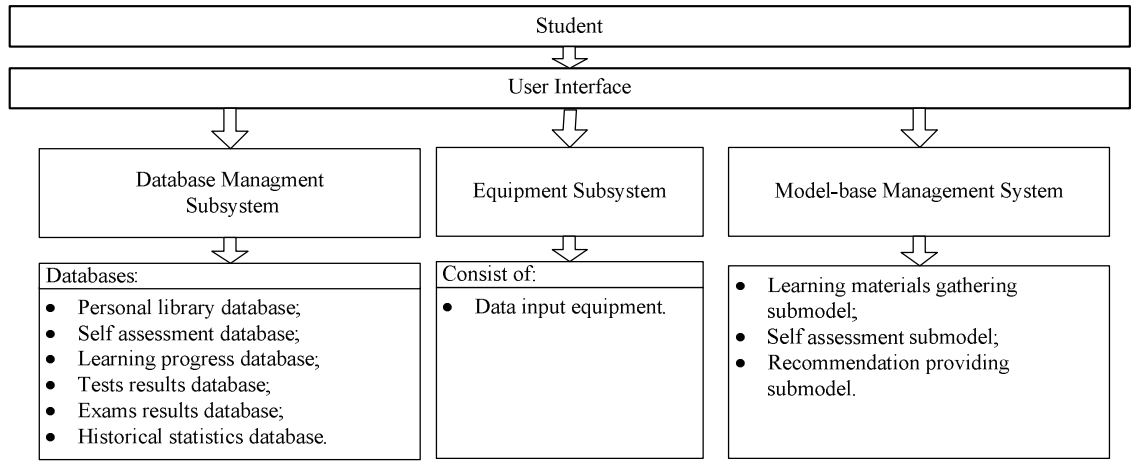

Fig. 3.11. Composite parts of student subsystem (Created by author)

The subsystem contains: Personal library database, Self-assessment database, Learning progress database, Tests results database, Exams results database, Historical statistics database.

Personal library database contains links to student teaching material and personalized teaching material gathered during testing, teaching or search.

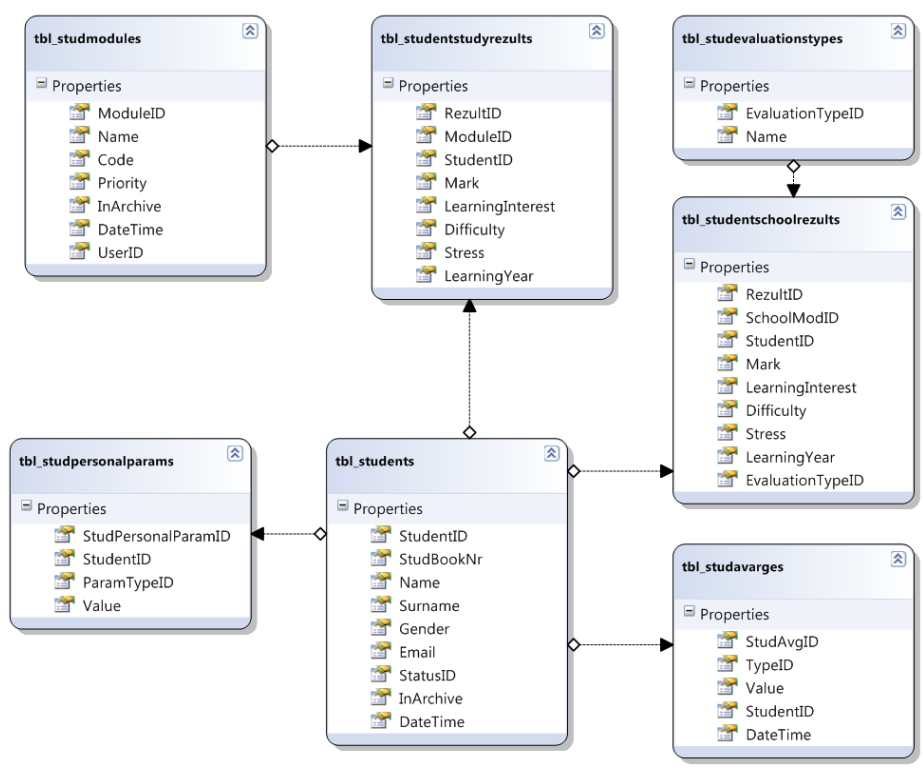

Fig. 3.12. Part of the self assessment database scheme (Created by author) 
Self-assessment database (see Fig 3.12) contains student parameters selected from given options. Two main parameters are preferred difficulty level and learning productivity.

Information about main parameters of student is expanded with historical achievements in school and university. That helps system to take personalized approach for teaching material delivery. Part of this data is gathered when student is passing special survey in the system.

Learning progress database contains information on achievements during learning process (see Fig. 3.13).

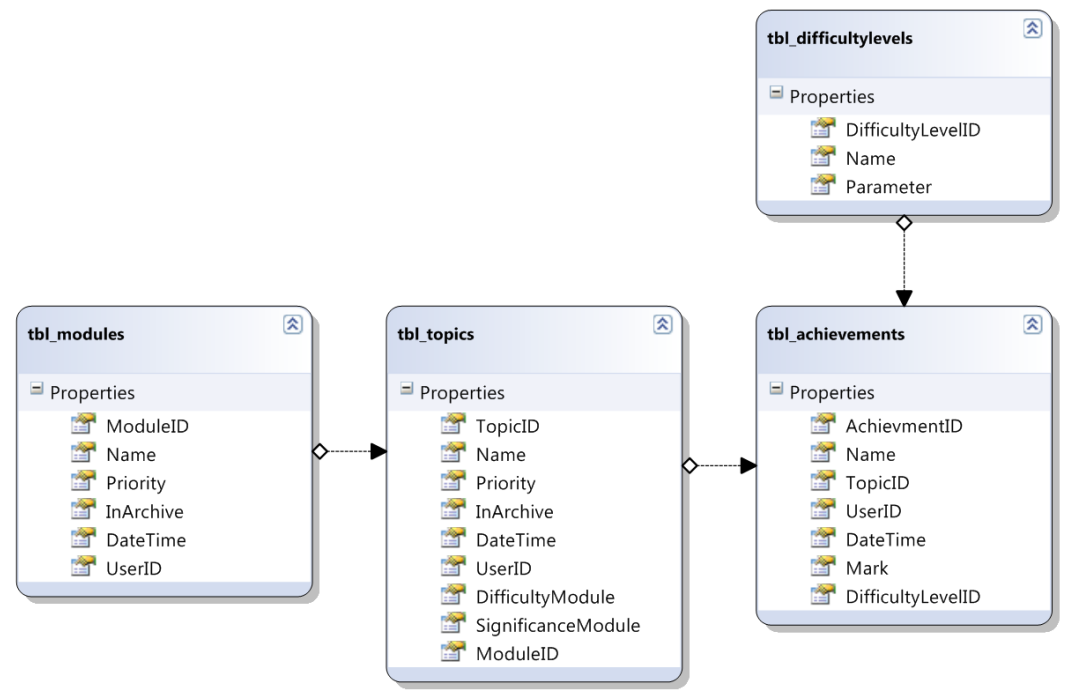

Fig. 3.13. Part of the learning progress database scheme (Created by author)

Depending on success rate and passed tests count, user can get special achievement mark. Achievements can be moderated by tutors in their topics. Passing of self-assessment tests additionally motivates the student.

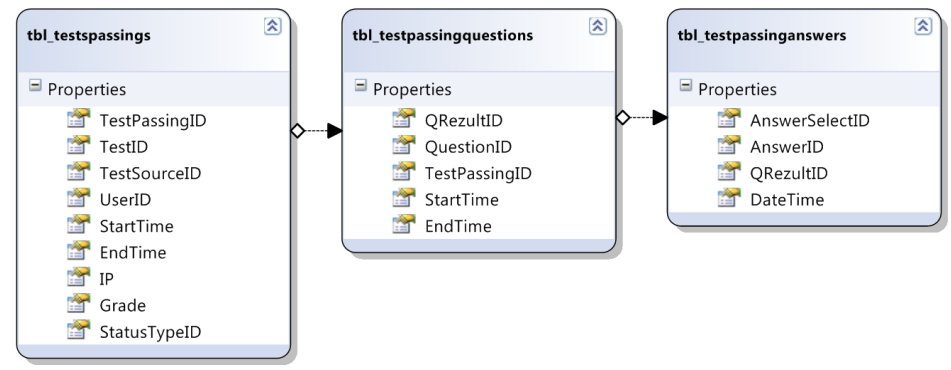

Fig. 3.14. Part of the tests results database scheme (Created by author) 
Tests results database contains results from all test types that student took during learning period (see Fig. 3.14).

For future analysis all passed tests by student are saved and can be reached by user for review in any time. User can create his own test from failed questions. Student is also able to save teaching material proposed by tutor to his own library for future study.

Exams results database contains results from all exams that student had passed or failed during learning period (see Fig. 3.15).

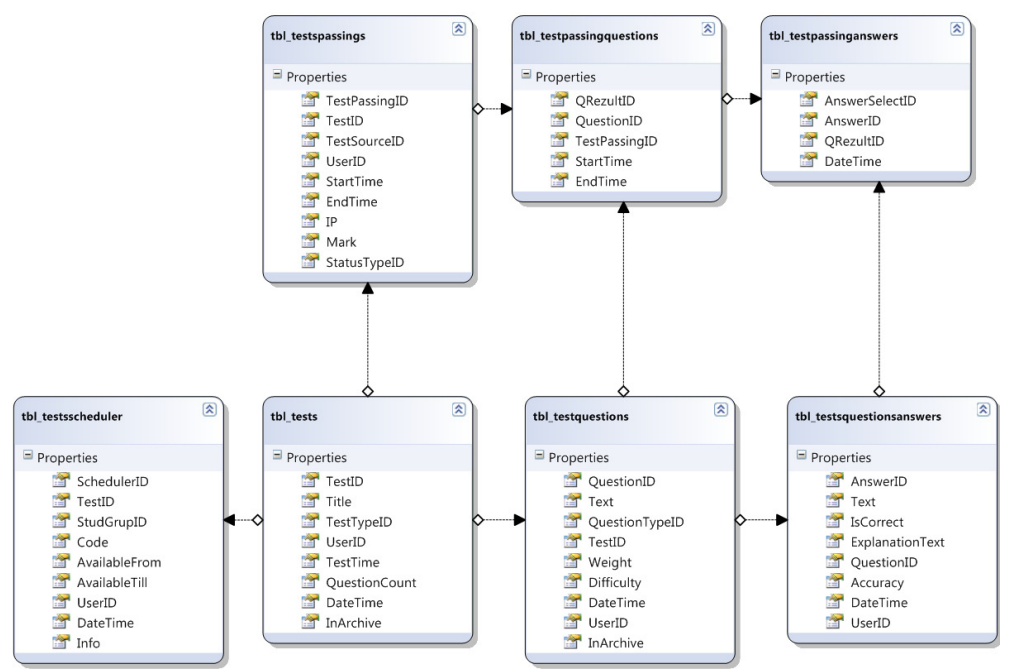

Fig. 3.15. Part of the exams results database scheme (Created by author)

Exams can be assigned for students' groups and can be passed in time period assigned by tutor. All information about test passing can be reviewed by student.

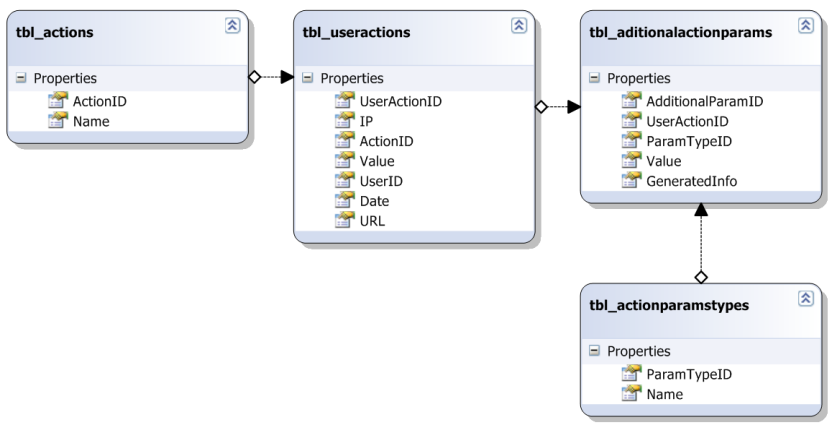

Fig. 3.16. Part of the historical statistics database scheme (Created by author) 
Historical statistics database considers student actions in system. This data can be used to determinate failures in learning materials and tests.

In Fig. 3.16 main tables that contain historical statistic information are shown. Depending on user action type, information is gathered and saved with owner information.

The Model-base consists of three submodels: Learning materials gathering submodel, Self-assessment submodel, Submodel of providing recommendations.

Learning materials gathering submodel describes how learning material can be extracted for future reuse. Submodel uses output of Self-assessment submodel for material search and Submodel of providing recommendations to gather material for failed questions after test (see Fig. 3.17).

Learning materials gathering submodel helps student to search and collect teaching materials according topics or keywords. Additionally, search can be done considering personalized filter parameters. In case of search for specific topic information, subsystem will collect full information on the topic or specific parts that are needed for failed question explanation. In case of free search alternatives of teaching materials will be acquired according keywords. Before generating alternatives they will be filtered by personalized parameters. Set of learning materials' alternatives will be given for student for further use.

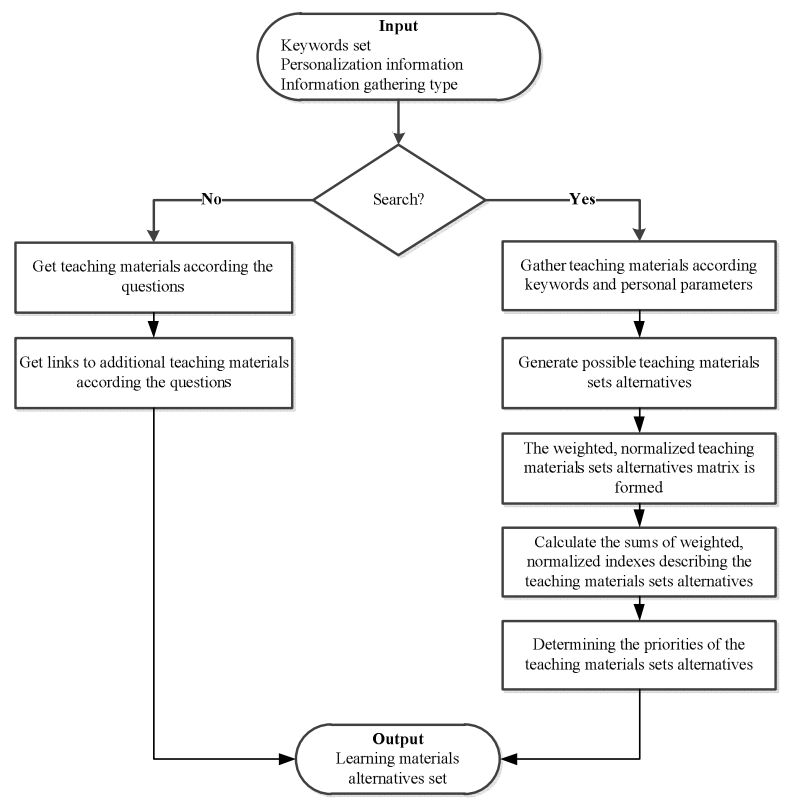

Fig. 3.17. Learning materials gathering submodel (Created by author) 
COPRAS method (see Chapter 2) can be successfully applied for forming search results. There are many methods for gathering information from text sources, but it can be very difficult to manage priority of search results. COPRAS can be optimal solution to deal with this problem. Fig. 3.18 shows activity diagram for search of teaching material.

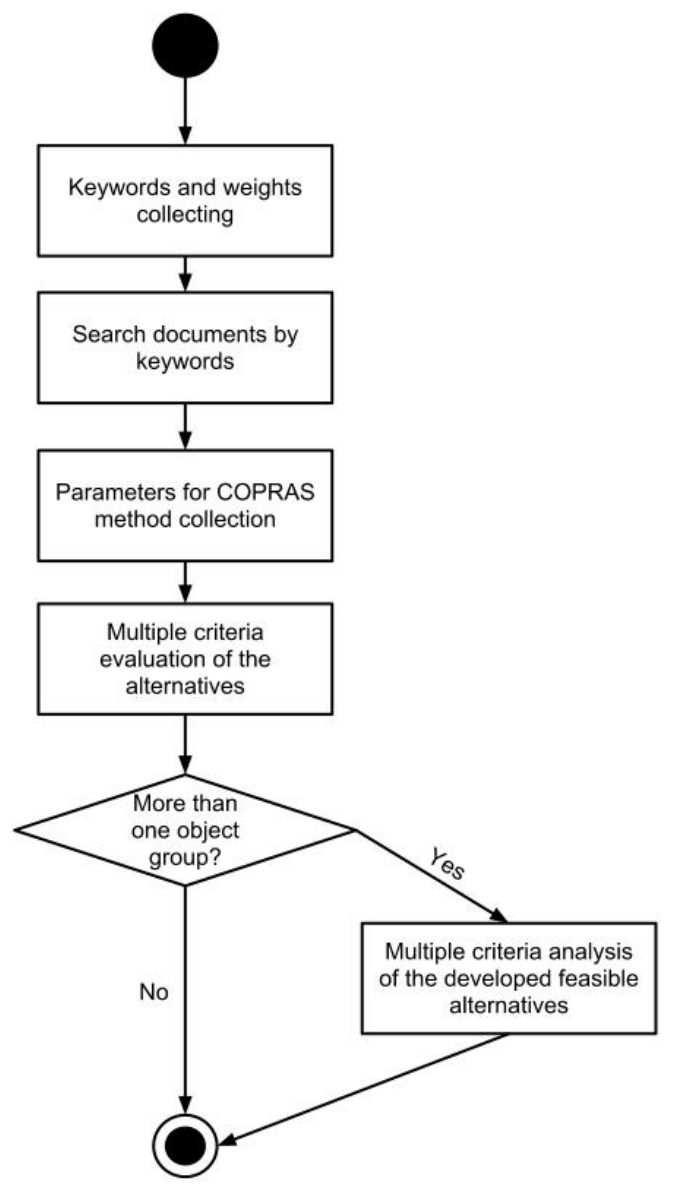

Fig. 3.18. Multiple criteria complex proportional evaluation method algorithm (Created by author)

Forming of search results that depend only on texts' priority is not very complicated task, but in case when multi-variant analysis in real time is needed, it is necessary to manage huge data flow. Dealing with that problem suspension of calculations and cashing are used. 
Self-assessment submodel determines parameters for personalizing of learning and testing processes. It allows to moderate difficulty and content appearance (see Fig. 3.19).

Student can form personalized filter by giving as much personal information as he can. Some parameters can be temporary, for example, preferred difficulty level. Constant parameters such as passed exams or teaching materials will help to arrange optimal learning plan.

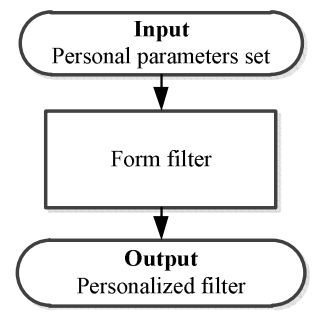

Fig. 3.19. Self-assessment submodel (Created by author)

Submodel of providing recommendations explains why one or another answer is incorrect and offers to use certain additional literature to clarify the incorrectly answered questions. During development of built environment project it shows errors and mistakes of user and leading him to creation of successful project (see Fig. 3.20).

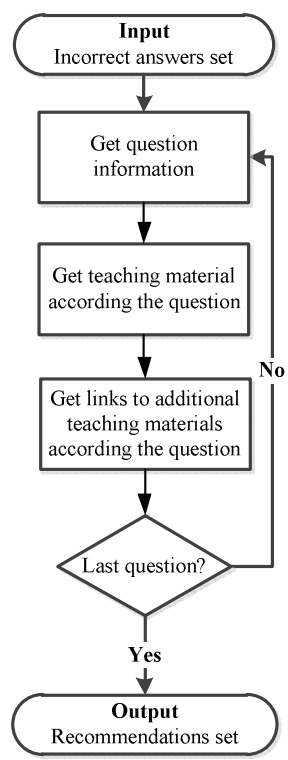

Fig. 3.20. Submodel of providing recommendations (Created by author) 
After each examination it is necessary to get information on failed questions. Subsystem allows getting explanations on failed attempts to pass question. Student can save recommendation results to his personal library for future studies and take re-examination of problematic parts.

\subsubsection{Tutoring Subsystem Submodel}

Composite parts of Tutoring Subsystem are provided in Figure 3.21.

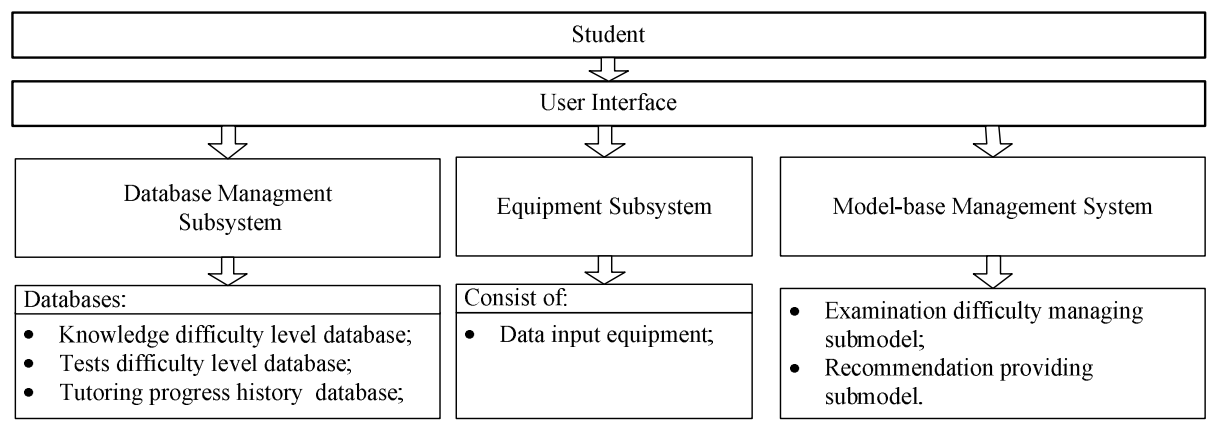

Fig. 3.21. Composite parts of tutoring subsystem (Created by author)

The database contains: Knowledge difficulty level database, Tests difficulty level database, Tutoring progress history database.

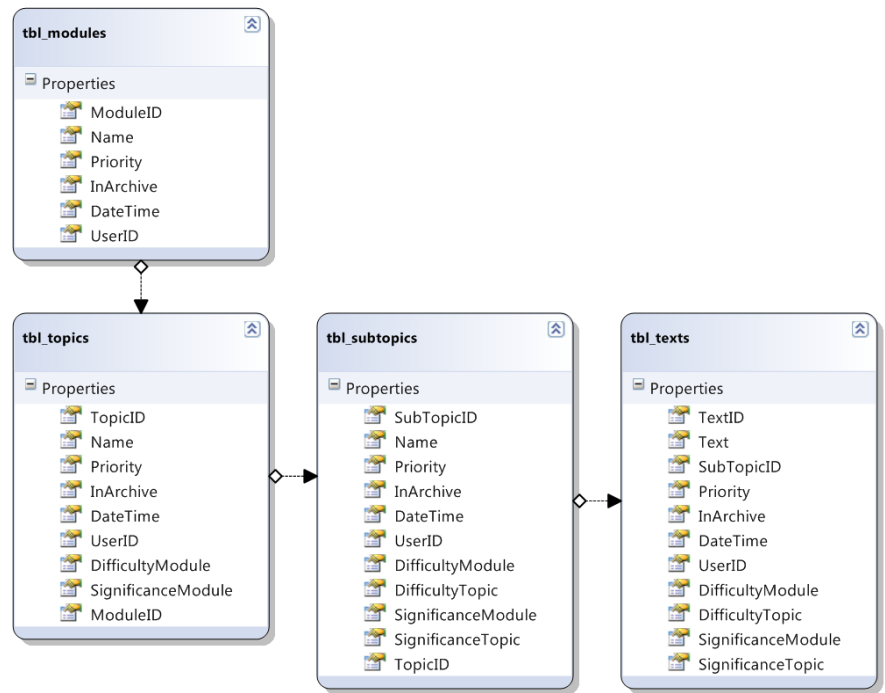

Fig. 3.22. The knowledge difficulty levels database scheme (Created by author) 
Knowledge difficulty level database contains difficulty levels of teaching material determined by expert (see Fig. 3.22).

Each teaching material has difficulty value in topic and module. Depending on these values learning process can be managed by giving easer or harder material for future study. Initial difficulty level is set by topic expert, but in future it can be revised by system.

Tests difficulty level database contains difficulty levels for question collections determined by expert (see Fig. 3.23).

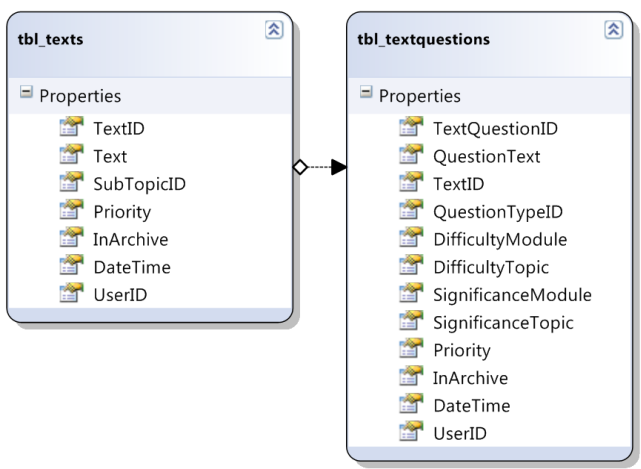

Fig. 3.23. Part of the tests difficulty levels database scheme (Created by author)

Tutor is able to assign specific question with different difficulty levels for every teaching material. During tutoring process system arranges order of questions considering these values. Questions used for self-assessment test additionally can be filtered by filter personalized by student.

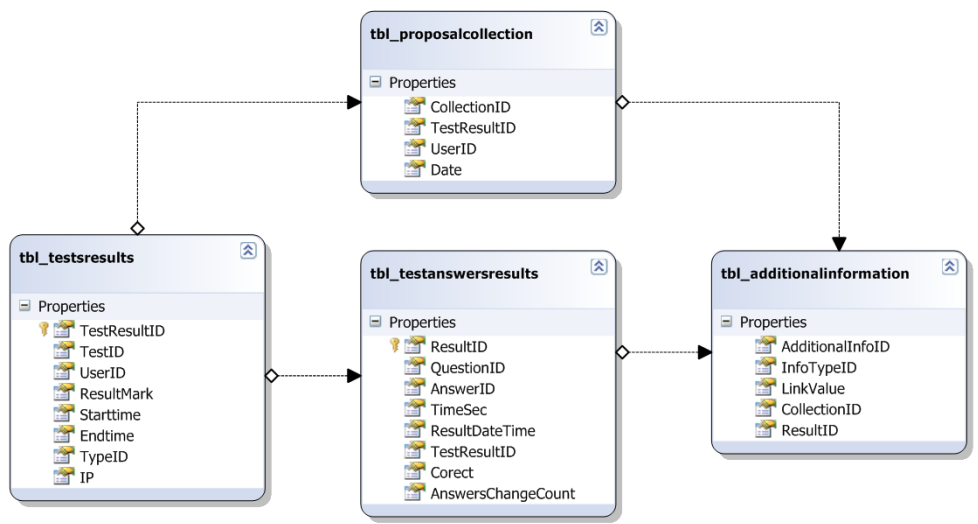

Fig. 3.24. Part of the tutoring progress history database scheme

(Created by author) 
Tutoring progress history database collects information about proposed problem solving methods and users behaviour (see Fig. 3.24).

In Fig. 3.24 main tables that contain information of tutoring progress history levels are shown. During tutoring process system can change difficulty level, give additional information for user or propose failure solving solution. All this information is saved for future analysis.

The Model-base of subsystem consists of two submodels: Examination difficulty managing submodel, Submodel of providing recommendations.

Examination difficulty managing submodel depending on input parameters can change difficulty level of the given test. In case of large amount of failures model can end testing (see Fig. 3.25).

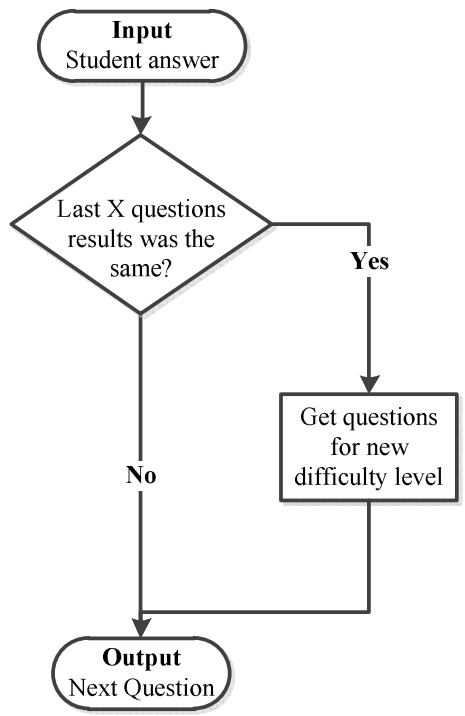

Fig. 3.25. Examination difficulty managing submodel (Created by author)

During examination subsystem can regenerate questions according to new difficulty level. Tutor can manage failed or passed questions count for change of difficulty level. After examination student will get summarized information about difficulty changes and difficulty levels of passed questions. During self controlling tests student is able to manage difficulty level by personalizing test process or let the system to take care of that.

The main part of tutoring process is to collect primary information about the student. That information will help to determine starting difficulty of tutoring and material that needs to be filtered. User can manually choose starting position. 


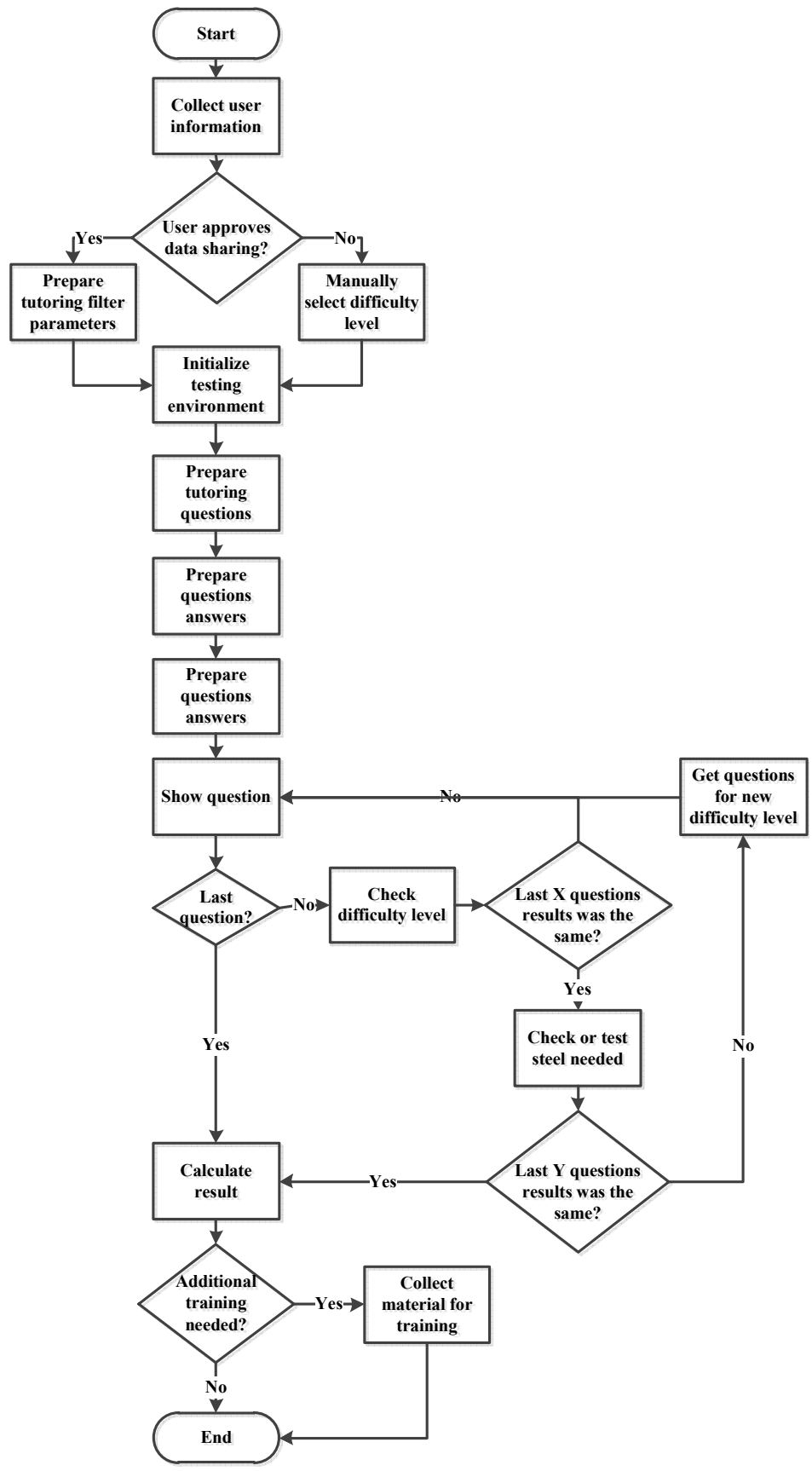

Fig. 3.26. Intelligent tutoring system for built environment examination process algorithm (Created by author) 
Depending on different filters, questions are collected and prepared for user. Each time questions are prepared in random sequence; sequences of answers are also defined randomly. During the test, difficulty level can be changed; it depends on test achievements. Test administrator can manage count of correct or incorrect answers in order to raise or lower difficulty, additionally, test can be ended after few answers. If difficulty level is changed, remaining new questions are prepared. When test is finished, user is getting mark with wrong answers explanations. Basing on wrong answers, teaching material is prepared. User can save it for future studies (see Fig. 3.26).

Submodel of providing recommendations explains why one or another answer is incorrect and offers to use certain teaching material to clarify the incorrectly answered questions. In order to correct gaps in knowledge new learning plan can be proposed to avoid errors in future (see Fig. 3.27).

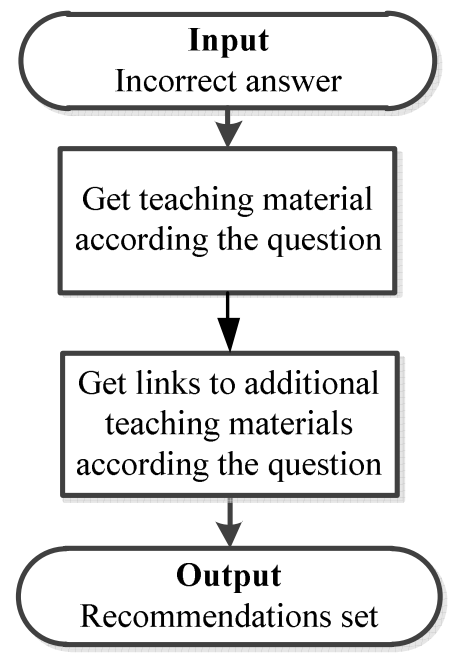

Fig. 3.27. Submodel of providing recommendations (Created by author)

After each test or exam explanations of answers are provided. Depending on available teaching materials sources, teaching material according to the question is provided with additional links. By using additional links subsystem it is possible to recommend teaching material before learning specific topic and after fully passed examination. 


\subsubsection{Built Environment Computer Learning Subsystem Submodel}

Composite parts of Built Environment Computer Learning Subsystem (BECLS) are shown below (see Fig. 3.28).

\begin{tabular}{|c|c|c|}
\hline \multicolumn{3}{|c|}{ Student } \\
\hline & 55 & \\
\hline \multicolumn{3}{|c|}{ User Interface } \\
\hline 5 & 5 & 5 \\
\hline $\begin{array}{l}\text { Database Managment } \\
\text { Subsystem }\end{array}$ & $\begin{array}{l}\text { Equipment } \\
\text { Subsystem }\end{array}$ & Model-base Management System \\
\hline 5 & 5 & 5 \\
\hline Databases: & Consist of: & \\
\hline $\begin{array}{l}\text { - } \begin{array}{l}\text { Experts developed projects templates } \\
\text { database; }\end{array} \\
\text { - } \\
\text { - Student developed projects database; } \\
\text { Graphical database; }\end{array}$ & $\begin{array}{l}\text { - Data input } \\
\text { equipment; }\end{array}$ & $\begin{array}{l}\text { significance and priority of a built } \\
\text { environment project alternatives; } \\
\text { - Submodel of multiple criteria multivariant } \\
\text { design of a built environment project; } \\
\text { - Submodel for defining market value of a } \\
\text { built environment project; } \\
\text { - Submodel for generating the alternative } \\
\text { variants of a built environment project; } \\
\text { - Submodel for determining project utility } \\
\text { degree; } \\
\text { - Submodel of providing recommendations; } \\
\text { - Error check submodel. }\end{array}$ \\
\hline
\end{tabular}

Fig. 3.28. Composite parts of built environment computer learning subsystem (Created by author)

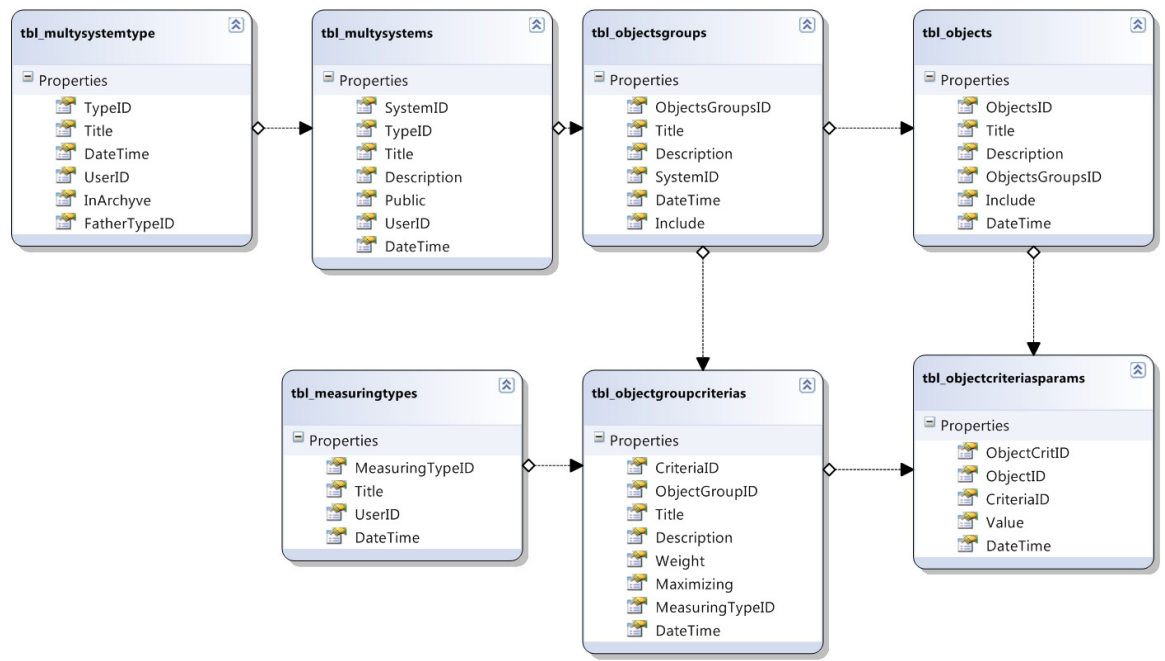

Fig. 3.29. Part of the experts" developed projects' database scheme

(Created by author) 
The database contains of Experts developed projects' templates database, Student developed projects' database, Graphical database.

Projects' templates database developed by experts contains of templates created by experts for reuse in personal student environment. Collected criteria templates can be used for quick evaluation of projects' alternatives (see Fig. 3.29).

All expert created systems can be used to solve specific problem in the field of built environment. Additionally, they can be exported to user zone for future development.

Projects' database developed by students contains of built environment projects with criteria, weights of criteria and objects used for alternatives calculations created by students (see Fig. 3.30).

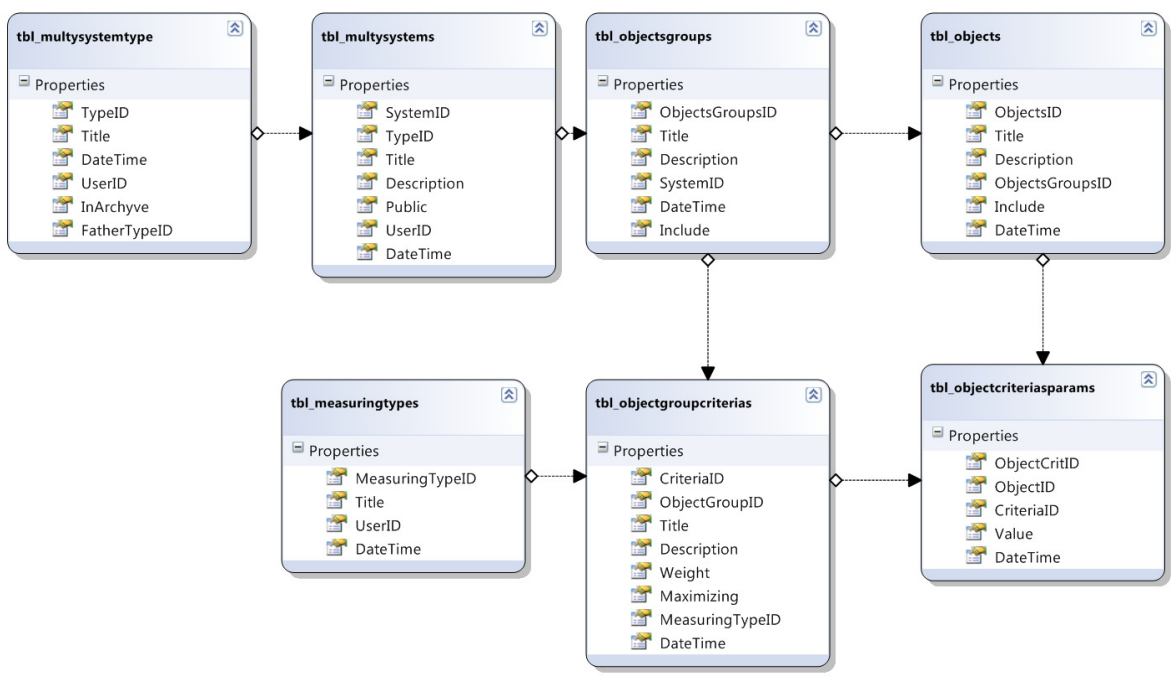

Fig. 3.30. Part of the student developed projects' database scheme (Created by author)

Student can create his own "empty project" and fill all parts one by one, or he/she can use expert created projects' templates and on their basis develop personalized projects. Created projects can be reused or shared with other users.

Graphical database contains of shared and personal graphic elements to maintain computer learning objects of built environment (see Fig. 3.31).

Graphical elements used in students' and experts' projects are saved in these tables. Default graphical elements can be used in case when user doesn't want to use his own. 


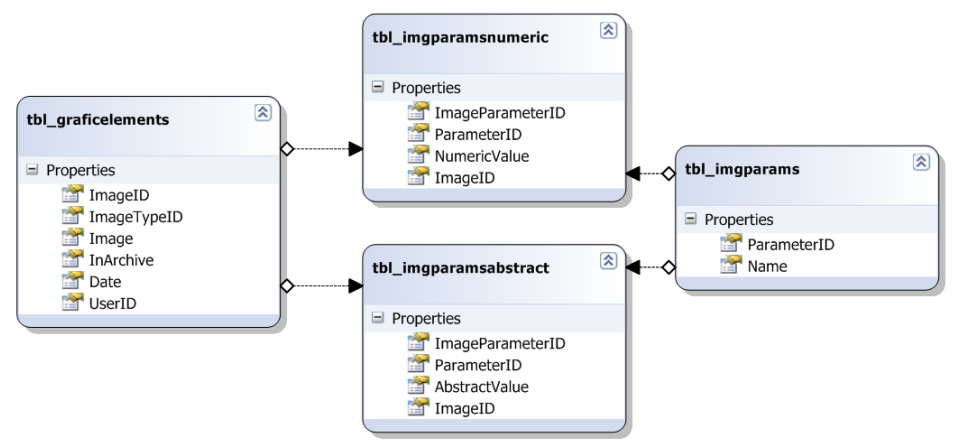

Fig. 3.31. Part of the graphical database scheme (Created by author)

The Model-base consists of seven models: Submodel for determination of the significance and priority of a built environment project alternatives, Submodel of multiple criteria multivariant design of a built environment project, Submodel for defining market value of a built environment project, Submodel for generating the alternative variants of a built environment project, Submodel for determining project utility degree, Submodel of providing recommendations, Error check submodel.

Submodel for determination of the significance and priority of a built environment project alternatives uses the method explained in Chapter 2.2.1.

Submodel of multiple criteria multivariant design of a built environment project uses the method explained in Chapter 2.2.2.

Submodel for defining market value of a built environment project uses the method explained in Chapter 2.2.3.

Submodel for generating the alternative variants of a built environment project generates all possible alternatives of a project (Fig. 3.32).

System administrator is able to manage maximum variants count generated by the system. Variations count of the projects may be determined from the following expression:

$$
K=\prod_{i=1}^{c} p_{i},
$$

where: $c$ is the number of objects groups; $p_{i}$ is the number of the $i$ variants of every objects groups used in developing a built environment project. For example, if in determining possible building life cycle alternative versions 10 alternatives are considered for any of 10 solutions, then, according to equation (3.1) 10 billion variants will be obtained. It is evident that in this and similar cases it is hardly possible and reasonable to analyse all the versions from various perspectives. Therefore, it is advisable to reduce their number as follows. By using mul- 
tiple criteria analysis methods most efficient versions should be chosen from every solution for further consideration. In this way, inefficient variants are being removed.

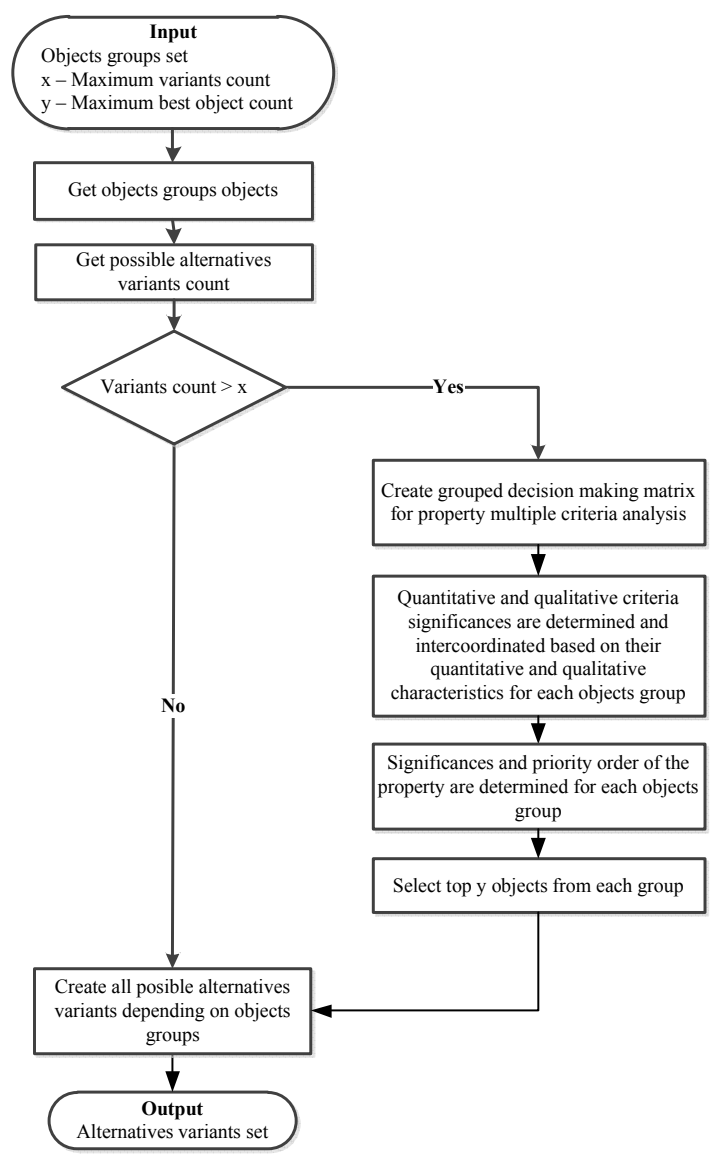

Fig. 3.32. Submodel for developing the alternative variants of a built environment project (Created by author)

Submodel for determining project utility degree considering input information for each project alternative calculates utility degree.

The degree of project utility is determined by comparing the analysed project with the most efficient project. In this case, all the utility degree values related to the project analysed will range from $0 \%$ to $100 \%$. This will facilitate a visual assessment of the project's efficiency (see Fig. 3.33). 


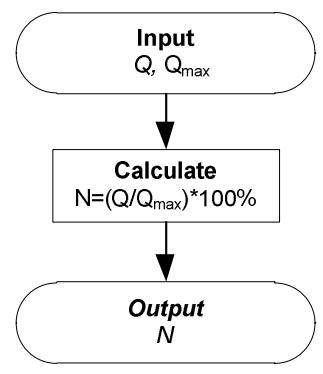

Fig. 3.33. Submodel for determining project utility degree (Created by author)

The formula used in submodel for calculating each alternative utility degree $N_{j}$ is following:

$$
N_{j}=\frac{Q_{j}}{Q_{\max }} \cdot 100 \%
$$

where: $N_{j}$ - the degree of $j^{\text {th }}$ project utility; $Q_{j}$ - the relative significance of $j^{\text {th }}$ project; $Q_{\max }$ - the most efficient relative significance from the existing projects.

Submodel for providing recommendations during project development is giving feedbacks on possible errors and mistakes, additionally, after result reviewing is giving recommendations for changing of parameters and possible result of such activity (see Fig. 3.34).

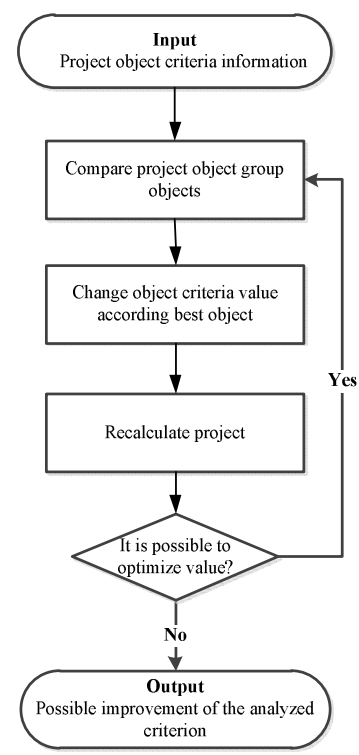

Fig. 3.34. Submodel for providing recommendations (Created by author) 
If created project has no errors, student can try to optimize specific value to make one of the alternatives more attractive. Subsystem will help to get result of possible change. For example, it is possible to try to get information on price change for specific house alternative. Model will give optimal value for price reducing, in case if price of selected alternative is not the best.

During project development Error check submodel is giving feedback on possible errors (see Fig. 3.35).

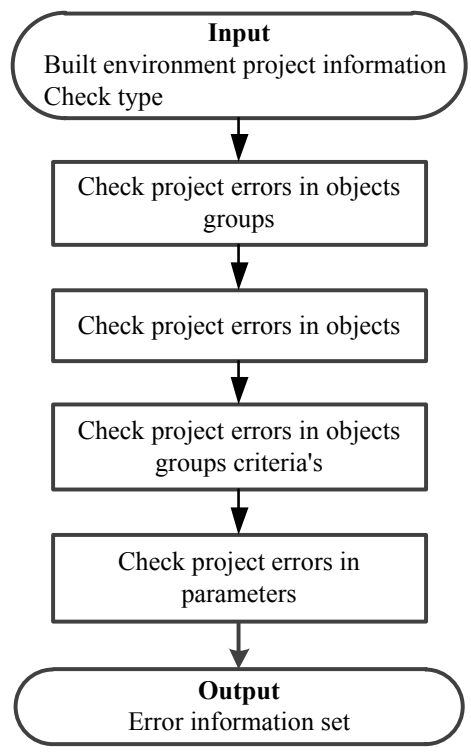

Fig. 3.35. Error check submodel (Created by author)

It is important to check all systems' object groups, objects and criteria's correctness. In case of failure subsystem will provide detail information on problematic areas. It also can help tutor to review created systems for future discussions with students.

\subsection{Conclusions for Chapter 3}

1. Model of Intelligent Tutoring System for Built Environment proposed by author was described.

2. Main parts of developed Intelligent Tutoring System for Built Environment were reviewed and described. 
3. The developed system can help students to learn reasons of wrong answers and create special learning course for missed material.

4. Model of the Intelligent Tutoring System for Built Environment was developed for the first time. It is novel due to:

- Adaptive and personalized learning and testing is performed according to the student's curiosity, preferred difficulty levels and psychological condition;

- Personalized search is available as there is a possibility to create a lot of learning alternatives and to select the best one according to individual student needs;

- The possibility to analyse, assess a lot of alternatives and select the best one while preparing homeworks, course projects and final works is ensured.

5. Personalized learning environment more precisely gives advices, chooses difficulty level and makes learning process more productive. 


\section{4}

\section{Practical Implementation of Intelligent Tutoring System for Built Environment}

In order to improve learning process of students, basing on the proposed models presented in previous chapter, Intelligent Tutoring System for Built Environment was created. The system was developed as Web application using Microsoft Visual Studio 2010 (.Net Framework 4) and C\# as a main programming language. The developed system is practically applied in study process at Vilnius Gediminas Technical University, in Construction Technology and Management as well as Real Estate Management master study programmes. During the testing of the system 340 students were registered and used the system.

Main parts of all study processes are learning and knowledge examination. In this chapter case studies from real life built environment project alternatives' development, learning process and examinations are analysed.

Full list of functions that student can use (defined in student subsystem model) is described in Fig. 4.1.

On the thematic of this chapter 8 publications (Kaklauskas et al. 2007b, 2009a, 2010a, 2012, 2013; Kanapeckiené et al. 2010; Tupénaite et al. 2010; Urbanavičienè et al. 2009) were published. 


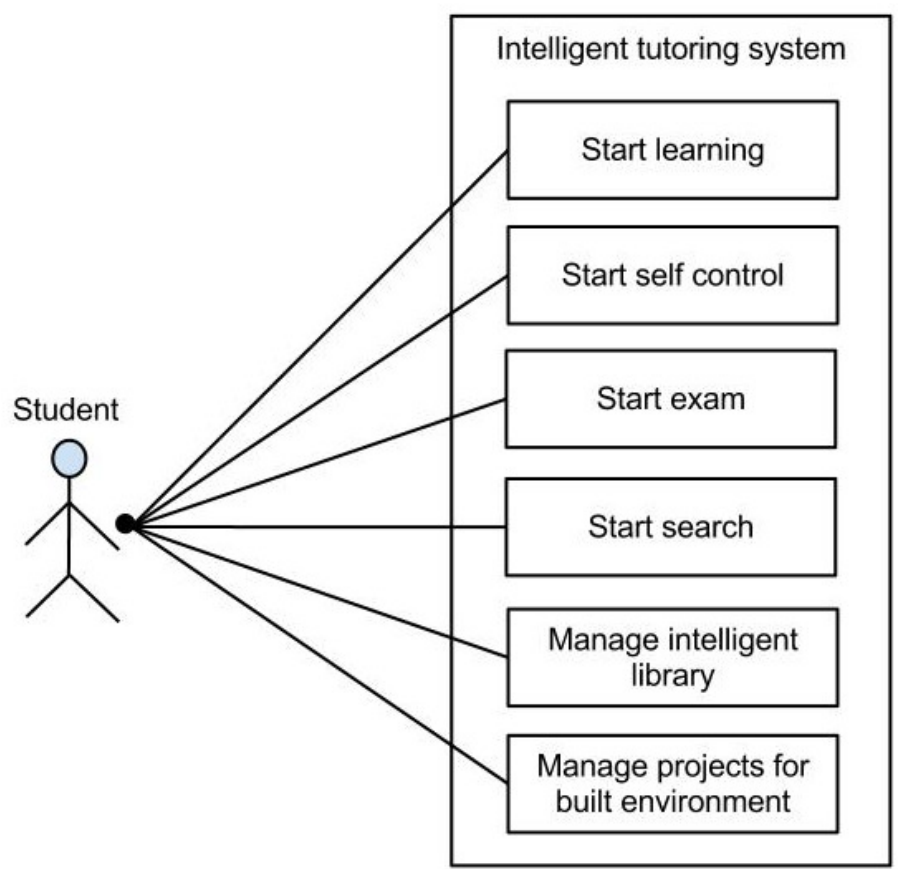

Fig. 4.1. Student and system interaction diagram (Created by author)

Three different case studies were conducted to evaluate the real effects of using Intelligent Tutoring System for Built Environment, which was developed.

Learning process of the student based on real life example is further analysed. Presented examples are based on analysis of real use of the system by students from Construction Technology and Management master study programme.

\subsection{Case Study of Students' Learning Process by Using Intelligent Library and Intelligent Search Subsystems}

Before start working with the system student has ability to study system guide. User registers to the system with unique user name and password, provided by tutor. For initial introduction to discipline material (module or its part) student chooses to read e-material (Fig. 4.2). 


\begin{tabular}{|l|l|l|l|l|l|l|l|l|l|l|l|l|l|l|l}
\hline $\begin{array}{l}\text { Your Computer Learning Systems } \\
\text { Calculators }\end{array}$ & Exams & Self control & Read & Administration & Search & My library & Personal info \\
\hline
\end{tabular}

Module

CLIMATE CHANGE: SOCIAL SCIENCE AND POLICY PERSPECTIVE

Themes of the course

1. TOTAL LIFE ANALYSIS, MODELLING AND FORECASTING OF CLIMATE CHANGE MITIGATION

2. EXPLICIT AND TACIT KNOWLEDGE

3. APPLICATION OF NEURAL NETWORKS, EXPERT AND DECISION SUPPORT SYSTEMS IN CLIMATE CHANGE

4. POLICY AND GOVERNANCE RESPONSES OF SOCIAL SYSTEMS TO CLIMATE CHANGE

5. THEORIES AND MODELS OF CLIMATE CHANGE. INTERDISCIPLINARY MODELLING

CASE STUDY

Subtopics

5.1. Political Theory and Global Climate Change

5.2. Main Theories of Climate Change

5.3. Politicization of Global Warming

5.4. Perspectives of Climate Change

5.5. Models of Climate Change

5.6. Climate Change Interaction with Economic and Social Processe

The risk of climate change depends on the physical and socioeconomic implications of a changing climate (Figure 17). Climate change might have several effects (Shogren and Toman 2000):

- Reduced productivity of natural resources that humans use or extract from the natural environment (for example, lower agricultural yields, smaller timber harvests, and scarcer water resources).

- Damage to human-built environments (for example, coastal flooding from rising sea levels, incursion of salt water into drinking water systems, and damage from increased storms and floods).

- Risks to life and limb (for example, more deaths from heat waves, storms, and contaminated water, and increased incidence of tropical diseases).

- Damage to less managed resources such as the natural conditions conducive to different landscapes, wilderness areas, natural habitats for scarce species, and biodiversity (for example, rising sea levels could inundate coastal wetlands, and increased inland aridity could destroy prairie wetlands).

Fig. 4.2. Reading of e-material (Created by author)

The study material is proposed to the student as explicit knowledge on the basis of his/her previously studied subjects and their assessment. The main difference in comparison to studies of usual paper or e-materials is that the topic or material which student already knows is not involved into the list of subject topics and subtopics or higher difficulty material is provided (higher than basic knowledge level requiring material).

User selects what he needs for future learning and saves it to his/her personal library (Fig. 4.3). By supporting student with ability to use personal library and intelligent search, system concentrates on user needs.

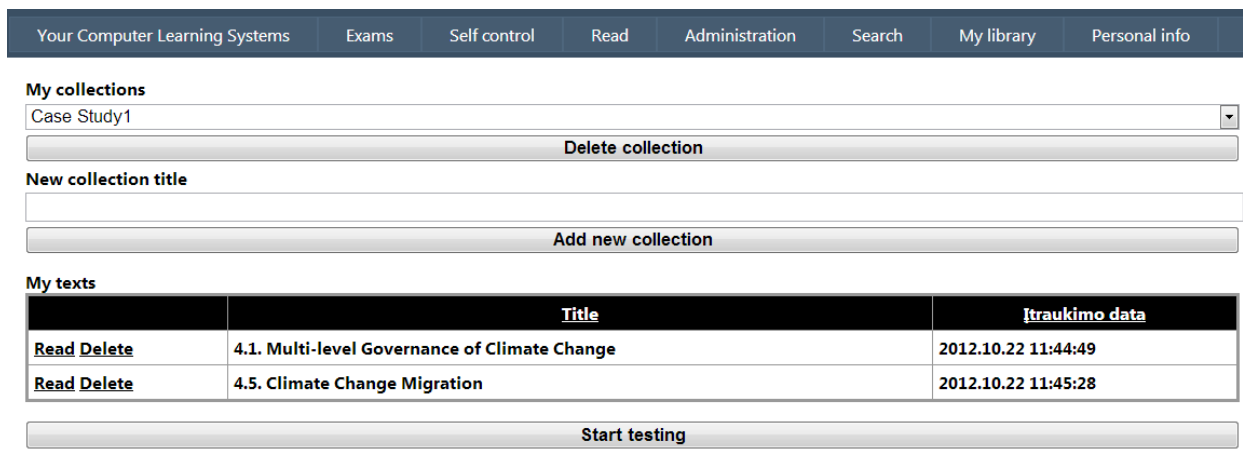

Fig. 4.3. Personal library (Created by author) 
Users in their own library collections can store 3 types of items:

- Subjects' collections from learning materials;

- Texts and subjects needed for re-examination;

- Search results.

User is able to search all database material or specific teaching material by using Intelligent Search Subsystem. Application of Intelligent Search Subsystem increases the efficiency of finding suitable study material. According to research results of Pekrun and colleagues, current intelligent tutoring systems are not providing personalized search of study material (Pekrun et al. 2007).

Fig. 4.4 shows starting window for user search.

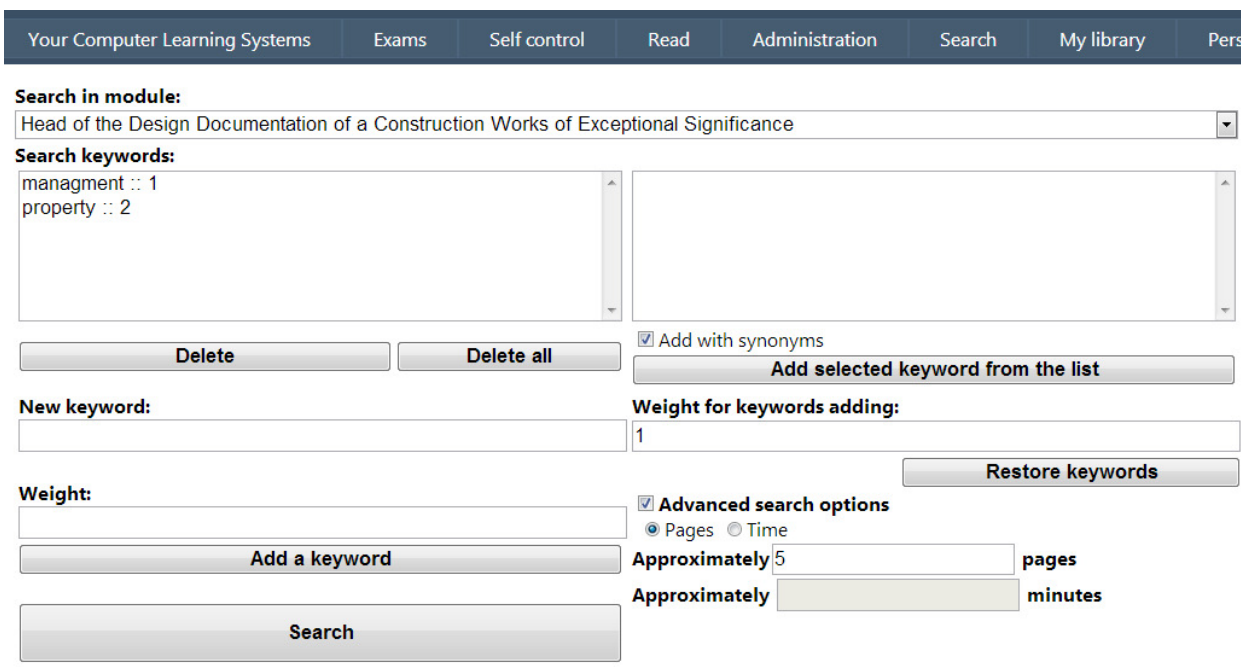

Fig. 4.4. Keywords input (Created by author)

Quick search takes one word or phrase for search. In this case advanced search with two keywords is performed. Each keyword contains additional weight information. It gives higher priority for keyword in search result. User personally is able to deal with weight scale which can be from 1 to 100 or from 0.1 to 1 . Additional feature is that keyword synonyms can be added to keywords list. There are three types of results: regular search result, search result that fits to approximately user entered pages count or reading time. In this case, the search for two keywords "management" and "property" was performed and five pages document was requested.

When "Search" button is pressed, system starts search process. First step is to reject material according to personal information. In this case learning materials with highest difficulty level and associated with passed topics are filtered. 
For further analysis 86 learning material alternatives will be used. Second step is to generate criteria set for this search (see Table 4.1).

Table 4.1. Criteria set for search of learning material

\begin{tabular}{|l|l|l|}
\hline Analysed criteria & $*$ & Weights \\
\hline Management & + & 0.3 \\
\hline Property & + & 0.2 \\
\hline $\begin{array}{l}\text { Learning material } \\
\text { difficulty }\end{array}$ & - & 0.2 \\
\hline $\begin{array}{l}\text { Learning material } \\
\text { significance }\end{array}$ & + & 0.2 \\
\hline Number of words & + & 0.05 \\
\hline Number of sentences & - & 0.02 \\
\hline Number of pages & + & 0.03 \\
\hline
\end{tabular}

* - Sign (+/-) shows, respectively, the better/poorer value of the criterion of requirements

Next step is to collect gathered learning materials' alternatives statistics and criteria parameters given by experts. After this the weighted, normalized decision-making matrix can be formed (see Table 4.2). The following formula is used for this purpose:

$$
d_{i j}=\frac{x_{i j} \cdot q_{i}}{\sum_{j=1}^{n} x_{i j}} ; i=\overline{1, m} ; j=\overline{1, n},
$$

where: $d_{i j}$ - the normalized weighted value of each criteria; $x_{i j}$ - the value of the $i^{\text {th }}$ criterion in the $j^{\text {th }}$ alternative of a learning material; $m$ - the number of criteria; $n$ - the number of the learning material alternatives compared; $q_{i}$ - weight of the $i^{\text {th }}$ criterion.

In the next step the learning material alternatives are described by minimizing indexes $S_{-j}$ and maximizing indexes $S_{+j}$ (see Table 4.3). The lower value of minimized criteria's is better and the greater value of maximized criteria's is better. The sums are calculated according to the formula:

$$
S_{+j}=\sum_{i=1}^{m} d_{+i j} ; S_{-j}=\sum_{i=1}^{m} d_{-i j} ; i=\overline{1, m} ; j=\overline{1, n} .
$$

where: $d_{-i j}$ - the normalized weighted value of minimizing criteria's; $d_{+i j}-$ the normalized weighted value of maximizing criteria's; $m$ - the number of criteria; $n-$ the number of the learning material alternatives compared. 
Table 4.2. The weighted, normalized decision-making matrix for learning materials' alternatives

\begin{tabular}{|l|l|l|l|l|l|l|}
\hline Analysed criteria & $*$ & \multirow{2}{*}{ Weights } & \multicolumn{3}{|l|}{ Analysed learning material alternatives } \\
\cline { 4 - 8 } & & & $\begin{array}{l}\text { Learning } \\
\text { material } \\
\text { alternative } 1\end{array}$ & $\begin{array}{l}\text { Learning } \\
\text { material } \\
\text { alternative } 2\end{array}$ & $\ldots$ & $\begin{array}{l}\text { Learning ma- } \\
\text { terial alternative } \\
86\end{array}$ \\
\hline Management & + & 0.3 & 0.0022 & 0.0035 & $\ldots$ & 0.0028 \\
\hline Property & + & 0.2 & 0.0011 & 0.0042 & $\ldots$ & 0.0018 \\
\hline $\begin{array}{l}\text { Learning material } \\
\text { difficulty }\end{array}$ & - & 0.2 & 0.0037 & 0.0030 & $\ldots$ & 0.0014 \\
\hline $\begin{array}{l}\text { Learning material } \\
\text { significance }\end{array}$ & + & 0.2 & 0.0045 & 0.0018 & $\ldots$ & 0.0066 \\
\hline Number of words & + & 0.05 & 0.0024 & 0.0070 & $\ldots$ & 0.0087 \\
\hline Number of sentences & - & 0.02 & 0.0030 & 0.0041 & $\ldots$ & 0.0034 \\
\hline Number of pages & + & 0.03 & 0.0006 & 0.0006 & $\ldots$ & 0.0007 \\
\hline
\end{tabular}

* Sign (+/-) shows, respectively, the better/poorer value of the criterion of requirements

Table 4.3. The weighted, normalized decision-making matrix with sums of maximizing and minimizing normalized weighted values for learning materials' alternatives

\begin{tabular}{|c|c|c|c|c|c|c|}
\hline \multirow[t]{2}{*}{ Analysed criteria } & \multirow[t]{2}{*}{$*$} & \multirow[t]{2}{*}{ Weights } & \multicolumn{4}{|c|}{ Analysed learning material alternatives } \\
\hline & & & $\begin{array}{l}\text { Learning material } \\
\text { alternative } 1\end{array}$ & $\begin{array}{l}\text { Learning ma- } \\
\text { terial alternative } \\
2\end{array}$ & $\ldots$ & $\begin{array}{l}\text { Learning ma- } \\
\text { terial alternative } \\
86\end{array}$ \\
\hline Management & + & 0.3 & 0.0022 & 0.0035 & $\cdots$ & 0.0028 \\
\hline Property & + & 0.2 & 0.0011 & 0.0042 & $\cdots$ & 0.0018 \\
\hline $\begin{array}{l}\text { Learning material } \\
\text { difficulty }\end{array}$ & - & 0.2 & 0.0037 & 0.0030 & $\cdots$ & 0.0014 \\
\hline $\begin{array}{l}\text { Learning material } \\
\text { significance }\end{array}$ & + & 0.2 & 0.0045 & 0.0018 & $\cdots$ & 0.0066 \\
\hline Number of words & + & 0.05 & 0.0024 & 0.0070 & $\cdots$ & 0.0087 \\
\hline Number of sentences & - & 0.02 & 0.0030 & 0.0041 & $\cdots$ & 0.0034 \\
\hline Number of pages & + & 0.03 & 0.0006 & 0.0006 & $\cdots$ & 0.0007 \\
\hline \multicolumn{3}{|c|}{$\begin{array}{l}\text { Sum of maximizing normalized } \\
\text { weighted values }\left(S_{+}\right)\end{array}$} & 0.0108 & 0.0171 & $\cdots$ & 0.0206 \\
\hline \multicolumn{3}{|c|}{$\begin{array}{l}\text { Sum of minimizing normalized } \\
\text { weighted values }\left(S_{-}\right)\end{array}$} & 0.0067 & 0.0071 & $\cdots$ & 0.0048 \\
\hline
\end{tabular}

* - Sign (+/-) shows, respectively, the better/poorer value of the criterion of requirements 
The significance of the compared learning material alternative is determined by describing the characteristics of positive learning material alternatives ("pluses") and negative learning material alternatives ("minuses"). The relative significance $Q_{j}$ of each learning material alternative is found according to the formula:

$$
Q_{j}=S_{+j}+\frac{S_{-\min } \cdot \sum_{j=1}^{n} S_{-j}}{S_{-j} \cdot \sum_{j=1}^{n} \frac{S_{-\min }}{S_{-j}}} ; j=\overline{1, n} .
$$

where: $\mathrm{Q}_{j}$ - significance of the compared learning material alternative; $\mathrm{S}_{+j}$ - the sum of maximizing normalized weighted values; $S_{-j}-$ the sum of minimizing normalized weighted values; $S_{-\min }$ - the minimal $S_{-j}$ value of all learning material alternatives; $n$ - the number of the learning material alternatives compared.

Table 4.4. The weighted, normalized decision-making matrix with the determined priorities for learning materials' alternatives

\begin{tabular}{|l|l|l|l|l|l|l|}
\hline Analysed criteria & $*$ & Weights & \multicolumn{4}{|l|}{ Analysed learning material alternatives } \\
\cline { 3 - 7 } & & & $\begin{array}{l}\text { Learning material } \\
\text { alternative 1 }\end{array}$ & $\begin{array}{l}\text { Learning material } \\
\text { alternative 2 }\end{array}$ & $\ldots$ & $\begin{array}{l}\text { Learning } \\
\text { material alter- } \\
\text { native } 86\end{array}$ \\
\hline Management & + & 0.3 & 0.0022 & 0.0035 & $\ldots$ & 0.0028 \\
\hline Property & + & 0.2 & 0.0011 & 0.0042 & $\cdots$ & 0.0018 \\
\hline $\begin{array}{l}\text { Learning material } \\
\text { difficulty }\end{array}$ & - & 0.2 & 0.0037 & 0.0030 & $\cdots$ & 0.0014 \\
\hline $\begin{array}{l}\text { Learning material } \\
\text { significance }\end{array}$ & + & 0.2 & 0.0045 & 0.0018 & $\cdots$ & 0.0066 \\
\hline Number of words & + & 0.05 & 0.0024 & 0.0070 & $\cdots$ & 0.0087 \\
\hline Number of sentences & - & 0.02 & 0.0030 & 0.0041 & $\cdots$ & 0.0034 \\
\hline Number of pages & + & 0.03 & 0.0006 & 0.0006 & $\cdots$ & 0.0007 \\
\hline $\begin{array}{l}\text { Sum of maximizing normalized } \\
\text { weighted values }\left(S_{+}\right)\end{array}$ & 0.0108 & 0.0171 & $\cdots$ & 0.0206 \\
\hline $\begin{array}{l}\text { Sum of minimizing normalized } \\
\text { weighted values }\left(S_{-}\right)\end{array}$ & 0.0067 & 0.0071 & $\cdots$ & 0.0048 \\
\hline $\begin{array}{l}\text { The significance of the learning } \\
\text { material alternative }\end{array}$ & 0.1925 & 0.2609 & $\cdots$ & 0.2406 \\
\hline $\begin{array}{l}\text { The priorities of the learning materi- } \\
\text { al alternatives }\end{array}$ & 17 & 3 & $\cdots$ & 5 \\
\hline
\end{tabular}

* - Sign (+/-) shows, respectively, the better/poorer value of the criterion of requirements 
The priorities of the learning materials' alternatives are determined by comparing the significances of the learning materials' alternatives. The greater is the $Q_{j}$ the higher is the priority (see Table 4.4 ).

When the priorities of the learning materials alternatives are calculated, system can start creating requested 5 pages document. Using priority information from the top of learning material ordered list, document will be formed taking one by one alternative. Process will be stopped after at least 5 page document created.

Search result is presented in Fig. 4.5.

CREATED DOCUMENT WORDS COUNT:11136

111. HINKS, J. FM in the future - a speculation on key performance issues. In Proceedings of the International Conference on Futures in Property and FM: Creating the Platform for Innovation. University College, London. 1999.

...Read

2 Lietuvoje ir Estijoje nuomos rinkos kainos augo kur kas lečiau negu pirkimo ir pardavimo kainos. Pavyzdžiui, Taline 2003$2007 \mathrm{~m}$. vidutinè nuomos kaina už 2 kambarių butą išaugo $34 \%$, o pardavimo kaina - $179 \%$, trijų kambarių butų nuomos kaina išaugo 10,6 \%, o pardavimo kaina $203 \%$ (Global Property Guide 2008, http://www.globalpropertyguide.com/). ...Read 3 Rusijos Federacija Facilities Management supranta kaip Управление недвижимостью (nekilnojamojo turto valdymas), tuo pagrịsdama platesnio valdymo objektų spektro galimybę. ...Read

4 Sąvoka Facilities Management atsirado JAV XX a. viduryje. Žodis Facilities ịvardija žemės sklypus, pastatus, j̇renginius, prietaisus, technines pagalbines priemones ir infrastruktürą [9]. .... Read

5 Pastatų ūkio valdymo plètros kelias Europoje lètas ir sudètingas. Ši sąvoka pirmą kartą buvo pavartota $1980 \mathrm{~m}$. Anglijoje architekto Francis Duffi. Čia $1985 \mathrm{~m}$. buvo jkurta AFM - Association of Facility Managers and Institute of Administrative Management / Facilites Management Group (IFM / FMG) [21] ....Read

6 Pasirinktos antiinfliacinės priemonės turèjo ịtakos Latvijos nekilnojamojo turto rinkos dinamikai, todėl buvo pasiektas pagrindinis tikslas: sumažejo spekuliacinių sandorių skaičius, paklausa, investicijos nukreiptos j̣ kitas kryptis, bankai tapo atsargesni išduodami paskolas, o teisinis skolinimosi ir taupymo reguliavimas sugriežtintas. Tai buvo pagrindinè priemonė, turejusi įtakos staigiam kainų kritimui, tačiau veikẻ ir kiti veiksniai - didejantis skirtumas tarp gyventojų pajamų ir nekilnojamojo turto kainų, kainų kritimo lūkesčiai, palūkanų normos augimas, spartejantys infliacijos tempai, griežtesnè banku skolinimo politika, nekilnojamojo turto rinkos nepatikimumas, nestabili šalies ekonominė padètis (Global Property Guide 2008, http://www.globalpropertyguide.com/)....Read

7 Iš tarptautinès PŪV asociacijos (International Facility Management Association, IFMA) pateikto apibrèžimo [12] matyti, kad pagrindinè PŪV veikla yra neatskiriamai susijusi su organizacijos nekilnojamojo turto (NT) priežiüra ir valdymu, su paramos teikimu kaip produktyvia darbo aplinka: „PŪV $\square$ tai atskira valdymo funkcija, kuri apima tam tikrą apibrèžtą atsakomybių kompleksą“. Paprasčiau sakant, turto valdymas $\square$ organizacijos priemonių valdymas. ...Read 8 Nekilnojamojo turto projekto valdymo tikslas yra užtikrinti, kad vystytojo poreikiai būtų patenkinti, pvz., sudarant projekto koaliciją, valdant biudžetą ir išlaikant pusiausvyrą tarp projekto laiko, išlaidų, kokybès ir apimties, valdant sutartinius santykius, derinant techninius reikalavimus ir planus bei požiūrị ị problemas ir ịvairių suinteresuotujų grupių lūkesčius (Kerzner, 2010; PMI, 2008; Walker, 2007; Winch, 2010). Yra daug priemonių, skirtų nekilnojamojo turto projektams planuoti, grafikams sudaryti, monitoringui ir projekto veiklos ataskaitoms parengti. Projektų vadovai pasiekti projekto tikslus padeda tinkamų priemonių ir technologijų, pvz., darbo išskaidymo struktūros (angl. Work Breakdown Structure (WBS)), kritinis kelio metodo (angl. Critical Path Method (CPM)) ir igytosios vertes valdymo (angl. Earned Value Management (EVM)), naudojimas. ....Read

9 Projektų valdymo problemas nagrinejja Tarptautiné projektų valdymo asociacija ir Projektų valdymo institutas. Šiems klausimams skirtas tarptautinis žurnalas „International Journal of Project Management“ (žr.

http://www.sciencedirect.com/science/journal/02637863). Parengtas standartas ISO 10006: 2003(E) „Quality management systems - guidelines for quality management in projects" (http://www.iso.org/iso/catalogue_detail.htm? csnumber=36643) ir kiti standartai. ....Read

10 Aukštos kokybės standartine pastato fasado ir bendrų naudojimo patalpų apdaila, šiuolaikiškos pastato inžinerinės sistemos, prioritetas pastato valdymo sistemai (BMS - Building Management System) - tai sistema leidžianti realiu laiku valdyti inžinerines pastato sistemas, stebėti ir automatiškai archyvuoti būtiniausią informaciją, siųsti pranešimus apie pastatuose esamų sistemų veikimo pokyčius ir energetinių išteklių naudojimą; ...Read

Fig. 4.5. Search result (Created by author) 
Text of each result gives link to full document for additional studies or information for storage in own library. The whole search result also can be stored in new personal library collection or added to existing one.

For students who are requesting more additional materials, system provides links to video lectures or online calculations provided by other universities according to the chosen subject (Fig. 4.6).

\begin{tabular}{|c|c|c|c|c|c|c|c|c|c|}
\hline Your C & Exams & Self control & Read & Administration & Search & My library & Personal info & Calculators & Video \\
\hline
\end{tabular}

TOP 20 Universities Videos to Climate Change

1. Yale University, Prof. John Wargo: Lecture 20 - Managing Coastal Resources in an Era of Climate Change http://videolectures.net/yaler

2. University of Cambridge, D. A. Hodell: Abrupt Climate Change During the Last Ice Age From the Perspective of $17^{\circ} \mathrm{N}, 90^{\circ} \mathrm{W}$ http://wwn

3. University of Cambridge, Alison Cooke talks to Climate Change TV about the global energy demands http://www.youtube.com/watch?

4. Imperial Colledge London, Sir Brian Hoskins: What does the future hold? http://www.youtube.com/watch?v=Avl1kPL1w5M

5. Stanford University, Andreas Schafer: Transportation and Climate Change http://www.youtube.com/watch?v=8gXUDVrwfcQ

6. University of Cambridge, Professor David MacKay FRS: How the Laws of Physics Constrain Our Sustainable Energy Options http://www

I. University of Cambridge, Professor Sir Partha Sarathi Uasgupta, rBA, rKS: Climate Protection May Cost Less I han You Ihink http://ww

8. University of Cambridge, Professor David MacKay FRS: Sustainable Energy - Without the Hot Air http://www.youtube.com/watch?v=G

9. Stanford University, Professor Mark Z. Jacobson, Stewart Brand Debate: Does the world need nuclear energy? http://www.youtube.con

10. University of Cambridge, Terry Barker: Decarbonisation and the Credit Crisis http://www.youtube.com/watch?v=HQps1FyaTns

11. University of Cambridge, Martin Sewell: BITCI CEO Forum on Climate Change 2009

a. Part 1 http://www.youtube.com/watch?v=wUjpWxdTVus\&feature=relmfu

b. Part 2 http://www.youtube.com/watch?v=fSImWl59MmM\&feature=relmfu

c. Part 3 http://www.youtube.com/watch?v=QiUL476Wa1o\&feature=relmfu

12. University of Cambridge, Gloria Chang: Sea ice melt is like our global air conditioner breaking down http://www.youtube.com/watch?v=

13. Yale University, Nayan Chanda and Bo Ekman: Is Global Warming Real? How To Avert the Threat http://www.youtube.com/watch?v=PII

14. Yale University, Anthony Leiserowitz, Ph.D.: Global Warming's Six Americas http://www.youtube.com/watch?v=2I5u9rfUSLA

Fig. 4.6. Links to video lectures of Top 20 Universities (Created by author)

Scientists Gutierrez and Atkinson and others during their research found that it is very important to guarantee the appropriate feedback between the participants of study process (Gutierrez and Atkinson 2011; Urban-Lurain 2010).

The presented Intelligent Tutoring System, performs this function in the automated way (by providing assessment and links for additional studies). User has no limitations in creating the collection. Additionally he has ability to take collection tests and check knowledge level in one or another field. 


\subsection{Case Study of Students' Self-Tests and Examination Process by Using Intelligent Tutoring Subsystem}

The main part of tutoring process is to collect primary information about the student. That information will help to determine starting difficulty of tutoring and material, self-tests and examination that need to be filtered. User can add additional data by managing his/her account. Fig. 4.7 shows administration window of user's personal information.

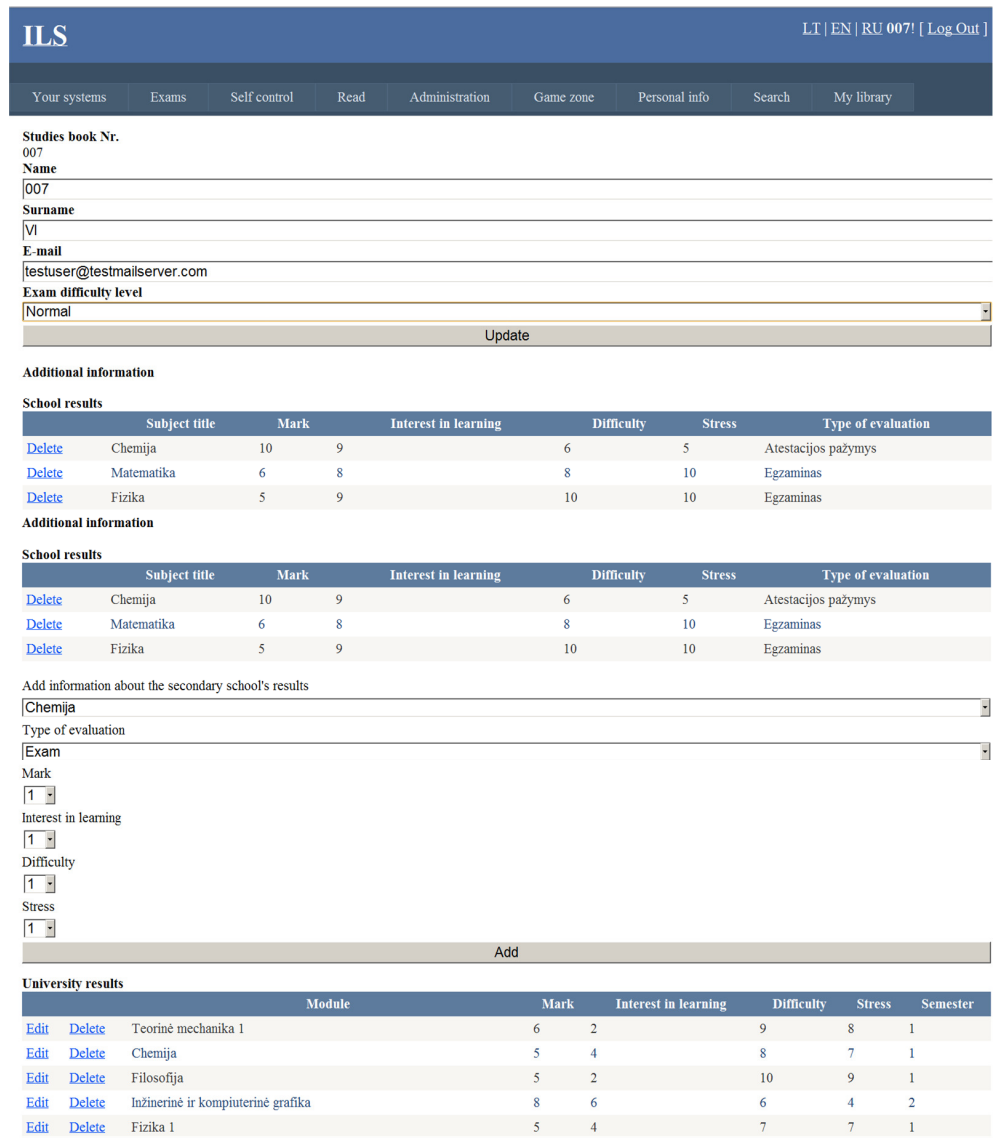

Fig. 4.7. Personal information (Created by author)

User is also able to manually choose starting complexity level of test (Fig. 4.8). 


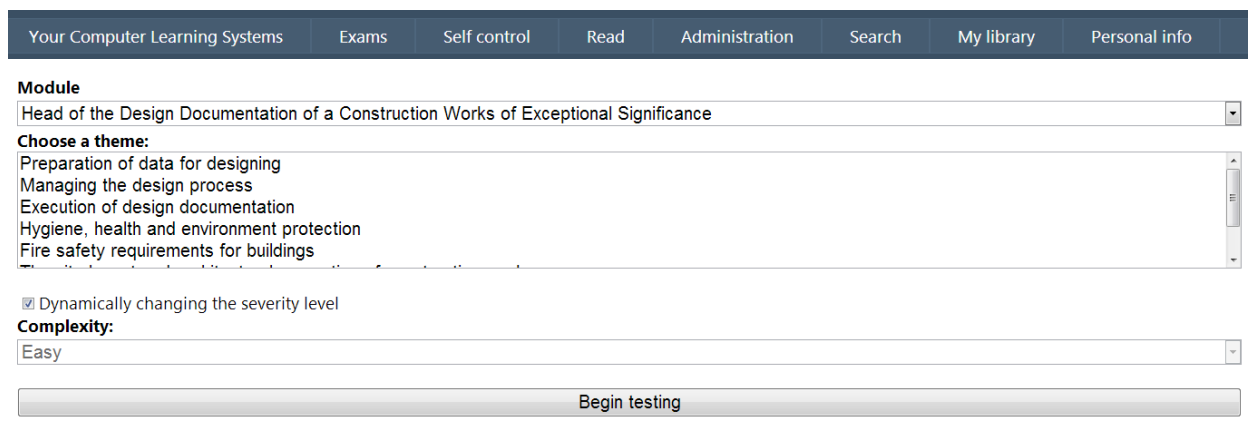

Fig. 4.8. Manual and dynamic choosing of test complexity level

When "Begin testing" button is pressed, system is collecting questions associated with the selected topic. During this process already successfully passed questions are filtered. Additionally personal student filter rejects not desirable at that moment, according personal student selected parameters, questions. For further analysis 24 questions alternatives for self-test will be used. For test questions' alternatives analysis set of criteria is generated (see Table 4.1).

Table 4.5. Set of criteria for test questions' alternatives

\begin{tabular}{|l|l|l|}
\hline Analysed criteria & $*$ & Weights \\
\hline Question difficulty & - & 0.35 \\
\hline Question significance & + & 0.35 \\
\hline $\begin{array}{l}\text { Recommended maximal } \\
\text { stress level }\end{array}$ & - & 0.15 \\
\hline $\begin{array}{l}\text { Recommended minimal } \\
\text { curiosity level }\end{array}$ & - & 0.15 \\
\hline
\end{tabular}

* - Sign (+/-) shows, respectively, the better/poorer value of the criterion of requirements

Next step is to collect gathered criteria parameters of test questions' alternatives given by experts. After this the weighted, normalized decision-making matrix can be formed (see Table 4.2). The following formula is used for this purpose:

$$
d_{i j}=\frac{x_{i j} \cdot q_{i}}{\sum_{j=1}^{n} x_{i j}} ; i=\overline{1, m} ; j=\overline{1, n},
$$

where: $d_{i j}$ - the normalized weighted value of each criteria; $x_{i j}$ - the value of the $i^{\text {th }}$ criterion in the $j^{\text {th }}$ alternative of a test question; $m$ - the number of criteria; $n-$ 
the number of the test question alternatives compared; $q_{i}$ - weight of the $i^{\text {th }}$ criterion.

Table 4.6. The weighted, normalized decision-making matrix for test questions' alternatives

\begin{tabular}{|l|l|l|l|l|l|l|}
\hline Analysed criteria & $*$ & Weights & \multicolumn{4}{|l|}{ Analysed test question alternatives } \\
\cline { 3 - 7 } & & $\begin{array}{l}\text { Test question } \\
\text { alternative 1 }\end{array}$ & $\begin{array}{l}\text { Test question } \\
\text { alternative 2 }\end{array}$ & $\ldots$ & $\begin{array}{l}\text { Test question } \\
\text { alternative 24 }\end{array}$ \\
\hline Question difficulty & - & 0.35 & 0.0206 & 0.0137 & $\ldots$ & 0.0206 \\
\hline $\begin{array}{l}\text { Question signific- } \\
\text { ance }\end{array}$ & + & 0.35 & 0.0107 & 0.008 & $\ldots$ & 0.0214 \\
\hline $\begin{array}{l}\text { Recommended max- } \\
\text { imal stress level }\end{array}$ & - & 0.15 & 0.0063 & 0.0071 & $\ldots$ & 0.0063 \\
\hline $\begin{array}{l}\text { Recommended mi- } \\
\text { nimal curiosity } \\
\text { level }\end{array}$ & - & 0.15 & 0.008 & 0.0057 & $\ldots$ & 0.0102 \\
\hline
\end{tabular}

* - Sign (+/-) shows, respectively, the better/poorer value of the criterion of requirements

In the next step the test questions alternatives are described by minimizing indexes $S_{-j}$ and maximizing indexes $S_{+j}$ (see Table 4.7).

Table 4.7. The weighted, normalized decision-making matrix with sums of maximizing and minimizing normalized weighted values for test questions' alternatives

\begin{tabular}{|l|l|l|l|l|l|l|}
\hline Analysed criteria & $*$ & Weights & \multicolumn{3}{|l|}{ Analysed test question alternatives } \\
\cline { 3 - 7 } & & $\begin{array}{l}\text { Test question } \\
\text { alternative 1 }\end{array}$ & $\begin{array}{l}\text { Test question } \\
\text { alternative 2 }\end{array}$ & $\ldots$ & $\begin{array}{l}\text { Test question } \\
\text { alternative 24 }\end{array}$ \\
\hline Question difficulty & - & 0.35 & 0.0206 & 0.0137 & $\ldots$ & 0.0206 \\
\hline $\begin{array}{l}\text { Question signific- } \\
\text { ance }\end{array}$ & + & 0.35 & 0.0107 & 0.008 & $\ldots$ & 0.0214 \\
\hline $\begin{array}{l}\text { Recommended max- } \\
\text { imal stress level }\end{array}$ & - & 0.15 & 0.0063 & 0.0071 & $\ldots$ & 0.0063 \\
\hline $\begin{array}{l}\text { Recommended } \\
\text { minimal curiosity } \\
\text { level }\end{array}$ & - & 0.15 & 0.008 & 0.0057 & $\ldots$ & 0.0102 \\
\hline $\begin{array}{l}\text { Sum of maximizing normalized } \\
\text { weighted values }\left(S_{+}\right)\end{array}$ & 0.0107 & 0.008 & $\ldots$ & 0.0214 \\
\hline $\begin{array}{l}\text { Sum of minimizing normalized } \\
\text { weighted values }\left(S_{-}\right)\end{array}$ & 0.0349 & 0.0265 & $\ldots$ & 0.0371 \\
\hline
\end{tabular}

* - Sign (+/-) shows, respectively, the better/poorer value of the criterion of requirements 
The lower value of minimized criteria's is better and the greater value of maximized criteria's is better. The sums are calculated according to the formula:

$$
S_{+j}=\sum_{i=1}^{m} d_{+i j} ; S_{-j}=\sum_{i=1}^{m} d_{-i j} ; i=\overline{1, m} ; j=\overline{1, n} .
$$

where: $d_{-i j}$ - the normalized weighted value of minimizing criteria's; $d_{+i j}-$ the normalized weighted value of maximizing criteria's; $m$ - the number of criteria; $n-$ the number of the test question alternatives compared.

Table 4.8. The weighted, normalized decision-making matrix with the determined priorities for test questions' alternatives

\begin{tabular}{|l|l|l|l|l|l|l|}
\hline Analysed criteria & $*$ & Weights & \multicolumn{4}{|l|}{ Analysed test question alternatives } \\
\cline { 3 - 7 } & & & $\begin{array}{l}\text { Test question } \\
\text { alternative 1 }\end{array}$ & $\begin{array}{l}\text { Test question } \\
\text { alternative 2 }\end{array}$ & $\ldots$ & $\begin{array}{l}\text { Test question } \\
\text { alternative 24 }\end{array}$ \\
\hline Question difficulty & - & 0.35 & 0.0206 & 0.0137 & $\ldots$ & 0.0206 \\
\hline Question significance & + & 0.35 & 0.0107 & 0.008 & $\ldots$ & 0.0214 \\
\hline $\begin{array}{l}\text { Recommended maximal } \\
\text { stress level }\end{array}$ & - & 0.15 & 0.0063 & 0.0071 & $\cdots$ & 0.0063 \\
\hline $\begin{array}{l}\text { Recommended minimal } \\
\text { curiosity level }\end{array}$ & - & 0.15 & 0.008 & 0.0057 & $\cdots$ & 0.0102 \\
\hline $\begin{array}{l}\text { Sum of maximizing normalized weighted } \\
\text { values }\left(S_{+}\right)\end{array}$ & 0.0107 & 0.008 & $\cdots$ & 0.0214 \\
\hline $\begin{array}{l}\text { Sum of minimizing normalized weighted } \\
\text { values }\left(S_{-}\right)\end{array}$ & 0.0349 & 0.0265 & $\cdots$ & 0.0371 \\
\hline $\begin{array}{l}\text { The significance of the test question alter- } \\
\text { natives }\end{array}$ & 0.0302 & 0.0337 & $\cdots$ & 0.0398 \\
\hline $\begin{array}{l}\text { The priorities of the test question alterna- } \\
\text { tives }\end{array}$ & 24 & 22 & $\cdots$ & 13 \\
\hline
\end{tabular}

* - Sign (+/-) shows, respectively, the better/poorer value of the criterion of requirements

The significance of the compared test question alternative is determined by describing the characteristics of positive test question alternatives ("pluses") and negative test question alternatives ("minuses"). The relative significance $Q_{j}$ of each test question alternative is found according to the formula:

$$
Q_{j}=S_{+j}+\frac{S_{-\min } \cdot \sum_{j=1}^{n} S_{-j}}{S_{-j} \cdot \sum_{j=1}^{n} \frac{S_{-\min }}{S_{-j}}} ; j=\overline{1, n} .
$$


where: $\mathrm{Q}_{j}$ - significance of the compared test question alternative; $\mathrm{S}_{+j}-$ the sum of maximizing normalized weighted values; $\mathrm{S}_{-j}$ - the sum of minimizing normalized weighted values; $S_{-\min }$ - the minimal $S_{-j}$ value of all test question alternatives; $n$ - the number of the test question alternatives compared.

The priorities of the test question alternatives are determined by comparing the significances of the test question alternatives. The greater is the $Q_{j}$ the higher is the priority (see Table 4.8).

When the priorities of the test questions' alternatives are calculated, top 20 questions are taken for testing needs. During the test they appear in random sequence and in case of big amount of fails, left amount of questions can be regenerated by lowering the difficulty level. For example, Fig. 4.9 illustrates that Intelligent Tutoring Subsystem has changed difficulty level from "level 1" to "level 2" during the test.

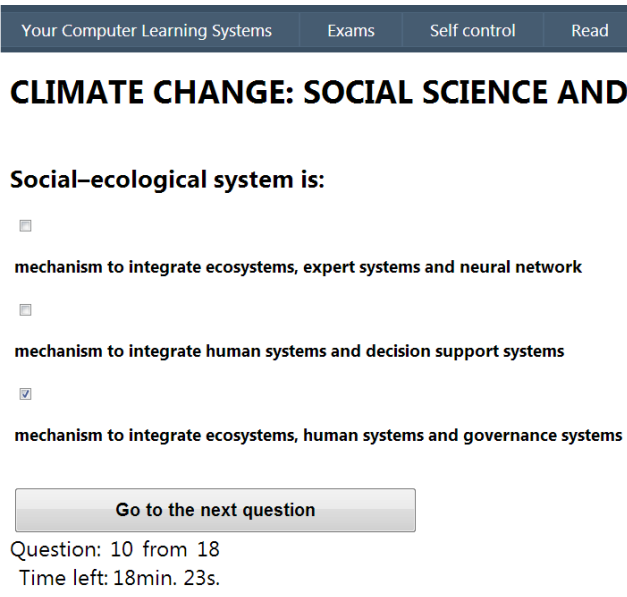

Fig. 4.9. Self-test. Randomly listed questions and answers and dynamically assigned difficulty (Created by author)

In the analysed case it actually happened - at the beginning of the self-test student received questions with difficulty level " 2 ". Though he failed to answer one to another number of questions established by test administrator, the system automatically modified further questions to simpler ones - from difficulty level "1". When test is finished, user gets mark with wrong answers' explanations (Fig. 4.10).

Test administrator is able to manage count of correct or incorrect answers in order to raise or lower difficulty; additionally, test can be ended after few answers. Basing on wrong answers teaching material is prepared. User can save it (in "collections") for future studies (Fig. 4.11). 


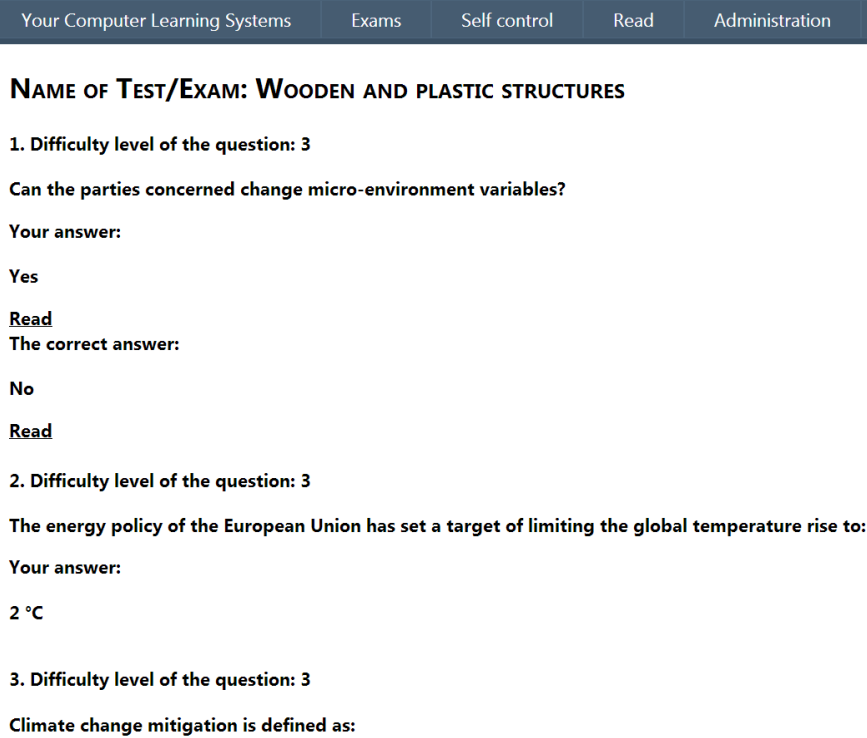

Fig. 4.10. Results of self-test (Created by author)

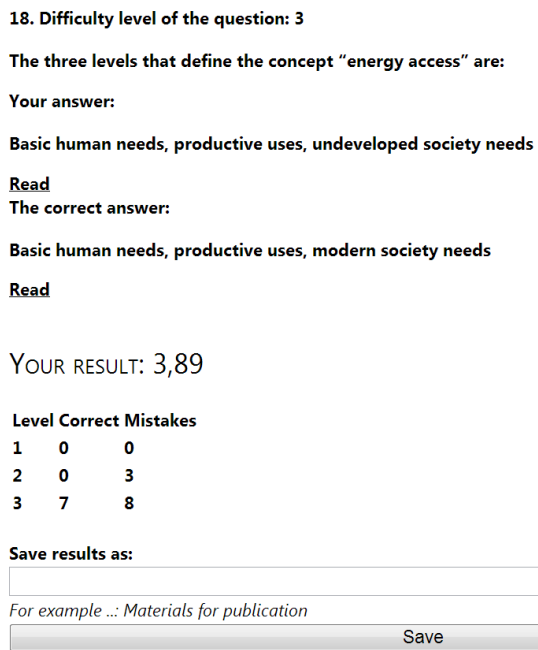

Fig. 4.11. Storing of not learned (failure answering of self tests questions) material to personal library (Created by author)

Student stores to his/her personal library all the material connected to wrongly answered questions during the self-test. After the second study of material, student takes self-test again and re-examines his knowledge (Fig. 4.12). 


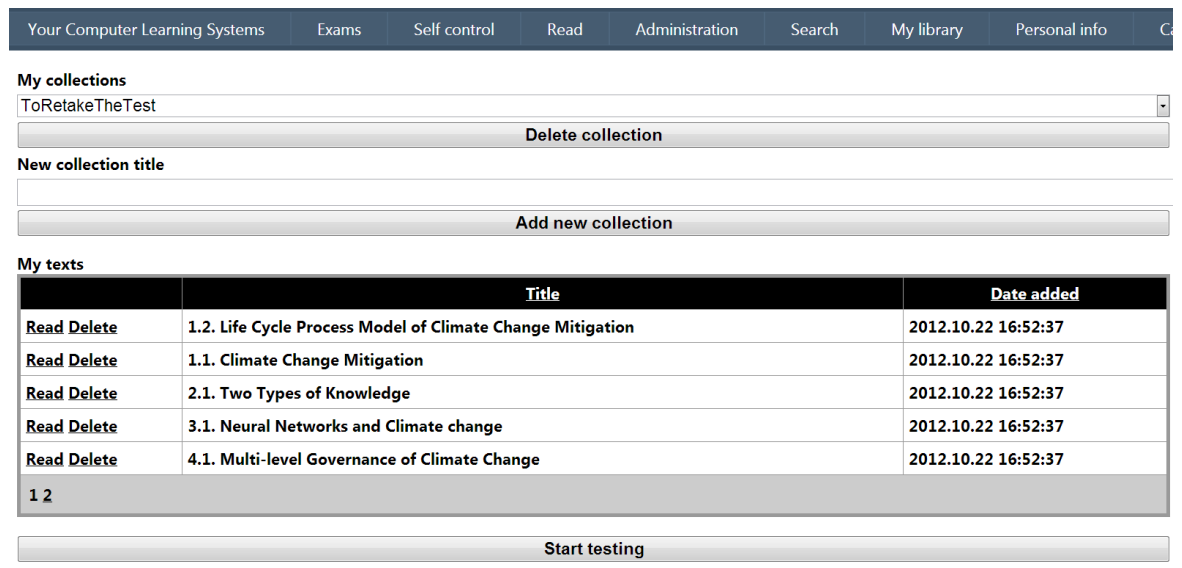

Fig. 4.12. Re-examination of knowledge from the study material stored in student's personal library (Created by author)

Study and self-testing process repeats till the moment that student provides right answers to all of the questions.

Self-test date, assessment (mark), information on right and wrong answered questions of each student are stored in Historical Statistics Database. Student and tutor (administrator of the system) is able to review this data (Fig. 4.13).

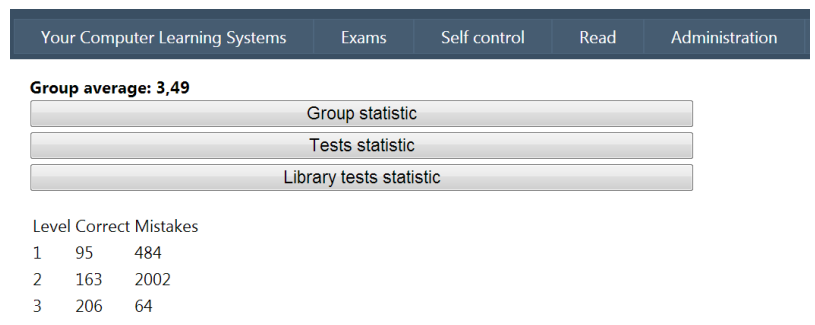

Fig. 4.13. View of historical statistics database (Created by author)

One of the factors influencing self-motivation is competition. Student who is getting statistical information about achievements of students from his/her group is concerned to keep up with and even to outmatch. Student is provided with information about:

- Average results of particular test and exam;

- The most difficult questions rated by system;

- Taken tests from collections stored in "My library".

Tutor is able to change the parameters of student's individual study programme (i.e. difficulty level) or to give advices directly to the student. 
The importance to individualized tutoring was proven by Lentidis and Haltsis. In the developed Intelligent Tutoring System it is implemented on the basis of study material and self-testing. Dynamic provision of learning material and difficulty, determination of student's character features helps to choose the most appropriate learning style which importance has been proven in scientific works (Popescu 2010).

\subsection{Case Study of Evaluation of Built Environment Projects' Alternatives}

Basing on the previously discussed methods, the Built Environment Computer Learning Subsystem (BECLS) was developed. Every user of the system has ability to create new project or import existing best practice projects for future modifications (see Fig. 4.14).

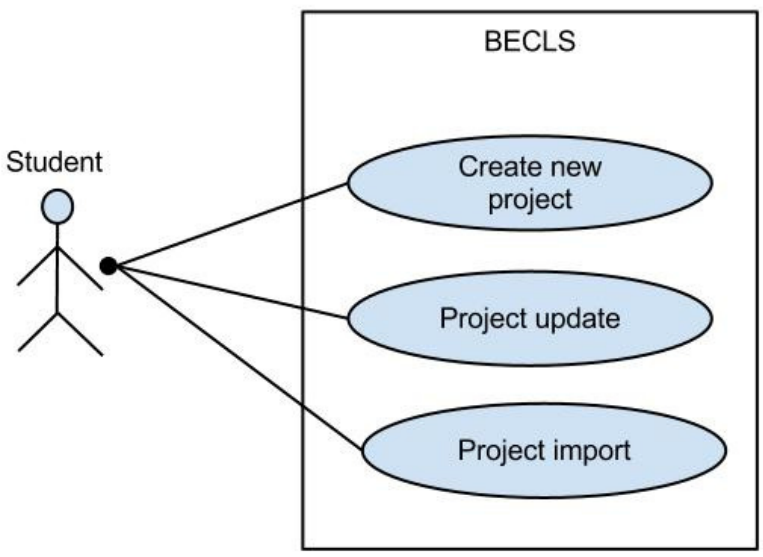

Fig. 4.14. Actions of built environment computer learning subsystem user (Created by author)

There is no limitation for projects' count or size of BECLS user. BECLS subsystem performs integrated checking of projects and user cannot publish created project if it did not pass the check. The result of project check is errors list that can show problematic areas and solutions for corrections of errors.

The administrator of BECLS subsystem additionally is able to create new best practice templates for the BECLS subsystem templates library. Administrator can make changes and corrections in all projects created in BECLS subsystem (Fig. 4.15). 


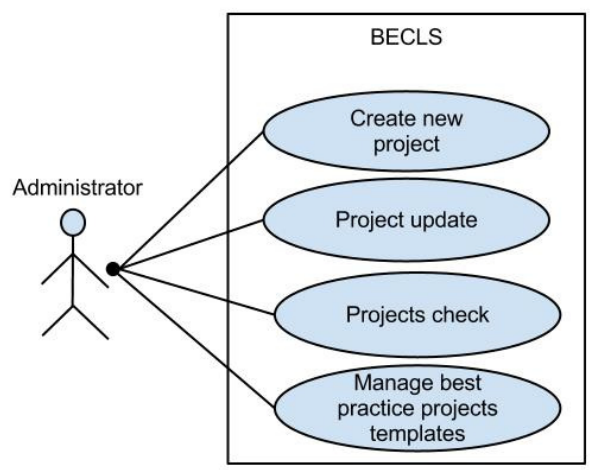

Fig. 4.15. Actions of built environment computer learning subsystem administrator (Created by author)

Project design scheme in the BECLS is illustrated in Fig. 4.16.

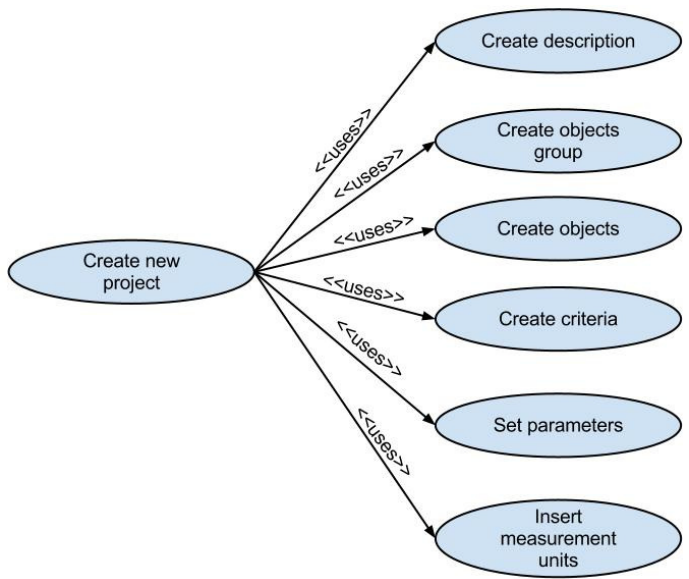

Fig. 4.16. Creating of new built environment computer learning subsystem project (Created by author)

Correct objects and criteria's are important as well as correct and understandable descriptions are needed in order to make personal BECLS project user friendly. Only measurement units can be reused in all systems of user. Each user creates his own collection of measurement units, and only in case of importing best practice data measurement units are added automatically.

Creating of the new project in BECLS starts with development of system description, it can be updated in future. Next step can be creating of objects' 
group or inserting measurement units. When needed objects' groups and measurement units are obtained, criteria of objects and objects' groups can be developed.

At the end it is possible to set parameters for objects' parameters. If system passes errors check it can be published for public use or can be used for personal purposes.

In order to show the real life application of the BECLS subsystem, project "Analysis of 6 main building requirements" created by one of system users will be taken as an example.

First step is to create project name and description. By web text editor user is able to add additionally some documents, video material and useful links. In this example it is just system name and short description (Fig. 4.17).

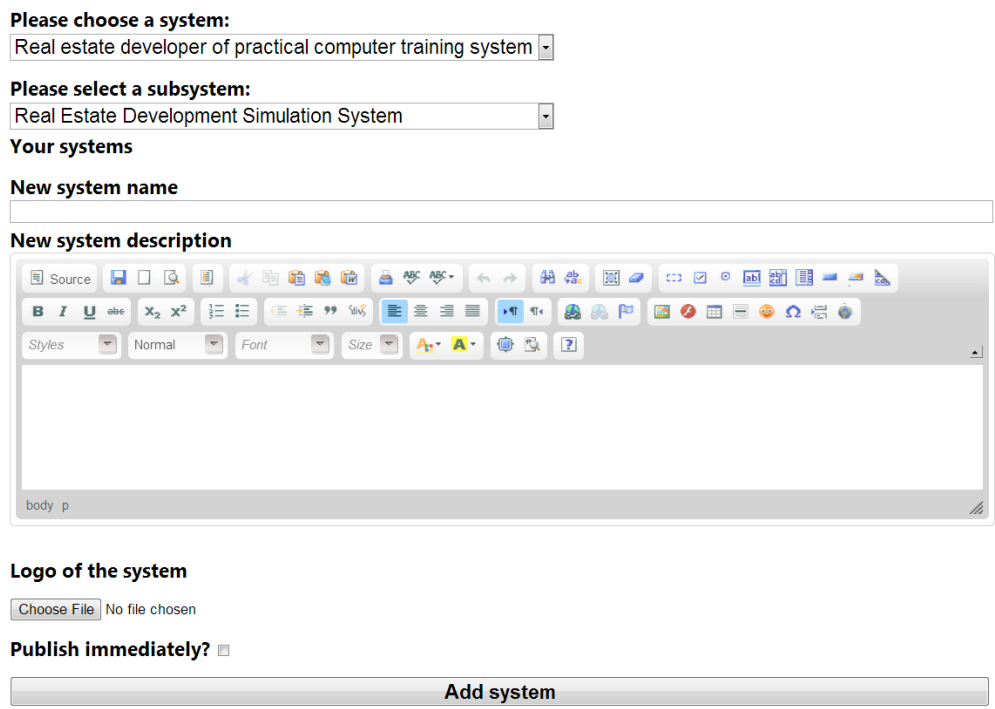

Fig. 4.17. Beginning to create new project (Created by author)

Next step is to create objects' groups. Five objects' groups in this case are created:

- Object;

- Mechanical strength / Fire Safety / Protection against noise / Energy saving and heat preservation requirements;

- Hygiene, health and environmental protection requirements;

- Use of safety;

- Sanitary requirements.

Fig. 4.18 illustrates creating window of objects' groups. 


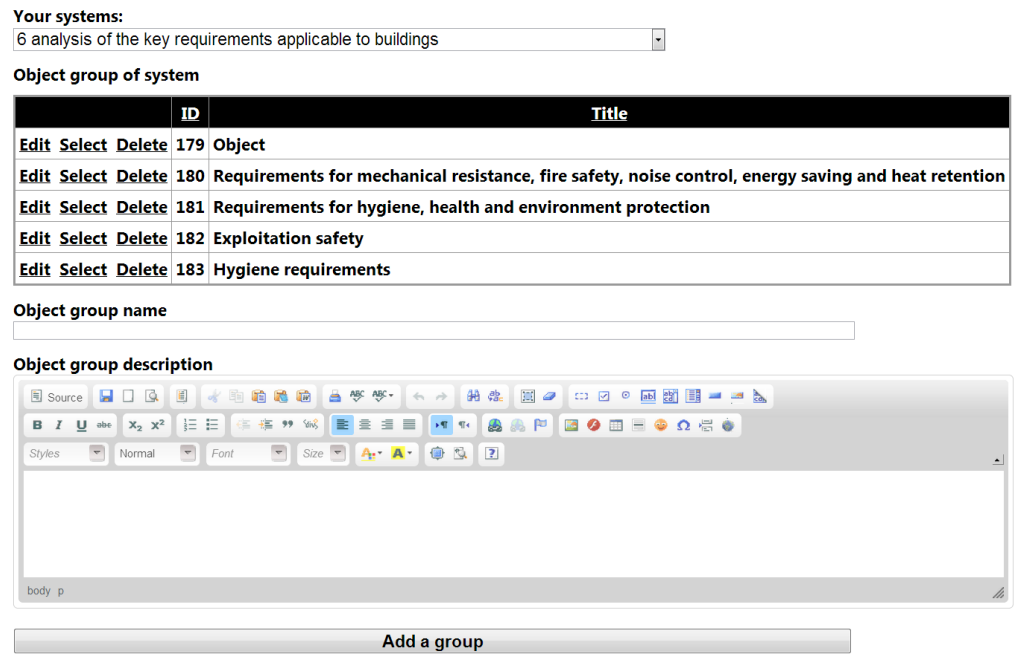

Fig. 4.18. Window of creating new objects' groups (Created by author)

After objects' groups are created it is possible to start inserting objects of objects' groups (Fig. 4.19). At this point object criteria parameters are not needed.

Appropriate title and description provide more clearance for project results' analysis. Full selected alternative documentation can be made if it is available.

Each objects' group has own criteria collection. Fig. 4.20 shows window of adding criteria to object group criteria list.

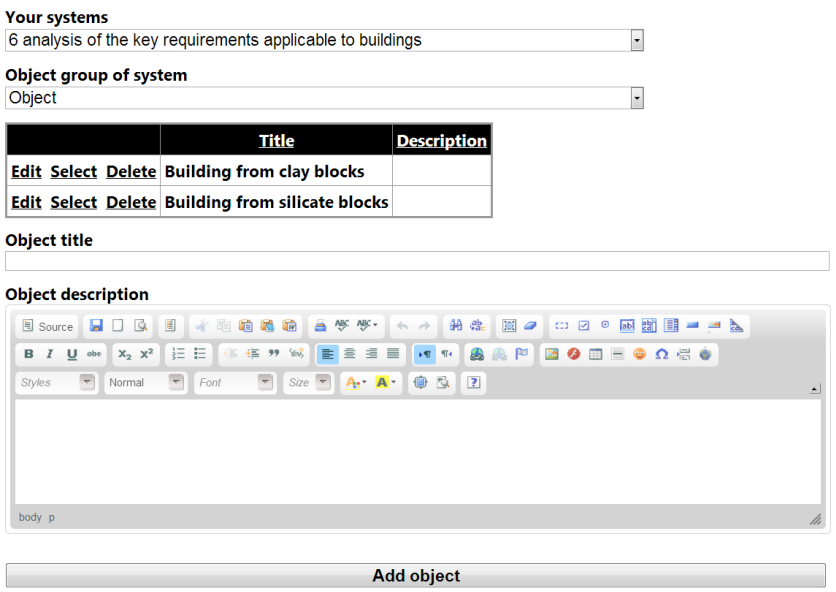

Fig. 4.19. Creating of new object in object group (Created by author) 


\begin{tabular}{|c|c|c|c|c|}
\hline \multicolumn{5}{|l|}{ Your systems: } \\
\hline \multicolumn{5}{|c|}{ Object group of system } \\
\hline \multirow[t]{2}{*}{ Object } & & & & $\nabla$ \\
\hline & Weight & Maximizing & Measure unit & Title \\
\hline Edit Select Delete & 0.34 & $\square$ & $L t / m 3$ & Price \\
\hline Edit Select Delete & 0.04 & $\square$ & $\mathrm{kg} / \mathrm{m} 3$ & Density \\
\hline Edit Select Delete & 0.03 & $\square$ & $\%$ & Water absorption as per LST $1428.18: 1997$ \\
\hline Edit Select Delete & 0.03 & $\square$ & $\%$ & Moisture absorption \\
\hline Edit Select Delete & & 四 & Points & Volume constancy \\
\hline \multicolumn{5}{|l|}{ Criteria name EN } \\
\hline \multicolumn{5}{|c|}{ Description of the criteria EN } \\
\hline \multicolumn{5}{|c|}{ Is the criteria maximizing? } \\
\hline \multicolumn{5}{|l|}{ Criteria weight } \\
\hline \multicolumn{5}{|l|}{ Measure unit } \\
\hline $\mathrm{mm}$ & & & & $\nabla$ \\
\hline & & & Add & $\square$ \\
\hline
\end{tabular}

Fig. 4.20. Adding criteria for new objects' group (Created by author)

It is very important to have both maximizing and minimizing criteria. Weight of the criteria must be calculated by method preferred by user. When all objects groups' criteria are added, last step is to add parameters of object criteria. There is an ability to insert the whole list of selected object group or add parameters one by one. Fig. 4.21 shows window of inserting and updating parameters.

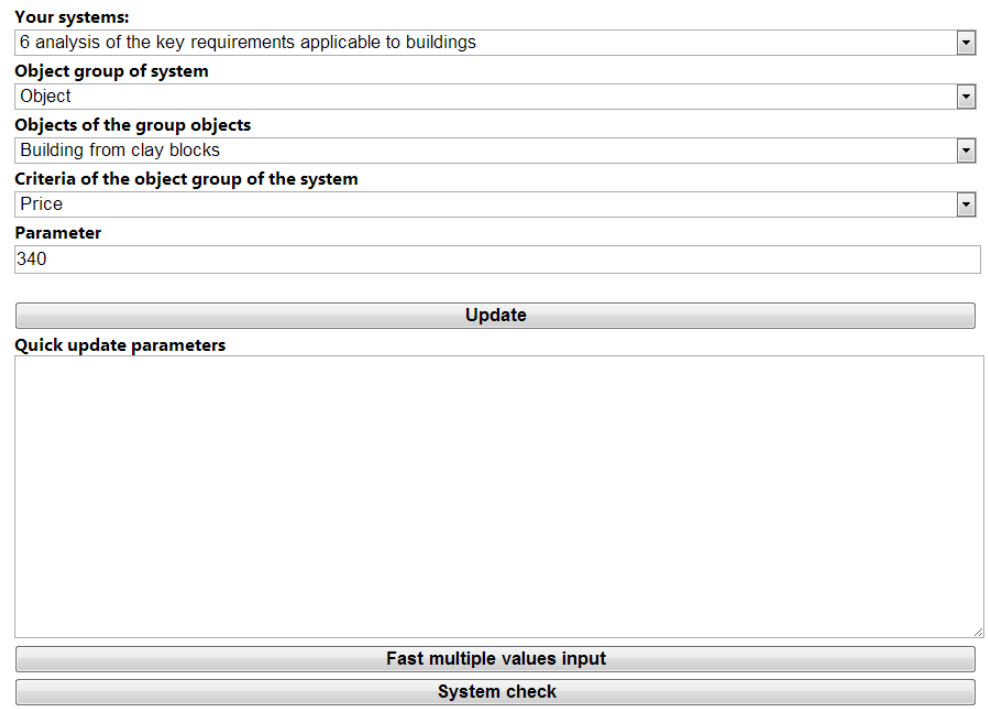

Fig. 4.21. Inserting and updating objects' parameters (Created by author) 
Fastest way is to insert or update the whole list of the group parameters. Additionally user can manually check system for error corrections.

After all parameters are inserted, it is possible to move to main page to see the created system as a result. Fig. 4.22 shows all objects in the created object group.

Select objects group

Object

Qualitative and quantitative description of the alternatives:

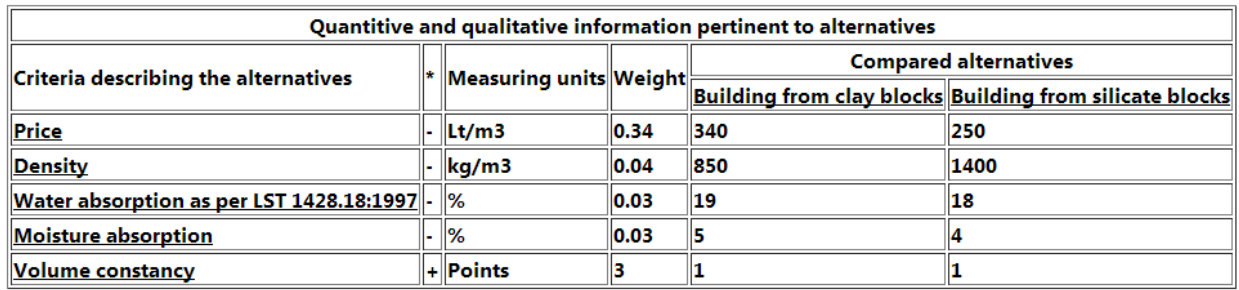

*- The sign "+/-" indicates that a greater (less) criterion value corresponds to a greater significance for a user (stakeholders)

Fig. 4.22. Objects' group "Object" primary data (Created by author)

User can be familiarized with primary data before starting of multivariant calculations. By pressing on criteria or alternative name, user can get detail description.

First step for the system calculations is multiple criteria evaluation of the object groups' alternatives. For each group significance and priority of alternatives are calculated. Further object group "Object" will be analysed as an example.

Using primary data the weighted, normalized decision-making matrix can be formed (see Table 4.9). The following formula is used for this purpose:

$$
d_{i j}=\frac{x_{i j} \cdot q_{i}}{\sum_{j=1}^{n} x_{i j}} ; i=\overline{1, m} ; j=\overline{1, n},
$$

where: $d_{i j}$ - the normalized weighted value of each criteria; $x_{i j}$ - the value of the $i^{\text {th }}$ criterion in the $j^{\text {th }}$ alternative of a object; $m$ - the number of criteria; $n$ - the number of the object alternatives compared; $q_{i}-$ weight of the $i^{\text {th }}$ criterion. 
Table 4.9. The weighted, normalized decision-making matrix for objects' alternatives

\begin{tabular}{|c|c|c|c|c|c|}
\hline \multirow{2}{*}{$\begin{array}{l}\text { Criteria describing the } \\
\text { alternatives }\end{array}$} & \multirow[t]{2}{*}{$*$} & \multirow{2}{*}{$\begin{array}{l}\text { Measuring } \\
\text { units }\end{array}$} & \multirow[t]{2}{*}{ Weights } & \multicolumn{2}{|c|}{ Analysed objects' alternatives } \\
\hline & & & & $\begin{array}{l}\text { Building from } \\
\text { clay blocks }\end{array}$ & $\begin{array}{l}\text { Building from } \\
\text { silicate blocks }\end{array}$ \\
\hline Price & - & $\mathrm{Lt} / \mathrm{m}^{3}$ & 0.34 & 0.1959 & 0.1441 \\
\hline Density & - & $\mathrm{Kg} / \mathrm{m}^{3}$ & 0.04 & 0.0151 & 0.0249 \\
\hline $\begin{array}{l}\text { Water absorption as per } \\
\text { LST } 1428.18: 1997\end{array}$ & - & $\%$ & 0.03 & 0.0154 & 0.0146 \\
\hline Moisture absorption & - & $\%$ & 0.03 & 0.0167 & 0.0133 \\
\hline Volume constancy & + & Point & 3 & 1.5 & 1.5 \\
\hline
\end{tabular}

* - Sign (+/-) shows, respectively, the better/poorer value of the criterion of requirements

In the next step the object alternatives are described by minimizing indexes $S_{-j}$ and maximizing indexes $S_{+j}$. The lower value of minimized criteria's is better and the greater value of maximized criteria's is better. The sums are calculated according to the formula (see Table 4.10):

$$
S_{+j}=\sum_{i=1}^{m} d_{+i j} ; S_{-j}=\sum_{i=1}^{m} d_{-i j} ; i=\overline{1, m} ; j=\overline{1, n} .
$$

where: $d_{-i j}$ - the normalized weighted value of minimizing criteria's; $d_{+i j}$ - the normalized weighted value of maximizing criteria's; $m$ - the number of criteria; $n-$ the number of the object alternatives compared.

Table 4.10. The weighted, normalized decision-making matrix with sums of maximizing and minimizing normalized weighted values for objects' alternatives

\begin{tabular}{|l|l|l|l|l|l|}
\hline Criteria describing the & $*$ & Measuring & Weights & \multicolumn{2}{|l|}{ Analysed objects' alternatives } \\
\cline { 3 - 5 } & & & & $\begin{array}{l}\text { Building from } \\
\text { clay blocks }\end{array}$ & $\begin{array}{l}\text { Building from } \\
\text { silicate blocks }\end{array}$ \\
\hline Price & - & $\mathrm{Lt} / \mathrm{m}^{3}$ & 0.34 & 0.1959 & 0.1441 \\
\hline Density & - & $\mathrm{Kg} / \mathrm{m}^{3}$ & 0.04 & 0.0151 & 0.0249 \\
\hline $\begin{array}{l}\text { Water absorption as per } \\
\text { LST 1428.18:1997 }\end{array}$ & - & $\%$ & 0.03 & 0.0154 & 0.0146 \\
\hline Moisture absorption & - & $\%$ & 0.03 & 0.0167 & 0.0133 \\
\hline Volume constancy & + & Point & 3 & 1.5 & 1.5 \\
\hline $\begin{array}{l}\text { Sum of maximizing normalized weighted values (ad- } \\
\left.\text { vantages of objects' alternative } S_{+}\right)\end{array}$ & 1.5 & 1.5 \\
\hline $\begin{array}{l}\text { Sum of minimizing normalized weighted values (disad- } \\
\text { vantages of objects' alternative } S_{-} \text {) }\end{array}$ & 0.2431 & 0.1969 \\
\hline
\end{tabular}

* - Sign (+/-) shows, respectively, the better/poorer value of the criterion of requirements 
The significance of the compared objects' alternative is determined by describing the characteristics of positive object alternatives ("pluses") and negative object alternatives ("minuses"). The relative significance $Q_{j}$ of each object alternative is found according to the formula:

$$
Q_{j}=S_{+j}+\frac{S_{-\min } \cdot \sum_{j=1}^{n} S_{-j}}{S_{-j} \cdot \sum_{j=1}^{n} \frac{S_{-\min }}{S_{-j}}} ; j=\overline{1, n} .
$$

where: $\mathrm{Q}_{j}$ - significance of the compared object alternative; $\mathrm{S}_{+j}-$ the sum of maximizing normalized weighted values; $\mathrm{S}_{-j}$ - the sum of minimizing normalized weighted values; $\mathrm{S}_{-\min }-$ the minimal $\mathrm{S}_{-j}$ value of all object alternatives; $n-$ the number of the object alternatives compared.

The priorities of the objects' alternatives are determined by comparing the significances of the objects' alternatives. The greater is the $Q_{j}$ the higher is the priority.

The degree of objects' alternative utility is determined by comparing the analysed object alternative with the most efficient object. In this case, all the utility degree values related to the project analysed will range from $0 \%$ to $100 \%$. This will facilitate a visual assessment of the project's efficiency (see Table 4.11).

Table 4.11. The weighted, normalized decision-making matrix with the determined priorities for objects' alternatives

\begin{tabular}{|l|l|l|l|l|l|}
\hline $\begin{array}{l}\text { Criteria describing the } \\
\text { alternatives }\end{array}$ & $*$ & $\begin{array}{l}\text { Measuring } \\
\text { units }\end{array}$ & Weights & \multicolumn{2}{|l|}{ Analysed objects' alternatives } \\
\cline { 3 - 5 } & & & $\begin{array}{l}\text { Building from } \\
\text { clay blocks }\end{array}$ & $\begin{array}{l}\text { Building from } \\
\text { silicate blocks }\end{array}$ \\
\hline Price & - & $\mathrm{Lt} / \mathrm{m}^{3}$ & 0.34 & 0.1959 & 0.1441 \\
\hline Density & - & $\mathrm{Kg} / \mathrm{m}^{3}$ & 0.04 & 0.0151 & 0.0249 \\
\hline $\begin{array}{l}\text { Water absorption as per } \\
\text { LST 1428.18:1997 }\end{array}$ & - & $\%$ & 0.03 & 0.0154 & 0.0146 \\
\hline Moisture absorption & - & $\%$ & 0.03 & 0.0167 & 0.0133 \\
\hline Volume constancy & + & Point & 3 & 1.5 & 1.5 \\
\hline Sum of maximizing normalized weighted values $\left(S_{+}\right)$ & 1.5 & 1.5 \\
\hline \multicolumn{2}{|l|}{ Sum of minimizing normalized weighted values $\left(S_{-}\right)$} & 0.2431 & 0.1969 \\
\hline \multicolumn{2}{|l|}{ The significance of the objects' alternative $\left(Q_{\mathrm{j}}\right)$} & 1.6969 & 1.7431 \\
\hline \multicolumn{2}{|l|}{ The priorities of the objects' alternatives } & 2 & 1 \\
\hline \multicolumn{2}{|l|}{ Utility degree of the object alternative $(\%)$} & 97.35 & 100 \\
\hline
\end{tabular}

* - Sign (+/-) shows, respectively, the better/poorer value of the criterion of requirements 
The formula used for calculating object alternative utility degree $N_{j}$ is the following:

$$
N_{j}=\frac{Q_{j}}{Q_{\max }} \cdot 100 \% .
$$

where: $N_{j}$ - the degree of $j^{\text {th }}$ object alternative utility; $Q_{j}$ - the relative significance of $j^{\text {th }}$ object alternative; $Q_{\max }-$ the most efficient relative significance from the existing object alternatives.

Fig. 4.23 shows real system result of multi objective assessment of the alternatives for first objects' group. Results show that object "Building from silicate blocks" is prior to "Building from clay blocks". It is possible to try checking if change of parameters will change objects' priority. For example, it is possible to try minimizing of price of object with priority 2. For this purpose system uses method proposed in Chapter 2.2.3. As shown in Fig. 4.24, only one price approximation cycle is required for object "Building from clay blocks" to get priority 1 . Price is reduced to $250 \mathrm{Lt} / \mathrm{m}^{3}$ and it is enough to make "Building from clay blocks" more attractive.

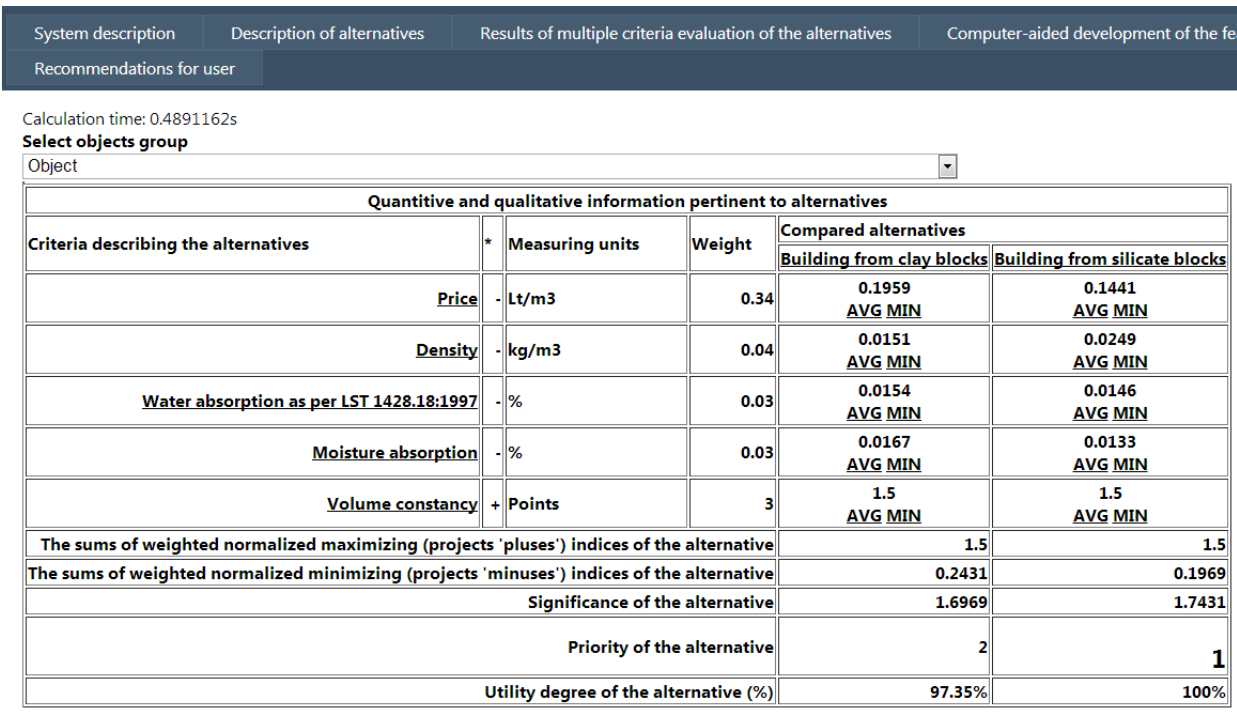

*- The sign "+/-" indicates that a greater (less) criterion value corresponds to a greater significance for a user (stakeholders)

Fig. 4.23. Multi objective assessment of the alternatives for first objects' group (Created by author) 


\begin{tabular}{|r|r|r|r|r|}
\hline Approximation cycle & The corrected value & $\begin{array}{l}\text { It is determined whether the corrected value being } \\
\text { valuated had been calculated accurately enough }\end{array}$ & Correction influence \\
\hline \hline 0 & 340 & $26.47 \%$ & $2.6162 \%$ \\
\hline 1 & 250 & $0 \%$ & $0 \%$ \\
\hline
\end{tabular}

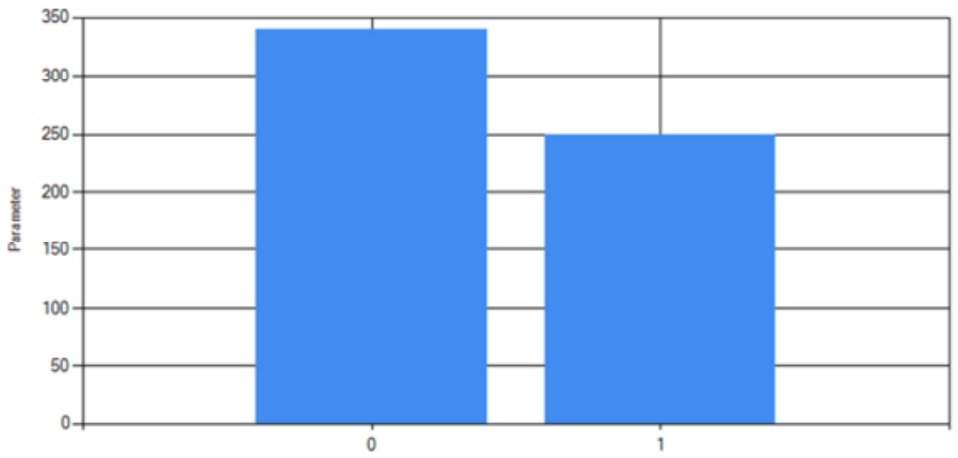

\begin{tabular}{|l||l|l|l|l||}
\hline \multicolumn{5}{|c|}{ Cycle } \\
\hline Criterions $\backslash$ IObjects & Significance & Building from clay blocks & Building from silicate blocks \\
\hline Price & 0.34 & - & 0.1959 & 0.1441 \\
\hline Density & 0.04 & - & 0.0151 & 0.0249 \\
\hline Water absorption as per LST 1428.18:1997 & 0.03 & - & 0.0154 & 0.0146 \\
\hline Moisture absorption & 0.03 & - & 0.0167 & 0.0133 \\
\hline Volume constancy & 3 & + & 1.5 & 1.5 \\
\hline S+ & 1.5 & 1.5 \\
\hline S. & 0.2431 & 0.1969 \\
\hline Q & 1.6969 & 1.7431 \\
\hline P & 2 & 1 \\
\hline $\mathrm{N}$ & $97.35 \%$ & $100 \%$ \\
\hline
\end{tabular}

\begin{tabular}{|l|l|l|l|l||}
\hline Criterions IIObjects & Significance & Building from clay blocks & Building from silicate blocks \\
\hline Price & 0.34 & - & 0.17 & 0.17 \\
\hline Density & 0.04 & - & 0.0151 & 0.0249 \\
\hline Water absorption as per LST 1428.18:1997 & 0.03 & - & 0.0154 & 0.0146 \\
\hline Moisture absorption & 0.03 & - & 0.0167 & 0.0133 \\
\hline Volume constancy & 3 & + & 1.5 & 1.5 \\
\hline $\mathrm{S}_{+}$ & 1.5 & 1.5 \\
\hline $\mathrm{S}$ & & 0.2172 & 0.2228 \\
\hline $\mathrm{Q}$ & 1.7228 & 1.7172 \\
\hline $\mathrm{P}$ & 1 & 2 \\
\hline $\mathrm{N}$ & $100 \%$ & $99.67 \%$ \\
\hline
\end{tabular}

Fig. 4.24. Object criteria optimization (Created by author)

Fig. 4.23 shows priority calculations only for one group. If multivariant solution is needed, at least 2 groups of objects should be analysed. In provided example, there are five different groups of objects. For this purpose system uses method proposed in Chapter 2.2.2. Results of multivariant calculations are provided in Fig. 4.25. 
Calculation time: $0.0671013 \mathrm{~s}$

Number of possible alternatives: 5832

\begin{tabular}{|c|c|c|c|c|c|c|c|c|}
\hline \multirow{6}{*}{$\begin{array}{l}\text { Criteria } \\
\text { describing the } \\
\text { alternatives }\end{array}$} & & \multirow{6}{*}{$\begin{array}{l}\text { Measuring } \\
\text { units }\end{array}$} & \multirow{6}{*}{ Weight } & \multirow{6}{*}{\begin{tabular}{|l}
$\frac{1215}{1218}$ \\
$\frac{1230}{1235}$ \\
1244 \\
\end{tabular}} & \multirow{6}{*}{\begin{tabular}{|l|}
$\frac{1215}{1216}$ \\
$\frac{1230}{1235}$ \\
1244 \\
\end{tabular}} & \multirow{6}{*}{\begin{tabular}{|l|}
$\frac{1215}{1218}$ \\
$\frac{1230}{1238}$ \\
1244 \\
\end{tabular}} & \multirow{6}{*}{\begin{tabular}{|l|}
$\frac{1215}{1218}$ \\
$\frac{1225}{1235}$ \\
1244 \\
\end{tabular}} & \multirow{6}{*}{\begin{tabular}{|l|}
$\frac{1215}{1216}$ \\
$\frac{1230}{1238}$ \\
1244 \\
\end{tabular}} \\
\hline & & & & & & & & \\
\hline & & & & & & & & \\
\hline & & & & & & & & \\
\hline & & & & & & & & \\
\hline & & & & & & & & \\
\hline Price & - & $\mathrm{Lt} / \mathrm{m} 3$ & 0.34 & 0.009004 & 0.009004 & 0.009004 & 0.009004 & 0.009004 \\
\hline Density & - & $\mathrm{kg} / \mathrm{m} 3$ & 0.04 & 0.001556 & 0.001556 & 0.001556 & 0.001556 & 0.001556 \\
\hline $\begin{array}{l}\text { Water } \\
\text { absorption as } \\
\text { per LST } \\
1428.18: 1997 \\
\end{array}$ & - & $\%$ & 0.03 & 0.000912 & 0.000912 & 0.000912 & 0.000912 & 0.000912 \\
\hline $\begin{array}{l}\text { Moisture } \\
\text { absorption }\end{array}$ & - & $\%$ & 0.03 & 0.000833 & 0.000833 & 0.000833 & 0.000833 & 0.000833 \\
\hline $\begin{array}{l}\text { Volume } \\
\text { constancy }\end{array}$ & + & Points & 3 & 0.09375 & 0.09375 & 0.09375 & 0.09375 & 0.09375 \\
\hline \multicolumn{9}{|c|}{ 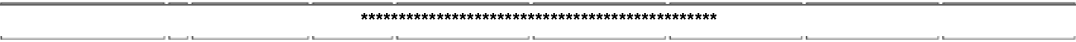 } \\
\hline $\begin{array}{l}\text { Pollution by } \\
\text { construction } \\
\text { products }\end{array}$ & + & Points & 0.03 & 0.000882 & 0.000882 & 0.000882 & 0.000882 & 0.000882 \\
\hline $\begin{array}{l}\text { Environmental } \\
\text { pollutants }\end{array}$ & + & Points & 0.03 & 0.00101 & 0.00101 & 0.00101 & 0.00101 & 0.00101 \\
\hline $\begin{array}{l}\text { Pollutants } \\
\text { from humans, } \\
\text { animals and } \\
\text { plants }\end{array}$ & & Points & 0.03 & 0.001 & 0.001 & 0.001 & 0.001 & 0.001 \\
\hline \multicolumn{4}{|c|}{$\begin{array}{l}\text { The sums of weighted normalized } \\
\text { maximizing (projects 'pluses') } \\
\text { indices of the alternative }\end{array}$} & 0.17753 & 0.177626 & 0.178625 & 0.175701 & 0.178721 \\
\hline \multicolumn{4}{|c|}{$\begin{array}{l}\text { The sums of weighted normalized } \\
\text { minimizing (projects 'minuses') } \\
\text { indices of the alternative }\end{array}$} & 0.051141 & 0.052272 & 0.053453 & 0.051141 & 0.054584 \\
\hline \multicolumn{4}{|c|}{ Significance of the alternative } & 0.23679708 & 0.23561073 & 0.23532861 & 0.23496808 & 0.23424969 \\
\hline \multicolumn{4}{|c|}{ Priority of the alternative } & 1 & 2 & 3 & 4 & 5 \\
\hline \multicolumn{4}{|c|}{ Utility degree of the alternative (\%) } & $100 \%$ & $99.5 \%$ & $99.38 \%$ & $99.23 \%$ & $98.92 \%$ \\
\hline
\end{tabular}

Fig. 4.25. Results of multivariant calculations (Created by author)

Fig. 4.25 shows that best alternative is set of objects $(1215,1218,1230$, 1235 and 1244). It is possible to get detail recommendations report for object group to see if it is possible to make one or another object more attractive (Fig. 4.26). 


\begin{tabular}{|c|c|c|c|c|}
\hline Object & & & & $\nabla$ \\
\hline \multicolumn{5}{|c|}{ Quantitive and qualitative information pertinent to alternatives } \\
\hline \multirow[t]{2}{*}{ Criteria describing the alternatives } & \multirow[t]{2}{*}{ * Measuring units } & \multirow[t]{2}{*}{ Weight } & \multicolumn{2}{|c|}{$\begin{array}{l}\text { Compared alternatives } \\
\text { Possible improvement of the analysed criterion in \% } \\
\text { Possible increase of the market value of the alternative in \% } \\
\text { through increased value of the aforementioned criterion }\end{array}$} \\
\hline & & & Building from clay blocks & Building from silicate blocks \\
\hline Price & - $L t / \mathbf{m} 3$ & 0.34 & \begin{tabular}{|l|}
340 \\
$(26.47 \%)$ \\
$(2.6163 \%)$ \\
\end{tabular} & \begin{tabular}{|l|}
250 \\
$(0 \%)$ \\
$(0 \%)$
\end{tabular} \\
\hline Density & $\mathrm{kg} / \mathrm{m} 3$ & 0.04 & $\begin{array}{l}550 \\
(0 \%) \\
(0 \%)\end{array}$ & \begin{tabular}{|l}
1400 \\
$(39.29 \%)$ \\
$(0.4568 \%)$
\end{tabular} \\
\hline Water absorption as per LST 1428.18:1997 & $\%$ & 0.03 & \begin{tabular}{|l|}
19 \\
$(5.26 \%)$ \\
$(0.0459 \%)$ \\
\end{tabular} & \begin{tabular}{|l|}
18 \\
$(0 \%)$ \\
$(0 \%)$ \\
\end{tabular} \\
\hline Moisture absorption & - $\%$ & 0.03 & \begin{tabular}{|l|}
5 \\
$(20 \%)$ \\
$(0.1744 \%)$
\end{tabular} & $\begin{array}{l}4 \\
(0 \%) \\
(0 \%)\end{array}$ \\
\hline Volume constancy & + Points & 3 & \begin{tabular}{|l|}
1 \\
$(0 \%)$ \\
$(0 \%)$
\end{tabular} & \begin{tabular}{|l}
1 \\
$(0 \%)$ \\
$0 \%)$
\end{tabular} \\
\hline
\end{tabular}

*- The sign " +/-" indicates that a greater (less) criterion value corresponds to a greater significance for a user (stakeholders) TOP 3 object criterions that have greatest influence on ranking

\begin{tabular}{|c|c|c|c|}
\hline \multicolumn{4}{|c|}{ Building from clay blocks } \\
\hline Position & $\begin{array}{l}\text { Criteria describing the } \\
\text { alternatives }\end{array}$ & $\begin{array}{l}\text { Possible improvement of the analysed } \\
\text { criterion in } \%\end{array}$ & $\begin{array}{l}\text { Possible increase of the market value of the } \\
\text { alternative in \% } \\
\text { through increased value of the aforementioned } \\
\text { criterion }\end{array}$ \\
\hline & Price & $26.47 \%$ & $2.6163 \%$ \\
\hline 2 & Moisture absorption & $20 \%$ & $0.1744 \%$ \\
\hline & $\begin{array}{l}\text { Water absorption as per LST } \\
\text { 1428.18:1997 }\end{array}$ & $5.26 \%$ & $0.0459 \%$ \\
\hline
\end{tabular}

\begin{tabular}{|c|c|c|c|}
\hline \multicolumn{4}{|c|}{ Building from silicate blocks } \\
\hline Position & $\begin{array}{l}\text { Criteria describing the } \\
\text { alternatives }\end{array}$ & $\begin{array}{l}\text { Possible improvement of the analysed } \\
\text { criterion in } \%\end{array}$ & $\begin{array}{l}\text { Possible increase of the market value of the } \\
\text { alternative in } \% \\
\text { through increased value of the aforementioned } \\
\text { criterion }\end{array}$ \\
\hline 1 & Density & $39.29 \%$ & $0.4568 \%$ \\
\hline 2 & Price & $0 \%$ & $0 \%$ \\
\hline 3 & & $0 \%$ & $0 \%$ \\
\hline
\end{tabular}

Fig. 4.26. Recommendations for object group (Created by author)

For "Building from clay blocks" object main three criteria that have greatest influence on ranking are: Price, Moisture absorption and Water absorption as per LST 1428.18:1997. For second object, only one criteria optimization (Density) has influence on ranking.

It can be summarized that BECLS provides an opportunity for the specialists of built environment (students) to make their decisions on project management in fast and convenient way. The importance of these parameters to work efficiency was also emphasized by Maqsood et al. (2006). Transfer of best practice in the system is ensured by use of criteria systems provided by experts. This gives an opportunity to make individual calculations for comparison of alternatives. Maqsood et al. (2006) also argues that experience in solving practical tasks is transferred better than in case of reading the study material. In the developed system both approaches are used. 


\subsection{Conclusions for Chapter 4}

1. The developed Intelligent Tutoring System for Built Environment is practically applied in study process at Vilnius Gediminas Technical University, in Construction Technology and Management as well as Real Estate Management master study programmes. During the testing of the system 340 students were registered and used the system.

2. Individualization of students' tutoring was practically implemented both in providing study material and testing knowledge acquired by student.

3. Analysis of approximately 100 built environment projects' alternatives was performed by using Built Environment Computer Learning Subsystem (BECLS).

4. Analysis of historical data statistics from the developed system revealed that more than $50 \%$ of students took self tests 3 or more times. This allows come to conclusion that self-testing function of Intelligent Tutoring System for Built Environment is significant to students in learning process. 



\section{General Conclusions}

1. Analysis of scientific literature proved the novelty of the solution proposed in dissertation. Solution integrates multivariant design into tutoring processes - it, as known by author, was never researched and practically implemented before.

2. Model of the Intelligent Tutoring System for Built Environment was developed for the first time. It is novel due to:

- Adaptive and personalized learning and testing is performed according to the student's curiosity, preferred difficulty levels and psychological condition;

- Personalized search is available as there is a possibility to create a lot of learning alternatives and to select the best one according to individual student needs;

- The possibility to analyse, assess a lot of alternatives and select the best one while preparing homeworks, course projects and final works is ensured.

3. The prototype of Intelligent Tutoring System for Built Environment was developed and tested. The main results are as follows: 
- Time needed for creating built environment project and best alternative selection was reduced more than 10 times, according experimental tests results;

- During the testing approximately 100 new or modified built environment projects were created by students;

- Students tested more than 1000 personalized learning alternatives and passed self tests;

- Analysis revealed that students who had passed self-testing before exam at least two times got approximately 1 point higher mark than whose who hadn't. 


\section{References}

Alexandrov, V. N.; Dimov, I. T.; Karaivanova, A.; Tan, C. J. K. 2003. Parallel Monte Carlo algorithms for Information Retrieval, Mathematics and Computers in Simulation 62(3-6): 289-295.

AlFallay, I. 2004. The role of some selected psychological and personality traits of the rater in the accuracy of self- and peer-assessment, System 32(3): 407-425.

Ammar, M. B.; Neji, M.; Alimi, A. M.; Gouarderes, G. 2010. The affective tutoring system, Expert Systems with Applications 37(4): 3013-3023.

Anderson, J. R. 2012. Tracking problem solving by multivariate pattern analysis and hidden markov model algorithms, Neuropsychologia 50(4): 487-498.

Arkin, H.; Paciuk, M. 1997. Evaluating intelligent building according to level of service system integration, Automation in Construction 6(5-6): 471-479.

Armani, B.; Bertino, E.; Catania, B.; Laradi, D.; Marin, B. Zarri, G. P. 2010. Repository Management in an Intelligent Indexing Approach for Multimedia Digital Libraries, in S. Ohsuga, Z. W. Raś (Eds.), Foundations of Intelligent Systems, Lecture Notes in Computer Science 1932: 431-440. Springer, Heidelberg.

Austin, Z.; Gregory, P. A. M.; Galli, M. 2008. I just don't know what I'm supposed to know: evaluating self-assessment skills of international pharmacy graduates in Canada, Research in Social and Administrative Pharmacy 4(2): 115-124.

Bahra, N. 2001. Competitive Knowledge Management. New York: Palgrave. 258 p. 
Ballantine, J. A.; McCourt Larres, P.; Oyelere, P. 2007. Computer usage and the validity of self-assessed computer competence among first-year business students, Computers \& Education 49(4): 976-990.

Baniasa, G.; Achillasa, Ch.; Vlachokostasa, Ch.; Moussiopoulosa, N.; Papaioannou, I. 2011. A web-based Decision Support System for the optimal management of construction and demolition waste, Waste Management 31(12): 2497-2502.

Barlow, J. D. 1969. Pupillary size as an index of preference in political candidates, Perceptual and Motor Skills 28: 927-932.

Bartuska, T. J.; Young, G. L.; McClure, W. R. (Eds.). 2007. The built environment: A collaborative inquiry into design and planning. 2nd Ed. Wiley, John \& Sons. 424 p.

Barton, J. S. 1997. Smart structures and materials: Brian Culshaw, Optics and Lasers in Engineering 27(3): 337-338.

Ben Ammar, M.; Neji, M.; Alimi, A. M.; Gouardères, G. 2010. The affective tutoring system, Expert Systems with Applications 37(4): 3013-3023.

Bindu Madhuri, Ch.; Anand Chandulal, J.; Padmaja, M. 2010. Selection of Best Web Site by Applying COPRAS-G method, International Journal of Computer Science and Information Technologies 1(2):138-146.

Braak, J. P. V. 2004. Domains and determinants of university students' self-perceived computer competence, Computer Education 43(3): 299-312.

Broderick, P. 2006. Smart growth calls for street smarts: latest projects serve as a catalyst, provide creativity to community, San Diego Business Journal 27(29): 20-23.

Brusilovsky, P. 2000. Course Sequencing for Static Courses? Applying ITS Techniques in Large-Scale Web-Based Education, in G. Gauthier, K. VanLehn, C. Frasson (Eds.), Intelligent Tutoring Systems, Lecture Notes in Computer Science 1839: 19-23. Springer, Heidelberg.

Brusilovsky, P.; Peylo, C. 2003. Adaptive and intelligent web-based educational systems, International Journal of Artificial Intelligence in Education 13(2-4): 156-169.

Bushby, S. T. 1997. BACnet: a standard communication infrastructure for intelligent buildings, Automation in Construction 6(5-6): 529-540.

Carrillo, P. 2004. Managing knowledge: lessons from the oil and gas sector, Construction Management and Economics 22(6): 631-642.

Chatterjee, P.; Athawaleb, V. M.; Chakraborty, S. 2011. Materials selection using complex proportional assessment and evaluation of mixed data methods, Materials \& Design 32(2): 851-860.

Chen, Z.; Clements-Croome, D.; Hong, J.; Li, H.; Xu, Q. 2006. A multicriteria lifespan energy efficiency approach to intelligent building assessment, Energy and Buildings 38(5): 393-409.

Chinese, D.; Nardin, G.; Saro, O. 2011. Multi-criteria analysis for the selection of space heating systems in an industrial building, Energy 36(1): 556-565. 
Collinson, H. 1995. Help: working smarter lock, stock and password, Computers \& Security 14(1): 39.

Crowe, N. 1997. Nature and the idea of a man-made World: An investigation into the evolutionary roots of form and order in the built environment. The MIT Press. 290 p.

Dasa, M. C.; Sarkarb, B.; Ray, S. 2011. A framework to measure relative performance of Indian technical institutions using integrated fuzzy AHP and COPRAS methodology, Socio-Economic Planning Sciences http://dx.doi.org/10.1016/j.seps.2011.12.001.

Datta, S.; Beriha, G. S.; Patnaik, B.; Mahapatra, S. S. 2009. Use of compromise ranking method for supervisor selection: A multi-criteria decision making (MCDM) approach, International Journal of Vocational and Technical Education 1(1): 7-13.

Day, M. Y.; Lu, C.; Yang, J. D.; Chiou, G.; Ong, C. S.; Hsu, W. 2005. Designing an ontology-based intelligent tutoring agent with instant messaging, in Proc. of The Fifth IEEE International Conference on Advanced Learning Technologies, 5-8 July, 2005, Kaohsiung, Taiwan, 318-320.

DeTienne, K. B.; Jensen R. B. 2001. Intranets and business model innovation: managing knowledge in the virtual organization, in Y. Malhotra (Ed.), Knowledge Management and Business Model Innovation. Hershey: Idea Group Publishing, 198-215.

D'Mello, S.; Olney, A.; Williams, C.; Hays, P. 2012. Gaze tutor: A gaze-reactive intelligent tutoring system, International Journal of Human-Computer Studies 70(5): 377398.

Dolšak, B.; Novak, M. 2011. Intelligent decision support for structural design analysis, Advanced Engineering Informatics 25(2): 330-340.

Escudero, H.; Fuentes, R. 2010. Exchanging courses between different Intelligent Tutoring Systems: A generic course generation authoring tool, Knowledge-Based Systems 23(8): 864-874.

Essex, D. 2003. Who knew dust could be so smart?, Government Computer News 22(34): 33-34.

Fitzgerald, J. T.; White, C. B.; Gruppen, L. D. 2003. A longtitudinal study of selfassessment accuracy, Medical Education 37: 645-649.

Gaining Competitive Advantage for the Refurbishment Market within the West Midlands. 2006. UK: West Midlands Centre for Constructing Excellence. 15 p.

Ginevičius, R.; Podvezko, V. 2008. Multicriteria Evaluation of Lithuanian Banks from the Perspective of their Reliability for clients, Journal of Business Economics and Management 9(4): 257-267.

Glanz, K.; Kegler, M. C. 2007. Environments: theory, research and measures of the built environment [online], Available from Internet: <http://dccps.nci.nih.gov/>. [accessed 0907 2010].

Guillemin, A.; Morel, N. 2001. An innovative lighting controller integrated in a self adaptive building control system, Energy and Buildings 33(5): 477-487. 
Gutierrez, F.; Atkinson, J. 2011. Adaptive feedback selection for intelligent tutoring systems, Expert Systems with Applications 38(5): 6146-6152.

Gutwin, C.; Paynter, G.; Witten, I.; Neville, M. C.; Frank, E. 1999. Improving Browsing in Digital Libraries with Key-phrase Indexes, Decision Support Systems 27(1-2): 81104.

Günel, K.; Aşliyan, R. 2010. Extracting learning concepts from educational texts in intelligent tutoring systems automatically, Expert Systems with Applications 37(7): 50175022.

Hatzilygeroudis, I.; Prentzas, J. 2004. Using a hybrid rule-based approach in developing an intelligent tutoring system with knowledge acquisition and update capabilities, Expert systems with applications 26(4): 477-492.

Hsinchun, C.; Yi-Ming, C.; Ramsey, M.; Yang, C. C. 1998. An Intelligent Personal Spider (Agent) for Dynamic Internet/Intranet Searching, Decision Support Systems 23(1): 41-58.

Jeremić, Z.; Jovanović, J.; Gašević, D. 2012. Student modeling and assessment in intelligent tutoring of software patterns, Expert Systems with Applications 39(1): 210-222.

Kaklauskas, A. 1999. Multiple criteria decision support of building life cycle. Research report presented for habilitation. Technological sciences, civil engineering (02T). Vilnius: Technika. $118 \mathrm{p}$.

Kaklauskas, A.; Ditkevicius, R.; Gargasaite, L. 2006a. Intelligent tutoring system for real estate management, International Journal of Strategic Property Management 10(2): $113-130$.

Kaklauskas, A.; Kaklauskas, G.; Krutinis, M; Ditkevicius, R. 2005a. Intelligence computer learning systems in VGTU, in The 6th International Scientific Conference "Public relation, quality, benefits and risks”, Riga, Latvia, 99-104.

Kaklauskas, A.; Vainiūnas, P.; Vlasenko, A. 2008a. Intelligent voice stress analysis system for e-examination and studies efficiency monitoring, in Proc. of The 6th AECEF Symposium on Civil Engineering Education in Changing Europe, 28-30 May, 2008, Vilnius, Lithuania, 49-55.

Kaklauskas, A.; Vlasenko, A.; Amaratunga, D. 2008b. Biometrics technologies, intelligent library and tutoring system within the EURASIA project, in Proc. of The CIB international conference on building education and research "Building resilience", 11-15 February, 2008, Heritance Kandalama, Sri Lanka, 1663-1671.

Kaklauskas, A.; Zavadskas, E. K. 2007a. Decision support system for innovation with a special emphasis on pollution, International Journal of Environment and Pollution 30(3-4): 518-528.

Kaklauskas, A.; Zavadskas, E. K.; Ambrasas, G. 1998. Increase of student study efficiency through the application of multiple criteria decision support systems, in Monash Engineering Education Series. Seminar Proceeding, 2nd Baltic Region Seminar on Engineering Education Riga Technical University, 128-134. 
Kaklauskas, A.; Zavadskas, E. K.; Ditkevicius, R. 2006b. An intelligent tutoring system for construction and real estate management master degree studies, in Cooperation Design, Visualization, and Engineering, Lecture Notes in Computer Science 4101: 174181. Springer, Heidelberg.

Kaklauskas, A.; Zavadskas, E. K. 2009. Theories of investment in property: use of information, knowledge and intelligent technologies, In Les Ruddock (Ed.), Economics for the modern built environment. Taylor \& Francis: 249-268.

Kaklauskas, A.; Zavadskas, E. K.; Naimavicienè, J.; Krutinis, M.; Plakys, V.; Venskus, D. 2010b Model for a complex analysis of intelligent built environment, Automation in Construction 19(3): 326-340.

Kaklauskas, A.; Zavadskas, E. K.; Pruskus, V.; Vlasenko, A.; Bartkiene, L.; Paliskiene, R.; Zemeckyte, L.; Gerstein, V.; Dzemyda, G.; Tamulevicius, G. 2011b. Recommended biometric stress management system, Expert systems with applications 38(5): 1-15.

Kaklauskas, A.; Zavadskas, E. K.; Raslanas, S. 2005b. Multivariant design and multiple criteria analysis of building refurbishments, Energy and Buildings 37(4): 361-372.

Kaklauskas, A.; Zavadskas, E. K.; Raslanas, S.; Ginevicius, R.; Komka, A.; Malinauskas, P. 2006d. Selection of low -e windows in retrofit of public buildings by applying multiple criteria method COPRAS: A Lithuanian case, Energy and Buildings 38(5): 454-462.

Kaklauskas, A.; Zavadskas, E. K.; Trinkūnas, V. 2007c. A multiple criteria decision support on-line system for construction, Engineering Applications of Artificial Intelligence 20(2): 163-175.

Kamara, J. M.; Chimay, A. J.; Carillo, P. M. 2002. ACLEVER approach to selecting a knowledge management strategy, International Journal of Project Management 20(3): 205-211.

Kanapeckienè, L.; Kaklauskas, A.; Zavadskas, E. K.; Raslanas S. 2011. Method and system for Multi-Attribute Market Value Assessment in analysis of construction and retrofit projects, Expert Systems with Applications 38(11): 14196-14207.

Kapetanios, E. 2008. Quo Vadis computer science: from Turing to personal computer, personal content and collective intelligence, Data and Knowledge Engineering 67(2): 286-292.

Karbassi, A. R.; Abduli, M. A.; Neshastehriz, S. 2008. Energy saving in Tehran international flower exhibition's building, International Journal of Environmental Research 2(1): 75-86.

Kleinberger, T.; Becker, M.; Ras, E.; Holzinger, A.; Müller, P. 2007. Ambient intelligence in assisted living: enable elderly people to handle future interfaces, Lecture Notes in Computer Science 4555: 103-112.

Kohnle, J.; Wolff, A. 2007. Intelligent drug delivery from the oral cavity, Medical Device Technology 18(2): 44-45. 
Komarraju, M.; Karau, S. J.; Schmeck, R. R. 2009. Role of the Big Five personality traits in predicting college students' academic motivation and achievement, Learning and Individual Differences 19(1): 47-52.

Kua, H. W.; Lee, S. E. 2002. Demonstration intelligent building - a methodology for the promotion of total sustainability in the built environment, Building and Environment 37(3): 231-240.

Kummert M.; André, P.; Nicolas, J. 2001. Optimal heating control in a passive solar commercial building, Solar Energy 69(6): 103-116.

Lam Po Tang, S.; Stylios, G. K. 2006. An overview of smart technologies for clothing design and engineering, International Journal of Clothing Science and Technology 18(2): 118-137.

Lawrence, D. L.; Low, S. M. 1990. The built environment and spatial form, Annual Review of Anthropology 19: 453-505.

Litman, D. J.; Forbes-Riley, K. 2006. Recognizing student emotions and attitudes on the basis of utterances in spoken tutoring dialogues with both human and computer tutors, Speech communication 48(5): 559-590.

Leontidis, M.; Halatsis, C. 2009. Integrating learning styles and personality traits into an affective model to support learner's learning, Lecture Notes in Computer Science 5686: $225-234$.

Lucence, J. Jakarta Lucene Text Search Engine in Java [online], Available from Internet: <http://jakarta.apache.org/lucene/docs/index.html>. [accessed 2301 2010].

Maitya, S. R.; Chatterjeeb, P.; Chakraborty, S. 2012. Cutting tool material selection using grey complex proportional assessment method, Materials \& Design 36: 372-378.

Maqsood, T.; Finegan, A.; Walker, D. 2006. Applying project histories and project learning through knowledge management in an Australian construction company, Learning Organization 13(1): 80-95.

Mallak L. A.; Lyth D. M.; Olson S. D.; Ulshafer S. M.; Sardone F. J. 2003. Culture, the built environment and healthcare organizational performance, Managing Service Quality 13 (1): 27-38.

Mao, X.; Li, Z. 2010. Agent based affective tutoring systems: A pilot study, Computers \& Education 55(1): 202-208.

Marsh, H. W.; Overall, J. U.; Kesler, S. P. 1979. Validity of student evaluations of instructional effectiveness: A comparison of faculty self-evaluations and evaluations by their students, Journal of Educational Psychology 71(2): 149-160.

Matsuno, S. 2009. Self-, peer-, and teacher-assessments in Japanese university EFL writing classrooms, Language Testing 26(1): 75-100.

McCarthy, J. 1959. Programs with common sense, in Proc. of The Teddington Conference on the Mechanization of Thought Processes. London: Her Majesty's Stationery Office, 75-91. 
Minsky, M. 1981. A framework for representing knowledge, in D. Metzing (Ed.), Frame conceptions and text understanding. New York: Gruyter, 1-25.

Moffat, S.; Kohler, N. 2008. Conceptualizing the built environment as a socialecological system, Building Research \& Information 36(3): 248-268.

Mynttinen, S.; Sundstrõm, A.; Vissers, J.; Koivukoski, M.; Hakuli, K.; Keskinen, E. 2009. Self-assessed driver competence among novice drivers a comparison of driving test candidate assessments and examiner assessments in a Dutch and Finnish sample, Journal of Safety Research 40(4): 301-309.

Newell, A.; Shaw, J.; Simon, H. 1956. Empirical explorations of the logic theory machine, in Proc. of The Western Joint Computer Congress, 218-239.

Nick, M.; Becker, M. 2007. A hybrid approach to intelligent living assistance, in The Seventh International Conference on Hybrid Intelligent Systems, Kaiserslautern, Germany, 2007, 283-289.

Nishioka, T.; Ohtaka, K.; Hashimoto, N.; Onojima, H. 2000. Measurement and evaluation of the indoor thermal environment in a large domed stadium, Energy and Buildings 32(2): 217-223.

Noftle, E. E.; Robins, R. W. 2007. Personality predictors of academic outcomes: Big Five correlates of GPA and SAT scores, Journal of Personality and Social Psychology 93(1): 116-130.

Nonaka, I.; Takeuchi, H. 1995. The Knowledge Creating Company: How Japanese Companies Create the Dynamics of Innovation. Oxford University Press. 304 p.

Nwana, H. S. 1990. Intelligent tutoring systems: an overview. Artificial Intelligence Review 4(4): 251-277.

Ochoa, C. E.; Capeluto, I. G. 2008. Strategic decision-making for intelligent buildings: comparative impact of passive design strategies and active features in a hot climate, Building and Environment 43(11): 1829-1839.

Ogunlana, S.; Siddiqui, Z.; Yisa, S.; Olomolaiye, P. 2002. Factors and procedures used in matching project managers to construction projects in Bangkok, International Journal of Project Management 20(5): 385-400.

Omer, A. M. 2008. Renewable building energy systems and passive human comfort solutions, Renewable and Sustainable Energy Reviews 12(6): 1562-1587.

Papinczak, T.; Young, L.; Groves, M.; Haynes, M. 2007. An analysis of peer, self, and tutor assessment in problem-based learning tutorials, Medical Teacher 29: 122-132.

Park, J. H.; Park, H. S.; Lee, S. J.; Choi, J.; Lee, D. G. 2005. Intelligent multimedia service system based on context awareness in smart home, Lecture Notes in Computer Science 3681: 1146-1152.

Pekrun, R.; Frenzel, A. C.; Goetz, T.; Perry, R. P. 2007. The control value theory of achievement emotions: an integrative approach to emotions in education, in P. A. Shutz, R. Pekrun (Eds.), Emotion in Education. Academic Press, 13-36. 
Podvezko, V. 2011. The Comparative Analysis of MCDA Methods SAW and COPRAS, Inzinerine Ekonomika-Engineering Economics 22(2): 134-146.

Popescu, E. 2010. Adaptation provisioning with respect to learning styles in a Webbased educational system: an experimental study, Journal of Computer Assisted Learning 26: 243-257.

Pouliquen, B.; Le Duff, F.; Delamarre, D.; Cuggia, M.; Mougin, F.; Le Beux, P. 2005. Managing Educational Resource in Medicine: System Design and Integration, International Journal of Medical Informatics 74(2-4): 201-207.

Ríos-Moreno, G. J.; Trejo-Perea, M.; Castañeda-Miranda, R.; Hernández-Guzmán, V. M.; Herrera-Ruiz, G. 2007. Modelling temperature in intelligent buildings by means of autoregressive models, Automation in Construction 16(5): 713-722.

Ruch, P.; Boyer, C.; Chichester, C.; Tbahriti, I.; Geissbühler, A.; Fabry, P.; Gobeill, J.; Pillet, V.; Rebholz-Schuhmann, D.; Ovis, C. 2007. Using Argumentation to Extract Key Sentences from Biomedical Abstracts, International Journal of Medical Informatics 76(2-3): 195-200.

Ruiz, M. C.; Romero, E.; Pérez, M. A.; Fernández, I. 2012. Development and application of a multi-criteria spatial decision support system for planning sustainable industrial areas in Northern Spain, Automation in Construction 22: 320-333.

Rutter, M; Maughan, B. 2002. School effectiveness findings 1979-2002, Journal of School Psychology 40(6): 451-475.

Saa, R.; Garcia, A.; Gomez, C.; Carretero, J.; Garcia-Carballeira, F. 2012. An ontologydriven decision support system for high-performance and cost-optimized design of complex railway portal frames, Expert Systems with Applications 39(10): 8784-87.

Sarkis J.; Meade L.; Presley A. 2008. Sustainability in the built environment: factors and a decision framework, in The 39th Annual Meeting of the Decision Sciences Institute, Proceedings, 2581-2586.

Sarrafzadeh, A.; Alexander, S.; Dadgostar, F.; Fan, C.; Bigdeli, A. 2008. "How do you know that I don't understand?" A look at the future of intelligent tutoring systems, Computers in Human Behavior 24(4): 1342-1363.

Schacht, K. 2004. New developments: smart materials (cutting edge, shape-memory properties, column), Appliance Manufacturer 52(1): 14-16.

Simanavičienè, R. 2011. The sensitivity analysis of the quantitative multiple attribute decision making methods: summary of doctoral dissertation. Vilnius: Technika. 24 p.

Siemer, J.; Angelides, M. C. 1998. A comprehensive method for the evaluation of complete intelligent tutoring systems, Decision support systems 22(1): 85-102.

Sleeman, D.; Brown, J. S. 1982. Introduction: Intelligent Tutoring Systems, in D. Sleeman, J. S. Brown (Eds.) Intelligent Tutoring Systems. New York: Academic Press, 1-11.

Staedter, T. 2003. The smart antenna, Technology Review Cambridge 106(1): 81-82. 
Stankov, S.; Rosić, M.; Žitko, B.; Grubišić, A. 2008. TEx-Sys model for building intelligent tutoring systems, Computers \& Education 51(3): 1017-1036.

Sundström, A. 2008. Self-assessment of driving skill - A review from a measurement perspective, Transportation Research Part F: Traffic Psychology and Behavior 11(1): $1-9$.

Sung, Y. T.; Chang, K. E.; Chiou, S. K.; Hou, H. T. 2005. The design and application of a web-based self- and peer-assessment system, Computers \& Education 45(2): 187-202.

Sung, Y.; Chang, K.; Chang, T.; Yu, W. 2009. How many heads are better than one? The reliability and validity of teenagers' self- and peer- assessments, Journal of Adolescence 33(1): 135-145.

Suppes, P. 1967. Some theoretical models for mathematics learning, Journal of Research and Development in Education 1: 5-22.

Tong, A. K.; Angelides, M. C. 2000. An empirical model for tutoring strategy selection in multimedia tutoring systems, Decision Support Systems 29(1): 31-45.

Trnkoczy, J.; Turk, Z.; Stankovski, V. 2006. A Grid-Based Architecture for Personalized Federation of Digital Libraries, Library Collections, Acquisitions, and Technical Services 30(3-4): 139-153.

Tupènaité, L. 2010b. Multiple criteria assessment of built and human environment renovation projects. Vilnius: Technika. 129 p.

Uhr, L. 1969. Teaching machine programs that generate problems as a function of interaction with students, Proceedings of the 24th National Conference, New York, USA, $1969,125-134$.

Urban-Lurain, M. Intelligent Tutoring Systems: An Historic Review in the Context of the Development of Artificial Intelligence and Educational Psychology [online], Available from Internet: <http://www.cse.msu.edu/rgroups/cse101/ITS/its.htm>. [accessed 2303 2010].

Wang, J. 2003. A Knowledge Network Constructed by Integrating Classification, Thesaurus, and Metadata in Digital Library, The International Information \& Library Review 35(2-4): 383-397.

Wang, J. T. 2010. Pupil Dilation and Eye-Tracking, in M. Schulte-Mecklenbeck, A. Kuhberger, R. Ranyard (Eds.), A Handbook of Process Tracing Methods for Decision Research: A Critical Review and User's Guide. Psychology Press, 185-204.

Wong, J. K. W.; Li, H.; Wang, S. W. 2005. Intelligent building research: a review, Automation in Construction 14(1): 143-159.

Wong, J.; Li, H.; Lai, J. 2008. Evaluating the system intelligence of the intelligent building systems: Part 1: development of key intelligent indicators and conceptual analytical framework, Automation in Construction 17(3): 284-302.

Wood, B. 2006. The role of existing buildings in the sustainability agenda, Facilities 24(1/2): 61-67. 
Wood, G.; Newborough, M. 2007. Energy-use information transfer for intelligent homes: enabling energy conservation with central and local displays, Energy and Buildings 39(4): 495-503.

Xiao, Y.; Lucking, R. 2008. The impact of two types of peer assessment on students' performance and satisfaction within a Wiki environment, The Internet and Higher Education 11(3-4): 186-193.

Zavadskas, E. K.; Kaklauskas, A. 1996a. Pastatu sistemotechninis įvertinimas. Vilnius: Technika. $280 \mathrm{p}$.

Zavadskas, E. K.; Kaklauskas, A. 1996b. Determination of an efficient contractor by using the new method of multicriteria assessment, in The International Symposium for "The Organisation and Management of Construction". Shaping Fhery and Practice. Vol 2. Managing the Construction Project and Managing Risk, 94-104.

Zavadskas, E. K.; Kaklauskas, A. 1999. A new method of complex evaluation of projects based on multiple criteria analysis and the principle of proportionality, in $\mathrm{D}$. K. Despotis, C. Zopounidis (Eds.), Integrating Technology and Human Decisions: Global Bridges in to the 21st Century, Proceedings of the Fifth International Conference. Vol. 2, 2051-2053.

Zavadskas, E. K.; Kaklauskas, A.; Banaitis, A.; Kvederyte, N. 2004. Housing credit access model: the case for Lithuania, European Journal of Operation Research 155(2): $335-352$.

Zavadskas, E. K.; Kaklauskas, A.; Vainiunas, P.; Gikys, M. 2000b. Property management in postgraduate Internet studies in Vilnius Gediminas Technical University, in The 4th Baltic region Seminar on Engineering Education, Lyngby, Copenhagen, Denmark, 2000. Seminar Proceedings, 83-86.

Zavadskas, E. K.; Kaklauskas, A.; Vlasenko, A. 2008d. Web-based VSA analyser decision support system for e-examination, in Proc. of the 8th international FLINS conference "Computational intelligence in decision and control", 21-24 September, 2008, Madrid, Spain. Vol. 1, 1153-1158.

Zavadskas, E. K.; Kaklauskas, A; Turskis, Z.; Tamošaitienė, J. 2008a. Selection of the effective dwelling house walls by applying attributes values determined at intervals, Journal of Civil Engineering and Management 14(2): 85-93.

Zavadskas, E. K.; Kaplinski, O.; Kaklauskas, A.; Brzezinski, J. 1995. Expert systems in construction. Trends, potential \& applications. Vilnius: Technika. 180 p.

Zavadskas, E. K.; Peldschus, F.; Kaklauskas, A. 1994. Multiple criteria evaluation of projects in construction. Vilnius: Technika. $226 \mathrm{p}$.

Zavadskas, E. K.; Turskis, Z. 2011. Multiple criteria decision making (MCDM) methods in economics: an overview, Technological and Economic Development of Economy 17(2): 397-427.

Zavadskas, E. K.; Turskis, Z.; Tamošaitienė, J.; Marina, V. 2008b. Multicriteria selection of project managers by applying grey criteria, Technological and Economic Development of Economy 14(4): 462-77. 
Zavadskas, E.; Kaklauskas, A. 2000a. Efficiency increase in research and studies while applying up-to-date information technologies, Journal of Civil Engineering and Management 6(6): 397-414.

Zimmerman, B.; Kitsantas, A. 2007. Reliability and validity of Self-Efficacy for Learning Form (SELF) scores of college students, Zeitschrift für Psychologie 215(3): 157163. 



\section{The List of Scientific Author's Publications on the Subject of the Dissertation}

\section{In the reviewed scientific periodical publications}

Kaklauskas, A.; Zavadskas, E. K.; Pruskus, V.; Vlasenko, A.; Seniut, M.; Kaklauskas, G.; Matuliauskaite, A.; Gribniak, V. 2010a. Biometric and Intelligent Self-Assessment of Student Progress System, Computers and Education 55(2): 821-833.

Kaklauskas, A.; Zavadskas, E. K.; Seniut, M.; Dzemyda, G.; Stankevic, V.; Simkevičius, C.; Stankevic, T.; Paliskiene, R.; Matuliauskaite, A.; Kildiene, S.; Bartkiene, L.; Ivanikovas, S.; Gribniak, V. 2011a. Web-based biometric computer mouse advisory system to analyze a users emotions and work productivity, Engineering Applications of Artificial Intelligence 24(6): 928-945.

Kaklauskas, A.; Vlasenko, A.; Raudonis, V.; Zavadskas, E. K.; Gudauskas, R.; Seniut, M.; Juozapaitis, A.; Jackute, I.; Kanapeckiene, L.; Rimkuviene, S.; Kaklauskas, G. 2012. Student progress assessment with the help of an intelligent pupil analysis system, Engineering Applications of Artificial Intelligence. http://dx.doi.org/10.1016/j.engappai.2012.01.006.

Kaklauskas A.; Zavadskas E. K.; Seniut M.; Vlasenko A.; Kaklauskas G.; Juozapaitis A.; Matuliauskaite A.; Kaklauskas G.; Zemeckyte L.; Jackute I. 2013. Biometric and 
Intelligent Student Progress Assessment System, Advanced Methods for Computational Collective Intelligence 457: 59-69. DOI: 10.1007/978-3-642-34300-1_6.

Kanapeckienè, L.; Kaklauskas, A.; Zavadskas, E. K.; Seniut, M. 2010. Integrated knowledge management model and system for construction projects, Engineering Applications of Artificial Intelligence 23(7): 1200-1215.

Tupènaitè, L.; Zavadskas, E. K.; Kaklauskas, A.; Turskis, Z.; Seniut, M. 2010a. Multiple criteria assessment of alternatives for built and human environment renovation, Journal of Civil Engineering and Management 16(2): 257-266.

Urbanavičienė, V.; Kaklauskas, A.; Zavadskas, E. K.; Seniut, M. 2009. The web-based real estate multiple criteria negotiation decision support system: a new generation of decision support systems, International Journal of Strategic Property Management 13(3): 267-286.

\section{In other editions (ISI Proceedings)}

Kaklauskas, A.; Zavadskas, E. K.; Babenskas, E.; Seniut, M.; Vlasenko, A.; Plakys, V. 2007b. Intelligent library and tutoring system for Brita in the PuBs project, in Cooperative design, visualization, and engineering 4th international conference (CDVE 2007), 16-20 September, 2007, Shanghai, China. Lecture Notes in Computer Science 4674: $157-166$.

Kaklauskas, A.; Zavadskas, E. K.; Seniut, M.; Krutinis, M.; Dzemyda, G.; Ivankovas, V.; Stankevič, V; Šimkevičius, Č; Jaruševičius, A. 2008c. Web-based biometric mouse decision support system for user's emotional and labour productivity analysis, in Proc. of The 25th International Symposium on Automation and Robotics in Construction (ISARC 2008): selected papers, 26-29 June, 2008, Vilnius, Lithuania, 69-75.

Kaklauskas, A.; Vlasenko, A.; Seniut, M.; Krutinis, M. 2009a. Voice stress analyser system for E-testing, in Proc. of The 9th IEEE international conference on advanced learning technologies, 15-17 July, 2009 Riga, Latvia, 693-695.

Kaklauskas, A.; Krutinis, M.; Seniut, M. 2009b. Biometric mouse intelligent system for student's emotional and examination process analysis, in Proc. of The 9th IEEE international conference on advanced learning technologies, 15-17 July, Riga, Latvia, 189193.

Zavadskas, E. K.; Kaklauskas, A.; Seniut, M.; Dzemyda, G.; Ivankovas, V.; Stankevič, V.; Šimkevičius, Č.; Jaruševičius, A. 2008c. Web-based biometric mouse intelligent system for analysis of emotional state and labour productivity, in The 25th International Symposium on Automation and Robotics in Construction (ISARC 2008), 26-29 June, 2008. Vilnius: Technika. Selected papers, 429-434. 


\section{Patents registered in Lithuania}

Krutinis, M. Elektroninès informacijos paieškos būdas ir sistema: patentas / išradèjai: A. Kaklauskas, E. K. Zavadskas, M. Seniut, P. Vainiūnas, M. Krutinis, L. Tupènaitè. Vilnius, 2010. Prieiga per internetą: http://lt.espacenet.com. 
DEVELOPMENT OF THE INTELLIGENT TUTORING SYSTEM FOR BUILT ENVIRONMENT

Doctoral Dissertation

Technological Sciences,

informatics engineering (07T)

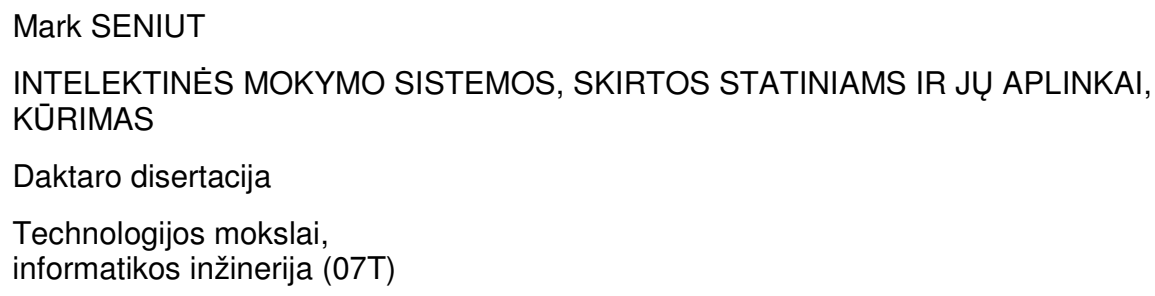

